\title{
New taxa and combinations in Eucalyptus and Angophora (Myrtaceae)
}

\author{
L.A.S. Johnson \& K.D. Hill
}

\begin{abstract}
Johnson, L.A.S. \& Hill, K.D. (National Herbarium of New South Wales, Royal Botanic Gardens, Sydney, Australia 2000) 1990. New taxa and combinations in Eucalyptus and Angophora (Myrtaceae). Telopea 4(1): 37-108. A number of new taxa are described at specific and subspecific rank, and other taxa are changed in status. New species are Angophora robur, Eucalyptus brunnea, E. scias (with three subspecies, subspp. scias, apoda and callimastha), E. interstans, E. prava, E. nandewarica, E. retinens, E. volcanica, E. nobilis, E. triplex, E. ophitica, E. hypostomatica, E. magnificata, E. placita, E. ancophila, E. apothalassica, E. psammitica, E. stannicola, E. williamsiana, E. subtilior, E. bensonii, E. conjuncta, E. croajingolensis and E. olida. New subspecies are described in E. camphora (subspp. relicta and humeana), E. coolabah (subsp. excerata), E. populnea (subsp. bimbil), E. polyanthemos (subsp. vestita), E. paniculata (subsp. matutina), E. fergusonii (subsp. dorsiventralis), and E. robertsonii (subsp. hemisphaerica). Taxa newly recognised at specific rank are Angophora euryphylla, A. crassifolia, Eucalyptus aquatica, E. elliptica, E. dorrigoensis, and E. latiuscula. Previously described species newly reinstated from synonymy are E. praecox, E. coolabah, E. sparsifolia, E. robertsonii, and E. fergusonii. Infraspecific taxa are reinstated and are treated as subspecies in E. resinifera (subsp. hemilampra), E. amplifolia (subsp. sessiliflora), E. coolabah (subsp. $a$ arida), and $E$. radiata (subsp. sejuncta, a new name for $E$. radiata var. subplatyphylla). Lectotypes are designated for E. camphora, E. lactea $(=E$. praecox), E. dorrigoensis, E. coolabah, E. coolabah var. arida, E. ovalifolia var. lanceolata (=E. polyanthemos subsp. polyanthemos), $E$. nanglei (= $E$. paniculata subsp. paniculata), E. fergusonii, E. phellandra (= E. radiata subsp. radiata), E. australiana $(=$ E. radiata subsp. radiata), E. radiata var. subexserta ( $=E$. radiata subsp. radiata), and $E$. radiata var. subplatyphylla $(=E$. radiata subsp. sejuncta). A new name $E$. beyeriana is provided for the taxon previously known as $E$. beyeri, the type of the latter being of hybrid origin.
\end{abstract}

\section{Introduction}

Recent studies in eucalypt systematics have brought to light a surprisingly large number of undescribed taxa (Brooker 1988, Brooker \& Hopper in press). The taxa included here are a small selection of a large number that have been defined during an overall revision of the eucalypts (in progress). These are taxa occurring in New South Wales, which we need to publish in advance in order to validate names for use in the forthcoming second volume of the Flora of New South Wales. Additional new species from New South Wales are also being described by Johnson \& Blaxell (in prep.). At this stage, Eucalyptus L'Hérit. and Angophora Cav. will be used in the traditional sense. The species are not allocated alphabetic codes according to the system of Pryor \& Johnson (1971), since these are being completely revised. Species are treated in the order in which they occur in the revised classification developed from Pryor \& Johnson during this work. We are acquainted with all the taxa and their relatives in the field.

Rare or threatened species are allocated conservation status codes according to the system of Briggs \& Leigh (1988).

\section{Terminology}

The term 'stemonophore' is used throughout as a more acceptable Greek combination 
than the Latin-Greek hybrid 'staminophore' (after Johnson \& Briggs 1984).

The term 'calyptra' is used throughout in place of 'operculum' as traditionally used in Eucalyptus. The latter term has been used in Eucalyptus alone, whereas the former is the accepted term for the broadly homologous fused perianth structures occurring widely in Myrtaceae (Johnson \& Briggs 1984, following McVaugh 1968).

The calyptra in all Monocalyptus taxa is described as 'appearing single' in reference to the actually complex nature and origin of this structure, to be discussed elsewhere.

Bark is described as 'persistent' in cases where it is not regularly shed, and 'smooth' when regularly shedding. The former includes 'stringybark', 'box' and 'ironbark' among other types, and the latter covers the 'gum' barks.

1. Angophora euryphylla (L. Johnson ex G. Leach) L. Johnson \& K. Hill, comb. et stat. nov.

BASIONYM: Angophora costata (Gaertn.) Britten subsp. euryphylla L. Johnson ex G. Leach, Telopea 2(6): 759 (1986).

Type Citation: 'Holotype: New South Wales: Central Coast: 3 km NW. of Gibbs Place, Putty, Pickard 1639, 26.4.1971 (NSW).'

Tree to $25 \mathrm{~m}$ high. Bark smooth, shedding in small scales, pink, grey or cream. Juvenile leaves ovate or narrowly triangular, sessile, cordate, to $10 \mathrm{~cm}$ long, $4.5 \mathrm{~cm}$ wide. Intermediate leaves ovate, petiolate, cordate, to $20 \mathrm{~cm}$ long, $9 \mathrm{~cm}$ wide, setose in young coppice shoots. Adult leaves broad-lanceolate, $12-19 \mathrm{~cm}$ long, 2-4.5 cm wide; petiole 15-20 mm long. Peduncle 15-25 mm long, setose; pedicel 8-15 mm long, setose. Buds ovoid, 6-10 mm long, 6-11 mm diam. Petals 4-5 mm long, 5-6 mm wide. Hypanthium strongly ribbed. Fruit ovoid, 15-21 mm long, 14-20 mm diam.; disc depressed.

Distinguished from $A$. costata (Gaertn.) Britten by the larger fruit (to $17 \mathrm{~mm}$ long and diam. in $A$. costata), the longer pedicel (to $8 \mathrm{~mm}$ long in $A$. costata), the setose coppice leaves, and the broad-lanceolate adult leaves. The two are parapatric in the area of occurrence of $A$. euryphylla, and although a degree of intergradation occurs, the two retain their identities and are considered to be reproductively separated.

Selected SPECimens (from 10 examined): NeW South Wales: Central Coast: Old Convict Road, $20.1 \mathrm{~km}$ E of Howes Valley, J. Campbell \& J. Pickard 1199, 26.7.1970 (NSW); Old Convict Road, $5.5 \mathrm{~km}$ due $\mathrm{W}$ of Paynes Crossing, K. Hill 2784 \& L. Stanberg, 3.5 .1988 (NSW, PERTH, BRI); 1 mile [1.6 km] N of Gibbs Long Swamp, NNW of Putty, L.A.S. Johnson NSW 127674, 14.11.1965 (NSW); Judge Dowling Range, 8 miles [12.8 km] NNW of Kulnura, L.A.S. Johnson NSW 143619, 17.10.1965 (NSW).

DISTRIBUTION: Restricted to a small area between Putty and Wollombi, and south along the Judge Dowling Range (Figure 1).

ECOLOGY: Locally frequent in closed woodland on shallow or skeletal soils on sandstone ridges.

CONSERVATION STATUS: Not considered to be at risk. Although distributed over a limited area, this species is locally abundant and much of the range lies within national parks and reserves.

2. Angophora crassifolia (G. Leach) L. Johnson \& K. Hill, comb. et stat. nov.

BASIONYM: Angophora bakeri C. Hall subsp. crassifolia G. Leach, Telopea 2(6): 766 (1986).

Type Citation: 'Holotype: New South Wales: Central Coast: past St Ives towards 
Terrey Hills on the Mona Vale road, Leach 122, 21 May 1975 (LTB). IsOTYPES: CANB, NSW, BRI, MEL.'

Tree to $15 \mathrm{~m}$ high. Bark persistent, grey, shortly fibrous. Juvenile leaves lanceolate, to 8.5 cm long, $3 \mathrm{~cm}$ wide. Adult leaves lanceolate, $7-11 \mathrm{~cm}$ long, $0.7-1.5 \mathrm{~cm}$ wide; petiole 6-10 mm long. Peduncle 15-25 mm long, usually setose; pedicel 10-15 mm long, usually setose. Buds globose, 5-6 mm long, 6-8 mm diam. Petals 3-4 mm long, 3-4 $\mathrm{mm}$ wide. Hypanthium smooth or slightly ribbed. Fruit ovoid, usually apically narrowed, 10-14 mm long, 9-14 $\mathrm{mm}$ diam.; disc flat, obscured by rim of hypanthium.

Distinguished from $A$. bakeri $\mathrm{C}$. Hall by the coriaceous, lanceolate adult leaves, the lanceolate juvenile leaves, and the larger fruit (to $11 \mathrm{~mm}$ long, $12 \mathrm{~mm}$ diam. in $A$. bakeri) with longer pedicels (to $11 \mathrm{~mm}$ long in $A$. bakeri). The two taxa are allopatric, with no known interbreeding.

SELECTED SPECIMENS (from 18 examined): NEW SOUTH WALES: Central Coast: Tumbledown Dick, W.F. Blakely \& J.L. Boorman NSW 143467, 14.2.1922 (NSW); 1 mile E of St Ives Showground, M.I.H. Brooker 3312, 28.12.1971 (CANB, NSW); Frenchs Forest, C. Burgess B316, 27.12.1973 (CBG, NSW); 1 mile SE of Killara railway station, W.F. Blakely, 18.7.1936 (NSW 143577); Castlecove, Ridge N of Sugarloaf Bay, L.A.S. Johnson NSW 143474, 8.7.1950 (NSW); Northbridge, E end of Upper Cliff Avenue, L.A.S. Johnson 9044, 30.12.1987 (CANB, NSW, PERTH).

Distribution: Restricted to the Ku-ring-gai Plateau region, between Port Jackson and the Hawkesbury River (Figure 1).

ECOLOGY: Locally frequent, usually associated with remnants of Tertiary lateritic soils over siliceous Hawkesbury Sandstone.

CONSERVATION STATUS: 2VCa. Large populations of this species occur in Ku-ring-gai Chase National Park and nearby reserves, but their proximity to the Sydney metropolitan region means that these must be considered to be vulnerable.

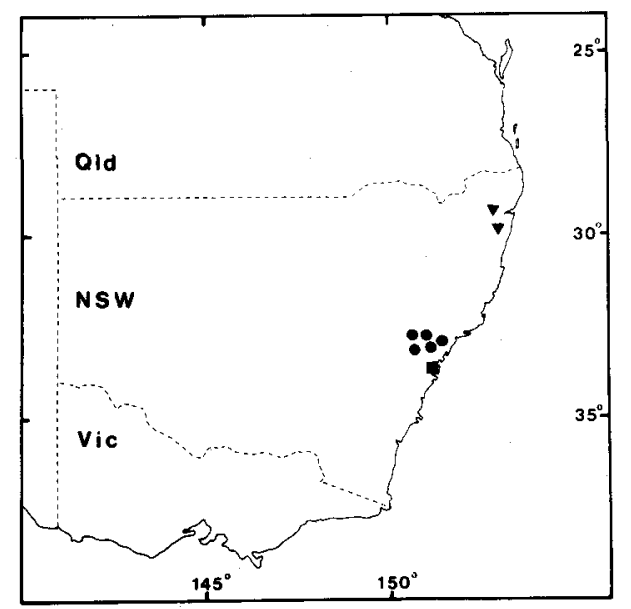

Figure 1. Distribution of A. euryphylla (circle), A. crassifolia (square) and A. robur (triangle). 
3. Angophora robur L. Johnson $\mathcal{E}$ K. Hill, sp. nov.

$\mathrm{Ab}$ A. subvelutina foliis alabastris fructibusque majoribus et pedicellis longioribus distinguitur.

TYPE: New SOUTH WALES: North Coast: $1.3 \mathrm{~km} \mathrm{~N}$ of Kremnos Creek on Glenreagh-Grafton road, K. Hill 787 \& L. Johnson, 7.5.1984 (holo NSW).

Tree to $10 \mathrm{~m}$ high. Bark persistent throughout, grey, shortly fibrous. Juvenile leaves narrow-oblong, to $10 \mathrm{~cm}$ long, $2 \mathrm{~cm}$ wide. Adult leaves broad-lanceolate to ovate, cordate, apically acute or acuminate, scabrid with short bristle glands, $7-18 \mathrm{~cm}$ long, 3-7.5 cm wide; petiole $0-1 \mathrm{~mm}$ long. Peduncle $15-35 \mathrm{~mm}$ long, setose; pedicel 7-15 $\mathrm{mm}$ long, setose. Buds globose, c. $10 \mathrm{~mm}$ long, $10 \mathrm{~mm}$ diam. Hypanthium ribbed. Fruit ovoid or campanulate, sometimes apically narrowed, $12-16 \mathrm{~mm}$ long, $12-16 \mathrm{~mm}$ diam.; disc flat, often obscured by rim of hypanthium.

A. robur is distinguished from $A$. subvelutina $\mathrm{F}$. Muell. by the much larger adult leaves, buds and fruit (adult leaves to $9 \mathrm{~cm}$ long, $4 \mathrm{~cm}$ wide, buds to $7 \times 7 \mathrm{~mm}$, fruit to $11 \mathrm{X}$ $11 \mathrm{~mm}$ in A. subvelutina). A. robur is also generally a smaller, more gnarled and twisted tree than $A$. subvelutina. Leaves, buds and fruit resemble those of $A$. hispida (Sm.) Blaxell in gross features of size and shape. The latter however has thicker leaves with more strongly differentiated upper and lower surfaces and rounded apices, and a thinner, more scaly bark. The habit is also more that of a shrub or mallee, whereas $A$. robur is always clearly a tree with a well-defined bole. Intergrades occur with $A$. subvelutina and $A$. woodsiana Bailey where ranges adjoin.

Selected SPECIMENS (from 5 examined): New South WALES: North Coast: $6 \mathrm{~km} \mathrm{~S}$ of Halfway Creek on Pacific Highway, D.F. Blaxell 1850 \& L.A.S. Johnson, 22.4.1981 (NSW); $2 \mathrm{~km}$ E of Copmanhurst on Grafton road, K. Hill $794 \mathcal{E}$ L. Johnson, 7.5.1984 (NSW); $6.7 \mathrm{~km} \mathrm{~N}$ of Glenreagh on Grafton road, M.I.H. Brooker 6101, 25.1.1979 (CANB, NSW).

DISTRIBUTION: Locally frequent but restricted, occurring sporadically in a band of country running from north-west of Coffs Harbour, around Glenreagh, to north-west of Grafton, in the Coaldale district (Figure 1).

ECOLOGY: Restricted to dry sclerophyll woodland on shallow or skeletal soils on highly siliceous sandstone phases of the Cretaceous Grafton Formation.

The epithet is from the Latin robur, 'an oak-tree' (one sense of the Latin word), referring to the appearance of the spreading trees of this broad-leaved species.

CONSERVATION STATUS: 3V-. The poor sandstone outcrop habitat of this species would not be under immediate direct threat from pastoral activity.

\section{Eucalyptus brunnea L. Johnson \& K. Hill, sp. nov.}

$\mathrm{Ab} E$. deanei characteribus sequentibus differt: folia nitidiora maculis grandibus distinctioribusque abaxialiter instructa.

TYPE: New South Wales: Northern Tablelands: $2.3 \mathrm{~km}$ N of Torrington on Silent Grove road, $R$. Coveny 5192, 7.9.1973 (holo NSW).

Tree to $35 \mathrm{~m}$ high. Bark smooth, grey, yellow, orange or brown, shedding in broad, short ribbons, with a persistent scaly stocking to 1-2 m. Seedling leaves opposite for 4-6 nodes, petiolate. Juvenile leaves disjunct, ovate to orbicular, to $7 \mathrm{~cm}$ long, $7 \mathrm{~cm}$ wide; petioles to $1.1 \mathrm{~cm}$ long. Adult leaves disjunct, strongly dorsiventral, glossy dark green above, dull, pale, with distinct clusters of brown epidermal cells beneath, lanceolate to ovate, acute or acuminate, $7-14 \mathrm{~cm}$ long, $1.4-6.0 \mathrm{~cm}$ wide; petioles to $2.6 \mathrm{~cm}$ long; lateral veins closely to moderately spaced, regular, at $40-60^{\circ}$ to midrib; reticulum even; oil glands large, closely spaced; intramarginal vein distinct, continuous, $0.5-2.0 \mathrm{~mm}$ 
from margin. Inflorescences simple, axillary; umbellasters 7 -flowered; peduncles terete or flattened, 7-14 mm long; pedicels terete, 2-5 $\mathrm{mm}$ long. Mature buds clavate, 6-8 $\mathrm{mm}$ long, 3-5 mm diam. Calyptra double, outer shed early, inner hemispherical, minutely apiculate, about half as long as hypanthium. Fruit cup-shaped, 3- rarely 4locular, 5-7 mm long, 4-6 mm diam.; calyptra scar vertical, c. $0.5 \mathrm{~mm}$ wide; stemonophore raised, forming an elevated ridge around top of fruit, c. $0.5 \mathrm{~mm}$ wide; disc depressed at $20-70^{\circ}$, ultimately incurved, c. 1-2 mm wide; valves triangular, acute, basally enclosed, apically rim-level, raised at $60-90^{\circ}$.

$E$. brunnea differs from $E$. deanei Maiden in the more glossy adult and juvenile leaves with distinct brown epidermal markings abaxially, and the seasonally stronglycoloured brown bark (i.e. at certain stages in the shedding cycle). Juvenile leaves are more frequently orbicular and apically rounded, while those of $E$. deanei are more ovate, usually with a 'drip-tip'. Buds and fruit tend to have shorter, thicker pedicels and the calyptra is slightly shorter in E. brunnea.

SELECTED SPECIMENS (from 29 examined): QUEENSLAND: about E of Tannymorel on western slopes of Main Range, S.T. Blake 19224, 16.9.1953 (AAU, B, BISH, BRI, CANB, CHR, K, L, LE, MO, NSW, PR, PRE, SP); Thulimbah, J.H. Simmonds, 1.11.1910 (NSW); near South Bald Rock, 8 km ENE of Wallangarra, L. Pedley A7414, 21.2.1974 (NSW, BRI); Bald Rock ( $28^{\circ} 51^{\prime}$ S $152^{\circ} 02^{\prime} \mathrm{E}$ ), M.D. Crisp 2529, 24.5.1977 (CBG, NSW). NEW South WALES: Northern Tablelands: 9.1 miles [14.5 km] from Tenterfield towards Bald Rock, M.I.H. Brooker 3949, 2.3.1973 (CANB, NSW); Tenterfield to Sandy Flat, J.H. Maiden, 12.1898 (NSW); 19 miles [30.4 km] NE of Glen Innes, D.J. McGillivray 2390 \& L. Johnson, 20.9 .1966 (NSW).

Distribution: New South Wales, north-eastern Northern Tablelands, from Wallangarra to Torrington and Ebor. Queensland, south-eastern Darling Downs, around Wallangarra (Figure 2).

ECOLOGY: Sporadic and scattered, locally abundant, in tall wet sclerophyll forests on wetter, sheltered sites and deeper, richer soils. Often associated with $E$. caliginosa Blakely, E. radiata Sieber ex DC. subsp. sejuncta L. Johnson \& K. Hill and E. andrewsii Maiden or E. campanulata R. Baker \& H.G. Smith.

The epithet is from the Late Latin brunneus, 'brown', in reference to the frequently brownish bark, and the vernacular name Brown Gum sometimes used for the species.

CONSERVATION STATUS: Not considered to be at risk.

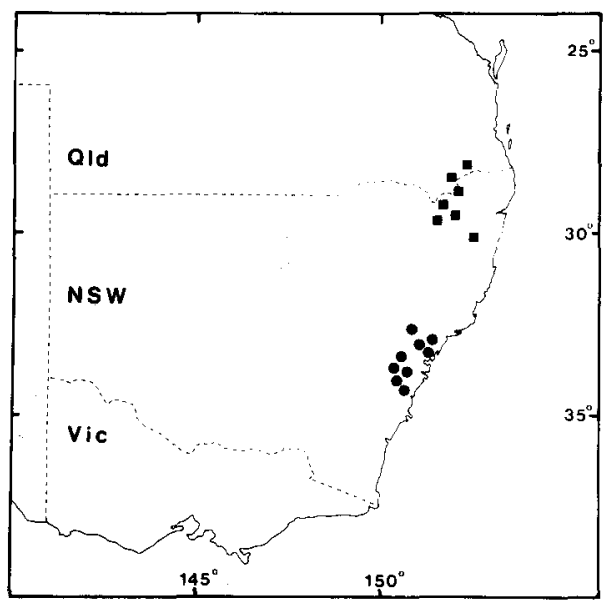

Figure 2. Distribution of E. brunnea (square) and E. deanei (circle). 
5. Eucalyptus scias L. Johnson \& K. Hill, sp. nov.

$\mathrm{Ab}$ E. pellita characteribus sequentibus differt: folia adulta minora angustiora et distinctius dorsiventralia; pedicelli plerumque breviores; cortex fibrosior quasi 'stringybark' simulans.

TYPE: New SOUTH WALES: Central Coast: West Head, Ku-ring-gai Chase National Park (333'ㄴ, $\left.151^{\circ} 18^{\prime} \mathrm{E}\right)$ M.I.H. Brooker 3039 (FRI 20741), 5.5.1971 (holo NSW; iso CANB).

Tree to $20 \mathrm{~m}$ high, or mallee in exposed situations. Bark persistent throughout, fibrous, dark red-brown. Seedling leaves opposite for 3-5 nodes, lanceolate, petiolate. Juvenile leaves disjunct, broad-lanceolate to ovate, to $16 \mathrm{~cm}$ long, $10 \mathrm{~cm}$ wide; petioles to $2 \mathrm{~cm}$ long. Adult leaves disjunct, strongly dorsiventral, lanceolate, 7-15 cm long, $1.3-3.2 \mathrm{~cm}$ wide; petioles to $2.2 \mathrm{~cm}$ long; lateral veins closely spaced, regular at $50-70^{\circ}$ to midrib; reticulum even; intramarginal vein distinct, continuous, $0.5-1.5 \mathrm{~mm}$ from margin. Inflorescences simple, axillary; umbellasters 3-7-flowered; peduncles flattened, 5-23 $\mathrm{mm}$ long, to $7 \mathrm{~mm}$ wide apically; pedicels angular or flattened, $0-9 \mathrm{~mm}$ long. Mature

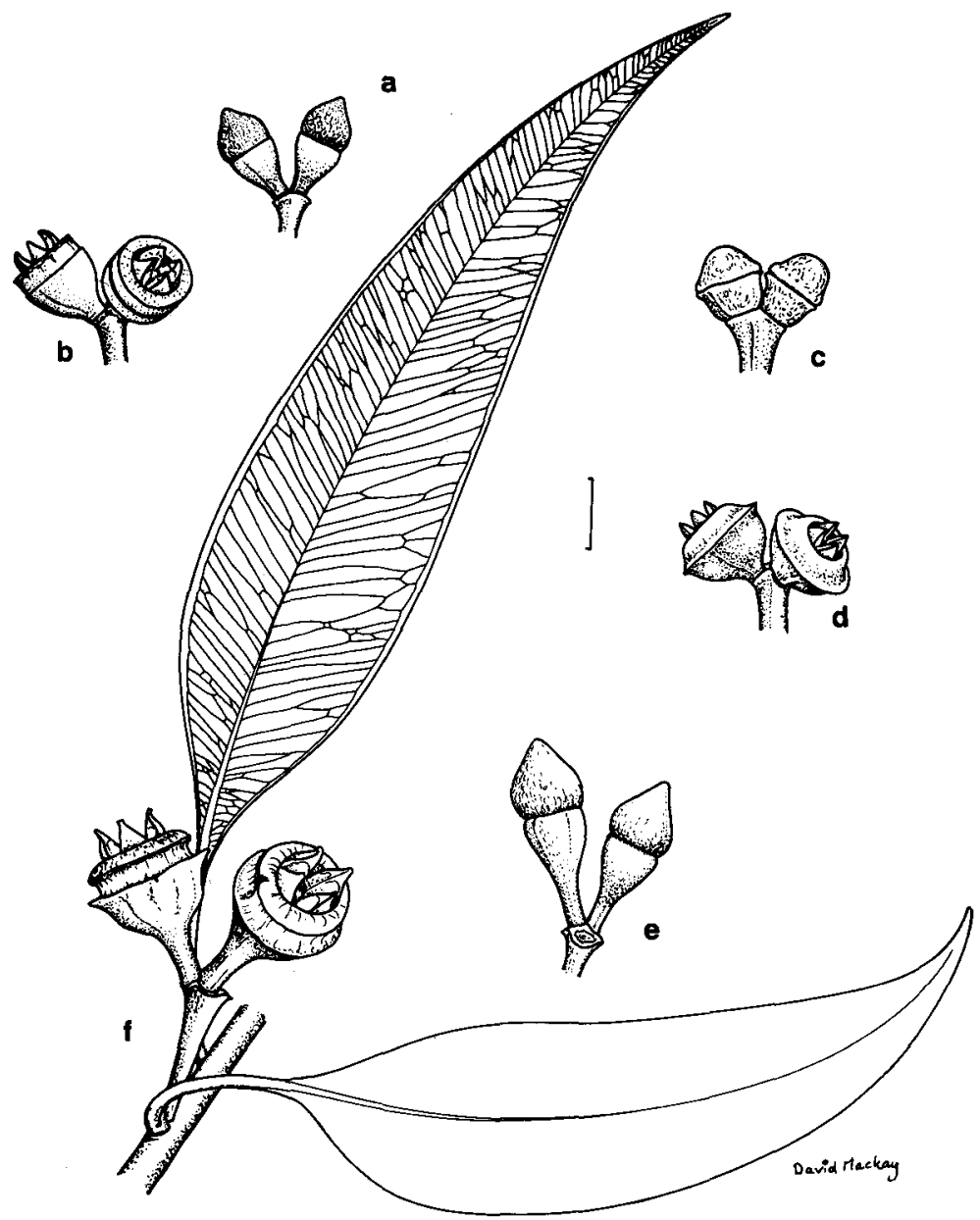

Figure 3. E. scias. a., b., buds and fruit of subsp. callimastha (from W.A.W. de Beuzeville 550). c., d., buds and fruit of subsp. apoda (from K. Hill $1283 \&$ L. Johnson). e., f., buds, fruit and leaves of subsp. scias (from J.L. Boorman, 10.1920). Scale bar $=1 \mathrm{~cm}$. 
buds clavate to fusiform, 12-23 $\mathrm{mm}$ long, 8-14 $\mathrm{mm}$ diam. Calyptra double, outer shedding early, inner hemispherical to conical, rounded or apiculate to rostrate, half to twice as long as hypanthium, often wider than hypanthium. Fruit obconical to cupshaped, 3-6-locular, 8-16 mm long, 9-20 mm diam.; calyptra scar expanded, sharply raised, 2-4 mm wide; stemonophore raised, less than $0.5 \mathrm{~mm}$ wide; disc sharply raised to flat, ultimately incurved, $1.5-3 \mathrm{~mm}$ wide; valves triangular, acute, basally deeply enclosed, apically exserted, raised at $60-90^{\circ}$ (Figure 3).

E. scias differs from E. pellita F. Muell. in the smaller, narrower, more distinctly dorsiventral adult leaves $(12-20 \mathrm{~cm}$ long, 3-5 cm wide in E. pellita) with shorter petioles (20-40 mm long in E. pellita), the smaller, narrower juvenile leaves (to $20 \mathrm{~cm}$ long in E. pellita), the more fibrous, almost stringy bark and the generally shorter pedicels (to $10 \mathrm{~mm}$ long in E. pellita). Adult leaves of E. pellita are also distinctly mucronate, with a pronounced 'drip-tip' that is lacking in E. scias.

E. pellita as now defined is restricted to north-eastern Queensland (type from Rockingham Bay, J. Dallachy, holo MEL).

Distribution: New South Wales, sporadic and disjunct, usually in coastal ranges or hilly country, east of Tenterfield, and from Cessnock to Batemans Bay (Figure 4).

The epithet is from the Greek skias, 'a shade', in reference to the broad-leaved crown.

Three subspecies may be recognised on regional differences in bud and fruit morphology.

\section{Key to subspecies}

1 Calyptra conical 5A. subsp. scias

$1 *$ Calyptra hemispherical

2 Calyptra rounded 5B. subsp. apoda

2* Calyptra apiculate 5C. subsp. callimastha

\section{A. Eucalyptus scias L. Johnson $\mathcal{E} K$ K. Hill subsp. scias}

Tree (sometimes several-stemmed) to $20 \mathrm{~m}$ high. Adult leaves green. Peduncles flattened, 6-16 $\mathrm{mm}$ long, to $7 \mathrm{~mm}$ wide apically; pedicels $2-9 \mathrm{~mm}$ long. Mature buds ovoid to fusiform, 14-23 mm long, 9-14 mm diam. Calyptra convex conical or rostrate, as long

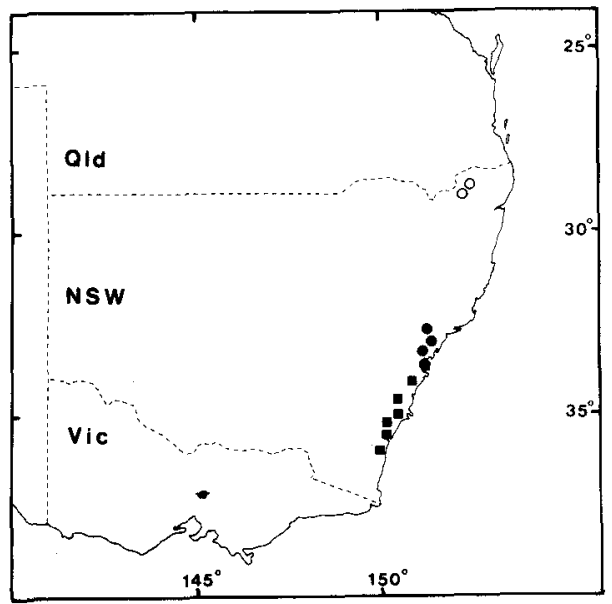

Figure 4. Distribution of E. scias subsp. scias (solid circle), subsp. apoda (open circle) and subsp. callimastha (square). 
as or longer than hypanthium. Fruit cup-shaped, 4-6-locular, 8-16 mm long, 9-20 mm diam. Calyptra scar sharply raised, 2-4 $\mathrm{mm}$ wide; disc slightly raised or flat ultimately incurved, 2-4 $\mathrm{mm}$ wide. Valves narrowly triangular, acute, basally enclosed, apically exserted, raised at $45-90^{\circ}$.

SeleCted SPECIMENS (from 25 examined): New SOUTH WAIES: North Coast: Pokolbin State Forest, 6 miles [9.6 km] SE of Broke, R. Story 7374, 8.5.1960 (NSW). Central Coast: Olney State Forest, E.F. Constable NSW 10972, 24.8.1949 (NSW); Jilliby Jilliby, W of Wyong, J.L. Boorman, 10.1920 (NSW); First Point, Kincumber, J.H. Maiden \& R.H. Cambage, 17.6.1905 (NSW); South Creek, Narrabeen, M.B. Welch, 4.1932 (NSW); North Head, R. Coveny, 26.8.1967 (NSW).

CONSERVATION STATUS: Not considered to be at risk.

5B. Eucalyptus scias L. Johnson \& K. Hill subsp. apoda L. Johnson \& K. Hill, subsp. nov.

Folia alabastraque glaucescentia; calyptra longiuscula rotunda; pedunculus brevis; fructus sessiles.

TYPE: New SOUTH WALES: Northern Tablelands: $26.0 \mathrm{~km}$ from Bruxner Highway on Poverty Point road, E of Tenterfield, K. Hill 1283, L. Johnson \& J. Williams, 10.9.1985 (holo NSW; iso BRI, CANB, K, PERTH).

Tree (sometimes several-stemmed) to at least $10 \mathrm{~m}$ high. Leaves and buds often glaucous, especially when dried. Peduncles flattened, 5-7 $\mathrm{mm}$ long, to $9 \mathrm{~mm}$ wide apically; pedicels angular, 0-2 $\mathrm{mm}$ long. Mature buds ovoid, 12-14 $\mathrm{mm}$ long, 8-10 $\mathrm{mm}$ diam. Calyptra oblong, hemispherical, rounded, slightly longer than hypanthium. Fruit sessile, obconical, 4-5-locular, 10-12 $\mathrm{mm}$ long, 10-16 mm diam. Calyptra scar vertically raised, 2-3 mm wide; disc slightly raised or flat, ultimately incurved, 2-3 mm wide. Valves narrowly triangular, acute, basally enclosed, apically strongly exserted, raised at $90^{\circ}$.

Subsp. apoda is distinguished from the other subspecies by the bluish leaves and buds, the oblong but rounded calyptra, the short peduncle and the sessile buds and fruit.

SELfCTED SPECIMENS (from 5 examined): NeW SOUTH WALES: Northern Tablelands: Drake, E.C. Andrews, 6.1904 (NSW); Type locality, K. Hill 1284, 1285 \& L. Johnson, 10.9.1985 (NSW); Parish Cavendish, County Clive, R.J. Turner, 22.10.1954 (NSW).

DistRIBUTION: New South Wales, mountain ranges of far north-western North Coast, east of Tenterfield.

ECOLOGY: Sporadic and uncommon, usually on somewhat swampy sites on granitederived soils.

The epithet is from the Greek $a-$, 'without', and pous, podos, 'a foot', in reference to the sessile buds and fruit.

CONSERVATION STATUS: 2V-. Known occurrences are in State Forest areas and possibly at some risk from forestry activities. Further study is required to establish population sizes and distributional limits.

5C. Eucalyptus scias L. Johnson \& K. Hill subsp. callimastha L. Johnson \& K. Hill, subsp. nov.

Folia adulta non vel vix glaucescentia; folia juvenilia lata; calyptra brevis mammiformisque; fructus cupuliformes, pedicellati; pedunculi longiusculi.

TYPE: NEW SOUTH WALES: South Coast: $7 \mathrm{~km}$ SSE of Batemans Bay $\left(35^{\circ} 46^{\prime} \mathrm{S}, 150^{\circ} 13^{\prime} \mathrm{E}\right)$, M.D. Crisp 6449, 4.7.1980 (holo NSW; iso CBG). 
Tree (sometimes several-stemmed) to $20 \mathrm{~m}$ high. Adult leaves green. Juvenile leaves ovate to orbicular, to $14 \mathrm{~cm}$ long, $10 \mathrm{~cm}$ wide. Peduncles flattened 8-23 mm long, to 5 $\mathrm{mm}$ wide apically; pedicels $2-5 \mathrm{~mm}$ long. Mature buds clavate to ovoid, $14-18 \mathrm{~mm}$ long, 9-12 mm diam. Calyptra hemispherical, rounded or shortly apiculate, slightly shorter than or as long as hypanthium. Fruit cup-shaped, 3-4-locular, 8-12 mm long, 9-14 mm diam. Calyptra scar sharply raised, 2-3 mm wide; disc slightly raised or flat, ultimately incurved, 2-3 mm wide. Valves narrowly triangular, acute, basally enclosed, apically exserted, raised at $45-90^{\circ}$.

Subsp. callimastha is distinguished from the other subspecies by the green adult leaves, the broad juvenile leaves, the short calyptra and the more cup-shaped, pedicellate fruit on longer peduncles.

Selected SPeCimens (from 35 examined): New SOUTH Wales: Central Coast: Helensburgh, E of rubbish tip, K. Mills, 18.6.1985 (NSW); $4 \mathrm{~km}$ SW of Meryla Pass, L. Johnson 8366, 29.10.1977 (NSW). South Coast: $1.6 \mathrm{~km} \mathrm{~S}$ of Pigeon House $\left(35^{\circ} 22^{\prime} \mathrm{S} 150^{\circ} 19^{\prime}\right.$ E), M.D. Crisp 2509, 1.5.1977 (NSW, CBG); Termeil, W.A.W. de Beuzeville 550, 10.8 .1932 (NSW); 4 miles [6.4 km] N of Batemans Bay, L. Walker 6, 11.1917 (NSW).

DistriBuTION: Coastal New South Wales, from north of Wollongong to Batemans Bay.

ECOLOGY: Scattered in wet sclerophyll forests, usually on poorer soils and sometimes extending into coastal heath scrubs. Associated with E. gummifera (Sol. ex Gaertn.) Hochr., E. maculata Hook., E. pilularis Sm., E. urceolaris Maiden \& Blakely, E. globoidea Blakely, and E. botryoides Sm.

The epithet is from the Greek kallimasthos, 'with beautiful breasts', in reference to the shape of the calyptra.

CONSERVATION STATUS: Not considered to be at risk.

6. Eucalyptus resinifera $S m$. in White, Journ. Voy. New South Wales: 231, pl. 16 (1790)

TYPE CITATION: None cited.

TYPE: NeW SOUTH WALES: Port Jackson, J. White (holo BM).

Two geographic subspecies may be defined within E. resinifera (Figure 5). This excludes populations from northern Queensland, which are considered to constitute another taxon at specific rank, to be described in due course.

\section{Key to subspecies}

1 Calyptra less than $9 \mathrm{~mm}$ long, longest peduncle less than $15 \mathrm{~mm}$ long ..6A. subsp. resinifera

$1^{*}$ Calyptra more than $9 \mathrm{~mm}$ long, longest peduncle more than $15 \mathrm{~mm}$ long 6B. subsp. hemilampra

\section{A. Eucalyptus resinifera $S m$. subsp. resinifera}

Peduncles 9-14 mm long. Pedicels 3-8 mm long. Buds 9-13 mm long; calyptra 6-9 $\mathrm{mm}$ long. Fruit 5-6 mm long, 5-7 $\mathrm{mm}$ diam.; calyptra scar and stemonophore usually less than $1 \mathrm{~mm}$ wide.

SelfCTED SPECIMENS (from 62 examined): NeW SOUTH WALes: North Coast: Booral, F.R. Rudder, 2.1894 (NSW); Parish of Fens, Tea Gardens, R. Carolin, 2.9.1983 (NSW). Central Coast: 1 mile N of Freemans Waterholes, G.M. Chippendale 460, 30.5.1968 (NSW); Lindfield, R. Baker, 8.1900 (NSW); junction of Liverpool and Cabramatta roads, J.L. Boorman, 2.1900 (NSW); $5.1 \mathrm{~km} \mathrm{~N}$ of Menai turnoff on Heathcote Road, $R$. Coveny $11163 \&$ \& J Thomas, 14.7.1982 (NSW). South Coast: $6.4 \mathrm{~km}$ NW of Huskisson, B.G. Briggs 3076, L. Johnson \& D. Blaxell, 15.12.1969 (NSW). 
Intergrading forms between the two subspecies occur in the zone from Kempsey to Taree, although this species is not abundant in that region.

Intergrading populations with $E$. notabilis Maiden are known from the area between Colo Heights and Dural. Intersectional hybrids with $E$. amplifolia Naudin are known, as are intrasectional hybrids with $E$. botryoides Sm., E. saligna $\mathrm{Sm}$. (the hybrid $=E$. botryoides Sm. var. lynei Blakely) and E. propinqua Deane \& Maiden.

CONSERVATION STATUS: Not considered to be at risk.

6B. Eucalyptus resinifera $S m$. subsp. hemilampra (F. Muell.) L. Johnson $\mathcal{E}$ K. Hill, comb. et stat. nov.

BASIONYM: Eucalyptus hemilampra F. Muell., J. Linn. Soc., Bot. 3: 85 (1859).

TYPE CITATION: 'Hab. Ad rivulos torrentesque sylvaticos secus partes fluvii Brisbane superiores. Anth. Dec., Jan.'

TYPE: Queensland: Upper Brisbane River, F. Mueller (holo MEL; iso K, NSW).

$\equiv$ E. resinifera Sm. var. grandiflora Benth., Fl. Austral. 3: 246 (1867).

Included in E. resinifera Sm. var. grandiflora Benth. by Bentham (1867); this in turn was included in E. resinifera by Maiden (Crit. Revis. Eucalyptus 3: 209 (1917)).

Peduncles 12-42 $\mathrm{mm}$ long. Pedicels 6-13 $\mathrm{mm}$ long. Buds 12-16 mm long; calyptra 10-12 mm long. Fruit 6-9 mm long, 6-8 mm diam.; calyptra scar and stemonophore usually more than $1 \mathrm{~mm}$ wide.

Distinguished from the type subspecies by the longer and more slender peduncles and pedicels, the slender, more strongly exserted valves, the relatively elongate fruit with a broad raised stemonophore and calyptra scar, and the longer calyptra.

Selected SPECimens (from 30 examined): QueENSLAND: 25 miles $[40 \mathrm{~km}$ ] E of Gympie, on Cooloola Sandhills, L.S. Smith 12131, 13.5.1964 (BRI, NSW); Mt Coolum, P.R. Sharpe 2726, 10.10.1981 (BRI, NSW); Virginia, Brisbane, S.T. Blake 4274, 24.9.1932 (BRI, NSW); Water Island, W.R. Petrie. 8.1918 (NSW). NeW South WALES: North Coast: Acacia Creek, W. Dunn, 8.1906 (NSW); Girard State Forest, on Bruxner Highway, K. Hill 813 \& L. Johnson, 9.5.1984 (NSW); Bucca

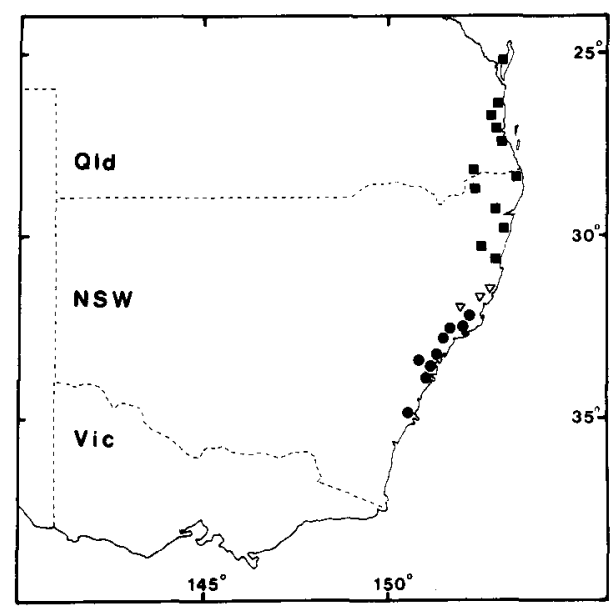

Figure 5. Distribution of E. resinifera subsp. resinifera (circle), subsp, hemilampra (square) and intergrading forms (open triangle). 
Creek, Coffs Harbour, J.L. Boorman, 6.1911 (NSW); $2.5 \mathrm{~km} \mathrm{SE}$ of Eungai Rail ( $\left.31^{\circ} 52^{\prime} \mathrm{S} 153^{\circ} 55^{\prime} \mathrm{E}\right)$, M.D. Crisp 7591 \& J.M. Taylor, 4.11.1984 (CBG, NSW).

CONSERVATION STATUS: Not considered to be at risk.

\section{Eucalyptus interstans L. Johnson \& K. Hill, sp. nov.}

E. seeanam proxima sed characteribus sequentibus differt: folia juvenilia adultaque latiora; discus fructus angustus tandem valde incurvus; calyptra oblonga vel conicoobtusa; fructus majores.

TYPE: New SOUTH WALES: Northern Tablelands: Wilsons Downfall, R.H. Cambage 2833, 4.9.1911 (holo NSW).

Tree to $20 \mathrm{~m}$. Bark smooth, patchy grey, pink, orange and brown. Seedling leaves oblong, petiolate, opposite for 3-5 nodes. Juvenile leaves disjunct, lanceolate to ovatelanceolate, obtuse or acute, $5-14 \mathrm{~cm}$ long, $1-4 \mathrm{~cm}$ wide, petioles 5-25 mm long. Adult leaves disjunct, lanceolate, acute or acuminate, often falcate, 10-20 cm long, 1.0-3.5

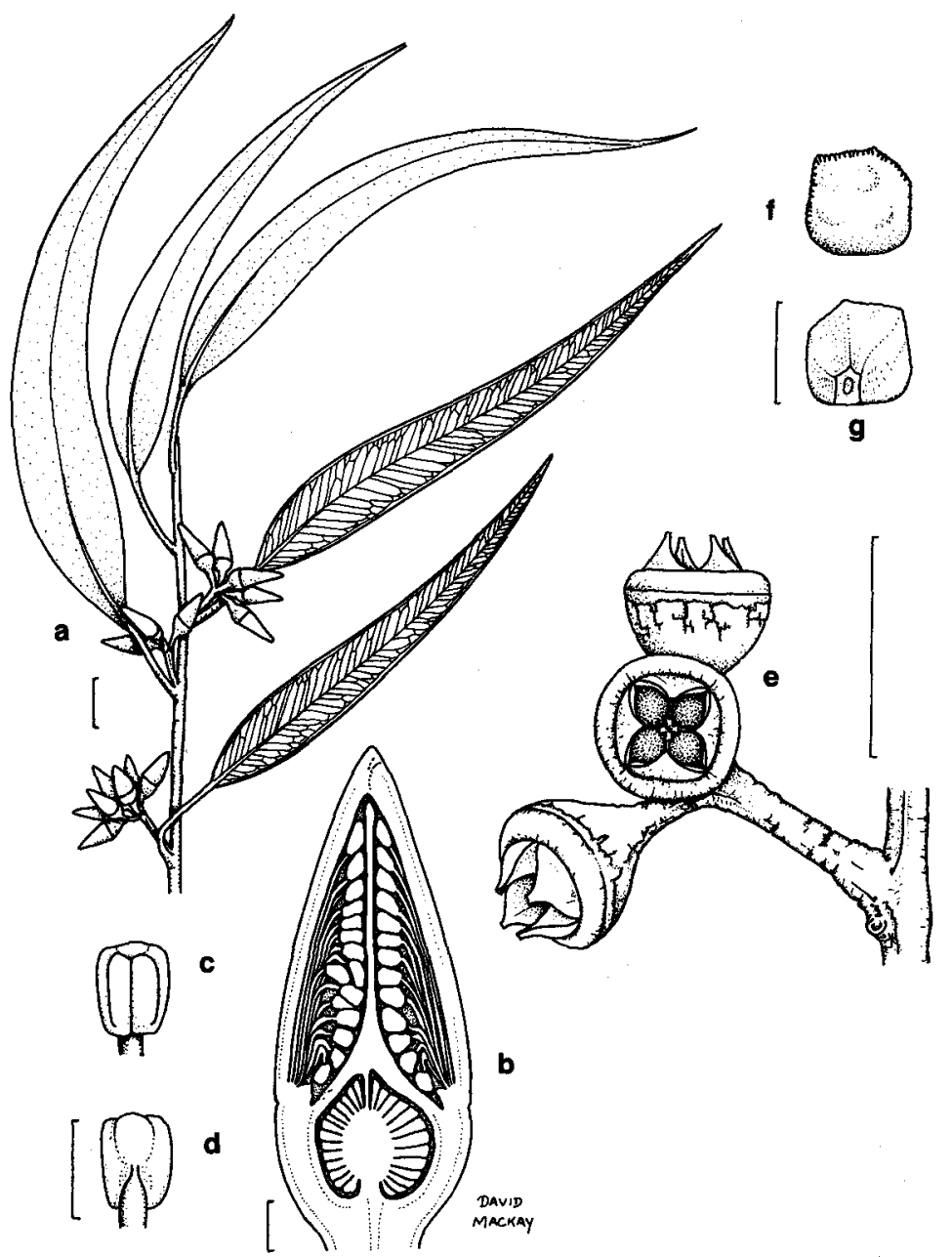

Figure 6. E. interstans. a., shoot with buds. b., median section of bud. c., d., anthers. E, fruit. f., g., seed (all from K. Hill $816 \&$ L. Johnson). Scale bar: a, b=1 cm; b,f,g $=1 \mathrm{~mm} ; \mathrm{c}, \mathrm{d}=0.5 \mathrm{~mm}$. 
$\mathrm{cm}$ wide; lateral veins well-spaced, irregular, reticulate between, at $45^{\circ}$ to midrib; intramarginal vein distinct, $1-2.5 \mathrm{~mm}$ from margin; petioles $1.0-2.0 \mathrm{~cm}$ long. Inflorescence simple, axillary; umbellasters 7-flowered; peduncles terete or slightly angular, 10-15 mm long; pedicels angular, 3-5 mm long. Mature buds 9-13 mm long, 3-5 $\mathrm{mm}$ broad. Calyptra double, outer shed early, inner $2 \frac{1 / 2}{2}-3^{1 / 2}$ times longer than hypanthium, oblong or conical, obtuse or sometimes acute, outer calyptra scar distinct. Fruit hemispherical or cup-shaped, 5-8 mm long, 5-9 mm diam., 3- or 4-locular, with vertically exserted, broadly triangular, often acuminate valves; calyptra scars forming a distinct band about $1 \mathrm{~mm}$ wide around top of hypanthium; disc narrow (to $1.5 \mathrm{~mm}$ wide), raised and ultimately strongly incurved and enclosing valve bases. Seeds dull, brown, cuboid, 0.6-0.8 mm long; chaff similar, longer and thinner (Figure 6).

$E$. interstans is distinguished from E. seeana Maiden by the lanceolate to ovatelanceolate juvenile leaves, the lanceolate adult leaves, the narrow, ultimately strongly incurved disc (disc raised and often more than $1.5 \mathrm{~mm}$ wide in E. seeana), the oblong or conical, usually obtuse calyptra, and the larger fruit (to $5 \mathrm{~mm}$ long, $7 \mathrm{~mm}$ diam. in $E$. seeana). The juvenile leaves, although broader than those of E. seeana, are still lanceolate or ovate-lanceolate, and do not approach the broad-ovate juvenile leaves of E. prava L. Johnson \& K. Hill. The buds and adult leaves are also intermediate in morphology between those of E. seeana and E. prava.

Populations intergrading with $E$. prava are known from the Stanthorpe-Wallangarra area in southern Queensland and northern N.S.W. Intergradation with E. seeana also occurs in the region east of Drake in northern N.S.W.

SELECTED SPECIMENS (from 19 examined): QueENSLAND: Hellhole Gorge, near Crows Nest, A. Bean 735, 8.2.1988 (NSW); Cherry Gully, Dalveen to Warwick, A. Bean 146, 13.3.1985 (NSW). NeW SOUTH WALES: North Coast: $3.3 \mathrm{~km}$ E of Drake $\left(28^{\circ} 56^{\prime} \mathrm{S} 152^{\circ} 24^{\prime} \mathrm{E}\right)$, K. Hill $816 \mathcal{E}$ L. Johnson, 9.5.1984 (NSW, CANB, MEL); Tooloom, R.H. Cambage 2896, 8.9.1911 (NSW); 1.1 miles [1.8 km] W of Legume, G.M. Chippendale 600 \& R.D. Johnston, 12.6.1968 (NSW).

DisTRIBUTION: South-eastern Darling Downs region of Queensland to the north-eastern Northern Tablelands and adjacent coastal ranges of New South Wales (Figure 7). The range of $E$. interstans occupies a zone lying between the ranges of $E$. seeana (a coastal species) and E. prava (a tablelands species).

ECOLOGY: E. interstans is restricted to sandy soils in drier sites, usually on ridges and slopes. The Hellhole Gorge occurrence is, however, on fairly level country with granitic outcrops above the gorge itself. E. interstans is often associated with Angophora subvelutina F. Muell., Eucalyptus tereticornis Sm., E. crebra F. Muell., E. conica Deane \& Maiden, E. moluccana Roxb., E. eugenioides Sieber ex Sprengel and E. maculata Hook.

The epithet is from the Latin inter, 'between', and stans, 'standing', referring to the position of this taxon as an intermediate between $E$. prava and E. seeana, in both geographical and morphological senses.

CONSERVATION STATUS: Not considered to be at risk.

\section{Eucalyptus prava $L$. Johnson \& K. Hill, sp. nov.}

Inter species Bancroftianarum combinatione calyptrae elongatae apice rotundatae, foliorum griseoglaucorum brevium latiusculorum saepe apice rotundatorum, innovationum alabastrorum pruinoso-glaucorum, distinguitur.

TYPE: NeW SOUTH WALES: Northern Tablelands: $2.3 \mathrm{~km}$ N. of Torrington on Silent Grove road, $R$. Coveny 5190, 7.9.1973 (Holo NSW).

= Eucalyptus tereticornis Sm. var. brevifolia Benth., Fl. Austral. 3: 242 (1867). 
Type CitATION: 'New England, in very exposed situations in the mountains, C. Stuart.' TYPe: New South WaLes: New England, C. Stuart (holo K; iso MEL, NSW).

Included in E. bancroftii by Chippendale (1988).

[E. tereticornis Sm. var. amblycorys F. Muell. ex Maiden, Crit. Revis. Eucalyptus 2: 221 (1912), 4: 15 (1917), in part, in syn., nom. invalid.]

Specimens of E. prava and E. parramattensis $C$. Hall were distributed by Mueller under the manuscript name $E$. tereticornis $\mathrm{Sm}$. var. amblycorys, which was never legitimately published or typified. Maiden also used the name 'E. brevifolia Benth.' for E. prava in the same reference, but there is no evidence that Bentham published this name other than as a variety of E. tereticornis.

Tree to $15 \mathrm{~m}$ tall, usually less than $10 \mathrm{~m}$, often of irregular habit. Bark smooth, grey with orange, white, grey-brown and dark grey patches, excorticating in large flakes. Twigs reddish, sometimes pruinose. Cotyledons reniform, $2 \mathrm{~mm}$ long, $3 \mathrm{~mm}$ wide. Juvenile leaves petiolate, disjunct, ovate, obtuse or rounded, to $13 \mathrm{~cm}$ long, $7.5 \mathrm{~cm}$ wide. Intermediate leaves smaller, ovate-lanceolate. Adult leaves ovate, ovate-lanceolate or broad-lanceolate, sometimes slightly falcate, acute, obtuse or rounded, disjunct, greygreen or glaucous, $4.5-12 \mathrm{~cm}$ long, $1.5-4.0 \mathrm{~cm}$ wide; lateral veins not regularly pinnate, reticulate between, at $45^{\circ}$ or less to midrib; intramarginal vein distinct, $1.5-3.5 \mathrm{~mm}$ from margin; petiole $1.5-2.5 \mathrm{~cm}$ long, lamina slightly decurrent. Inflorescence simple, axillary; umbellasters 7-flowered, usually pruinose or glaucous; peduncles terete, 10-20 mm long; buds and fruit sessile, or pedicels up to $6 \mathrm{~mm}$ long. Mature buds 8-13 mm long, 3-6 $\mathrm{mm}$ diam. Calyptra double, outer shed early, inner $2-3 \frac{1 / 2}{2}$ times longer than hypanthium, oblong, apically rounded or obtuse, often glaucous. Outer calyptra scar distinct, outer calyptra often remaining on near-mature buds. Fruit rounded, 7-10 mm long, 6-10 mm diam., 3- or 4-locular with vertically exserted broadly triangular valves; calyptra scars forming a distinct broad band around upper $1 / 4-1 / 2$ of hypanthium; disc narrow, raised and ultimately incurved, enclosing valve bases. Seeds glossy, dark brown, angular, cuboid, $0.5 \mathrm{~mm}$ long; chaff similar, longer and narrower.

E. prava is distinguished in the series Bancroftianae by the combination of the elongate,

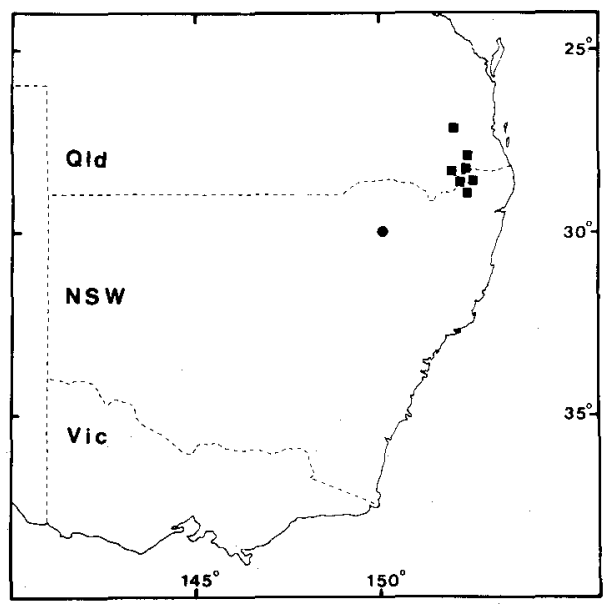

Figure 7. Distribution of E. interstans (square) and E. nandewarica (circle). 
apically rounded calyptra, the greyish glaucous foliage with short, relatively broad and often apically rounded leaves, and pruinose-glaucous shoots and buds. Specimens of this taxon have been included under $E$. bancroftii (Maiden) Maiden, from which it differs in the foliage characters (adult leaves lanceolate and frequently more than $12 \mathrm{~cm}$ long) and the glaucousness.

Populations intergrading with E. interstans are known from the StanthorpeWallangarra area in southern Queensland and northern N.S.W. Occasional hybrids between E. prava and E. dealbata A. Cunn. ex Schauer are also known in areas where the two intermingle.

SELECTED SPECIMENS (from 58 examined): QUEENSLAND: $16 \mathrm{~km}$ WSW of Stanthorpe, L. Pedley 4139 30.9.1973 (BRI, NSW); Wyberba, C.T. White 9332, 13.10.1933 (BRI, NSW). NEW SOUTH WALES: Northern Tablelands: 3 miles [4.8 km] S of Wallangarra, J.T. Waterhouse 1494, 29.8.1970 (NSW); 11 miles $[17.6 \mathrm{~km}]$ from Torrington on Silent Grove road, M.D. Crisp 7353, 29.9.1984 (CBG, NSW); $1.9 \mathrm{~km} \mathrm{E}$ of New England Highway on Sunnyside road $\left(30^{\circ} 26^{\prime} \mathrm{S} 151^{\circ} 38^{\prime} \mathrm{E}\right)$, M.I.H. Brooker 7281, 2.3.1982 (CANB, NSW); $.7 .2 \mathrm{~km} \mathrm{~N}$ of Bendemeer, K. Hill $1287 \mathcal{E}$ L. Johnson, 11.9.1985 (NSW). North Western Slopes: Howell, R. Coveny 3918, 13.12.1971 (NSW); $5 \mathrm{~km}$ E of Mt Lindesay on Barraba fire trail, K. Hill 2110, 27.8.1986 (NSW). Central Western Slopes: Paradise Rocks, Murrurundi, K. Hill 1321, 21.9.1985 (NSW).

DistRIBUTION: Darling Downs region of Queensland, restricted to the 'Granite Belt' from Stanthorpe to Wallangarra, extending into New South Wales on the western parts of the Northern Tablelands and higher elevations of the North Western Slopes on the Nandewar Range and extreme north-east of the Central Western Slopes on the Liverpool Range (Figure 8).

A specimen in NSW bears the label 'Cooma Ck, at back of gaol, L. Boorman, Dec. 1914 ', but $E$. prava has not otherwise been reported from the Southern Tablelands, and the cited locality has been searched with negative results. In the absence of corroboration, this record must be taken as an error in labelling.

ECOLOGY: Usually restricted to rocky areas and skeletal soils on siliceous granite, acid volcanic rocks or, rarely, sandstone or conglomerate. A component of dry sclerophyll woodlands, often in association with Eucalyptus andrewsii Maiden and a stringybark (such as E. stannicola L. Johnson \& K. Hill or E. laevopinea R. Baker). Other associates include E. bridgesiana R. Baker, E. malacoxylon Blakely and E. albens Benth. Populations

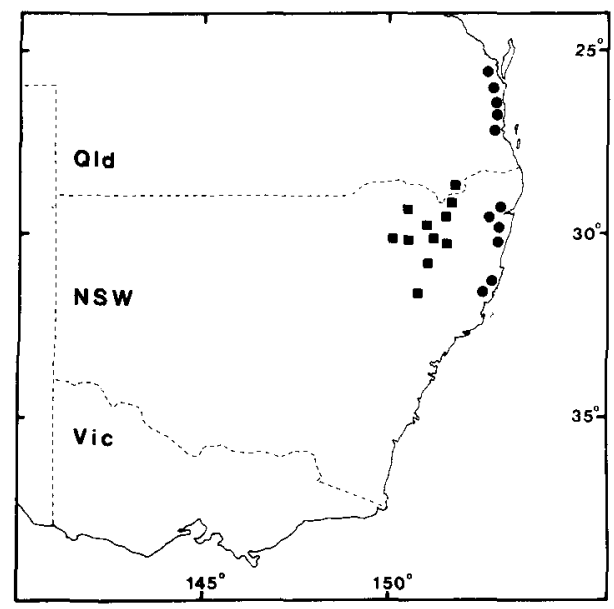

Figure 8. Distribution of E. prava (square) and E. bancroftii (circle). 
through the western part of the Northern Tablelands are relatively continuous, with small outliers in the Liverpool and Nandewar Ranges.

The epithet is from the Latin pravus, 'crooked', referring to the general 'tumbledown gum' habit of the tree.

CONSERVATION STATUS: Not considered to be at risk.

9. Eucalyptus amplifolia Naudin, Descr. Emploi Eucalyptus, 2nd Mém.: 28 (1891).

TYPE CITATION: Naudin cited no specimens, but gave the following details of occurrences: 'Je l'ai trouvé dans plusieurs endroits de l'Algérie, dans nos jardins de Provence, dans celui de M. Hanbury, à la Mortola, près de Menton; j'en ai recu des échantillons de M. Ricasoli, de Florence et nous en possédons plusieurs exemplaires de différents ages à la villa Thuret.'

TYPE: Five specimens collected by Naudin from various localities in France and Italy and now housed at $P$ may be regarded as Syntypes (n.v.).

Two geographically separated races have been identified in this taxon (Figure 9). These were separated as varieties by Blakely, although later authors did not accept this division (Pryor \& Johnson 1971). We now consider the division to be justified, and recognise the two entities as subspecies.

\section{Key to subspecies}

1 Buds and fruit distinctly pedicellate 9A. subsp. amplifolia

$1^{*}$ Buds and fruit sessile or subsessile 9B. subsp. sessiliflora

\section{A. Eucalyptus amplifolia Naudin subsp. amplifolia}

DisTRIBUTION: Widespread but patchy on the coastal plain of New South Wales from around Taree to Batemans Bay, with outliers north as far as Coffs Harbour and south to Bega. This taxon also occurs in the Megalong Valley and on the Southern Tablelands north-east of Goulburn (Figure 9).

ECOLOGY: Locally abundant or dominant on low-lying, often swampy alluvial soils on

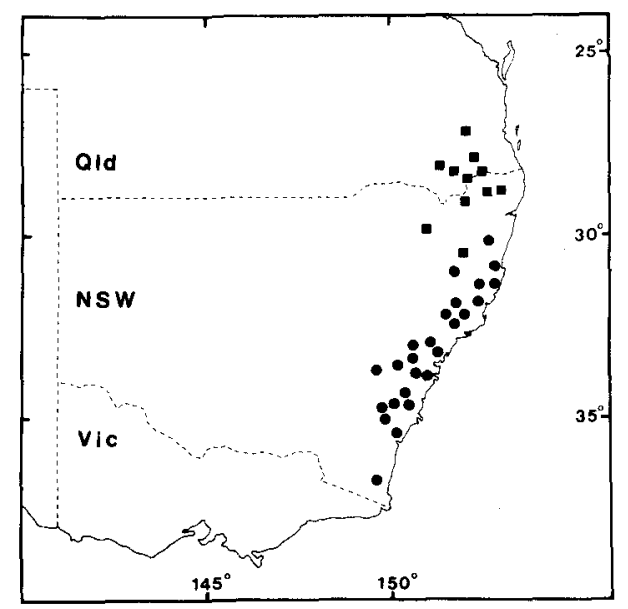

Figure 9. Distribution of E. amplifolia subsp. amplifolia (circle) and subsp. sessiliflora (square). 
creek flats and sometimes on moist hillsides. E. tereticornis $\mathrm{Sm}$. and, in tablelands areas, E. blakelyi Maiden are frequently associated with this taxon, but occurring on adjacent slightly higher and better-drained sites. Hybridism with these two species is often found in contact zones.

CONSERVATION STATUS: Not considered to be at risk.

9B. Eucalyptus amplifolia Naudin subsp. sessiliflora (Blakely) L. Johnson \& K. Hill, comb. et stat. nov.

BASIONYM: Eucalyptus amplifolia Naudin var. sessiliflora Blakely, Key Eucalypts: 131 (1934).

TyPe Citation: 'Acacia Creek, Macpherson Range (W. Dunn 47, December 1904, the type).

TYPE: holo NSW.

Distinguished from the type subspecies by the consistently sessile buds and fruit.

Selected SPECimens (from 29 examined): Queensland: Portion 1564, Parish Emu Vale, County Merivale, P. Holzworth 2, 13.9.1983 (NSW); Cottonvale turnoff, Dalveen, K. Hill 1254 \& L. Johnson, 29.8.1984 (NSW). NeW SouTH WALES: North Coast: Mallanganee, F.H.T. Ayton, 9.1910 (NSW); Woodenbong, D.J. McGillivray 306, 24.8.1957 (NSW). Northern Tablelands: 1.8 miles [2.9 km] S of Tenterfield, G.P. Smith 16, 22.1.1971 (NSW); Chandler Run to Oakey Creek, E of Armidale, A.W. Howitt, 3.1903.

DisTRIBUTION: Southern Queensland and northern New South Wales, from around Crows Nest south to east of Armidale, and east to near Casino (Figure 9).

ECOLOGY: Apparently a widely tolerant taxon, most frequently on wetter sites with gravelly soils, although sometimes on more elevated and drier sites.

CONSERVATION STATUS: Not considered to be at risk.

\section{Eucalyptus nandewarica $L$. Johnson $\&$ K. Hill, sp. nov.}

$E$. dealbatae affinis sed characteribus sequentibus differt: folia juvenilia adultaque angustiora; alabastra fructusque minus vel non glauci; umbellastrae saepe triflorae.

TYPE: New South WaLES: North Western Slopes: Waa Gorge, just upstream from twin pools, Mt Kaputar National Park (3004'S, 15006'E), K. Hill 2113, 28.8.1986 (holo NSW; iso BRI, CANB, K, PERTH).

Mallee or tree to $10 \mathrm{~m}$ high. Bark smooth, patchy white to dark grey, occasionally with a persistent fibrous stocking to 1-3 m. Seedling leaves opposite for 4-6 nodes, oblanceolate, petiolate. Juvenile leaves disjunct, lanceolate, obtuse or mucronate, to 11 $\mathrm{cm}$ long, $2.2 \mathrm{~cm}$ wide; petioles to $1.2 \mathrm{~cm}$ long. Adult leaves disjunct, similifacial, narrow- to broad-lanceolate, obtuse, acute or acuminate, $5-11 \mathrm{~cm}$ long, $0.8-2.0 \mathrm{~cm}$ wide; petioles flattened, 7-14 mm long; lateral veins closely to moderately spaced, irregular, at $30-50^{\circ}$ to midrib; reticulum open, discontinuous; intramarginal vein continuous, distinct, $0.5-1.0 \mathrm{~mm}$ from margin. Inflorescences simple, axillary; umbellasters 3-7-flowered; peduncles terete or angular, 4-8 mm long; pedicels terete or ribbed, 1-3 $\mathrm{mm}$ long. Mature buds ovoid to rhomboid, 6-8 $\mathrm{mm}$ long, 3-4 $\mathrm{mm}$ diam. Calyptra double, outer shed early, inner broadly conical, convex, obtuse or acute, 1.5-2.5 times as long as hypanthium. Stamens all fertile, filaments irregularly erect in bud, anthers elliptical, dorsifixed, versatile, dehiscing by parallel slits. Fruit cup-shaped to hemispherical, 3-4-locular, 4-5 mm long, 5-6 mm diam.; calyptra scar flat, continuous with stemonophore, the two less than $0.5 \mathrm{~mm}$ wide together; disc flat or slightly depressed 
or domed, c. $1 \mathrm{~mm}$ wide; valves broadly triangular, obtuse, strongly exserted at $45-90^{\circ}$. Seeds semi-glossy, charcoal-black, angular, cuboid or pyramidal with dentate fringes, deeply loosely reticulate, c. $1 \mathrm{~mm}$ long; hilum ventral; chaff red-brown, semi-glossy.

$E$. nandewarica differs from $E$. dealbata A. Cunn. ex Schauer in the usually lanceolate juvenile and adult leaves, the generally non-glaucous buds and fruit, and the frequently 3-flowered umbellasters. Habitat preferences also differ, with $E$. nandewarica occurring on sandstones or siliceous volcanics, whereas $E$. dealbata tends to occur on more basic volcanic rocks in similar climatic situations. E. dwyeri Maiden \& Blakely has similar juvenile leaves to those of $E$. nandewarica, although often narrower again, but differs in having distinctly larger fruit (more than $5 \mathrm{~mm}$ long, $6 \mathrm{~mm}$ diam.) with a flatter disc. It also has a more south-westerly range.

Variably glaucous populations occurring in parts of the Nandewar Range are thought to represent the result of hybridisation with $E$. dealbata.

SELECTED SPECIMENS (from 7 examined): NEW SOUTH WALES: North Western Slopes: Waa Gorge $\left(30^{\circ} 04^{\prime} \mathrm{S} 150^{\circ} 06^{\prime} \mathrm{E}\right), \mathrm{K} . L$. Wilson $6071,16.11 .1984$ (NSW); $5 \mathrm{~km} \mathrm{E}$ of Mt Lindesay on Barraba fire trail $\left(30^{\circ} 13^{\prime} \mathrm{S} 150^{\circ} 10^{\prime} \mathrm{E}\right)$, K. Hill 2108, 27.8.1986 (NSW).

Distribution: North Western Slopes of New South Wales, on and around the Nandewar Range between Bingara and Barraba, and on slopes in the Warrumbungle Range (Figure 7).

ECOLOGY: Locally abundant or dominant on skeletal sandy soils over rocky sandstone or trachyte slopes.

The epithet refers to the Nandewar Range, where this species occurs.

CONSERVATION StATUS: 3RCa. Extensive populations occur within the Mt Kaputar National Park, and have also been reported from the Warrumbungle National Park.

11. Eucalyptus camphora R. Baker, Proc. Linn. Soc. New South Wales 24: 298, pl. 12 (1899)

TYPE CitATION: 'Hab. - It was first discovered by me at Ganguddy Creek, Kelgoola, Rylestone, in 1895, and afterwards in 1897 at Narango. It has since been found at Delegate (Hayden's Bog; W. Baeuerlen). It also occurs near Tumut.'

TYPE: A specimen from the Technological Museum Herbarium, Sydney (now held at NSW) bears the following annotations in Baker's handwriting: 'Ganguddy Creek Rylestone/R.T. Baker Sept. 1895/Material on which the sp. was founded/R. T. B.' This specimen is here designated the Lectotype. The locality is correctly spelt Rylstone.

This species comprises several disjunct groups of populations (Figure 10). These are morphologically distinguishable, and are recognised here as subspecies. The related taxon previously known as E. ovata Labill. var. aquatica Blakely is here recognised as a separate species (see below).

Key to subspecies:

1 Longest petioles less than $2 \mathrm{~cm}$ long 11A. subsp. camphora

1 * Longest petioles greater than $2 \mathrm{~cm}$ long

2 Largest adult leaves less than $2.5 \mathrm{~cm}$ wide 11B subsp. relicta 2* Largest adult leaves more than $2.5 \mathrm{~cm}$ wide 11C. subsp. humeana

\section{A. Eucalyptus camphora $R$. Baker subsp. camphora}

Small tree. Bark persistent on lower trunk, hard, dark grey; smooth above. Juvenile leaves elliptical, to $11 \mathrm{~cm}$ long, $5 \mathrm{~cm}$ wide; petioles $2-2.5 \mathrm{~cm}$ long. Adult leaves broadlanceolate to ovate or elliptical, sub-glossy, 5-10 cm long, $2.5-3.5 \mathrm{~cm}$ wide; petioles 
9-17 mm long. Peduncles 4-11 mm long, 1.5-2 mm thick; pedicels 1-5 mm long. Buds turbinate, 6-7 mm long, 4-5 mm diam.; calyptra double, outer shed early, inner slightly shorter than hypanthium. Fruit obconical, mostly 3-locular, 4-5 mm long, 4-5 mm diam.; disc c. $1 \mathrm{~mm}$ wide, slightly raised then sharply depressed.

Distinguished from the other subspecies by the relatively short adult leaves with short petioles, the very short petioles on the juvenile leaves, and the small fruit.

SElECTED SPECIMENS (from 12 examined): New South Wales: Central Tablelands: Nullo Mountain, R.T. Baker, 28.8.1898 (NSW); Ganguddy Creek, 3 miles [4.8 km] E of Currant Mountain Gap, L.A.S. Johnson NSW 17708, 1.9.1951 (NSW); Blayney, Bathurst side of railway crossing, C. Debenham, 9.1969 (NSW); Megalong Creek, Megalong Valley, L.A.S. Johnson NSW 24982, 12.8.1953 (NSW).

DisTRIBUTION: Central Tablelands, from around Nullo Mountain south to the Megalong Valley. Subsequent searches of the Blayney locality have failed to locate this taxon. This may be due either to land clearing or to an erroneous annotation.

ECOLOGY: Sporadic and local, usually in small pure stands on swampy creek flats through the Central Tablelands.

CONSERVATION STATUS: Not considered to be at risk.

11B. Eucalyptus camphora R. Baker subsp. relicta $L$. Johnson $\&$ K. Hill, subsp. nov.

Inter subspecies $E$. camphorae foliis adultis parvis brevibusque petiolis longis, pedunculis longis et fructu majusculo distinguitur.

TYPE: QueEnSLAND: Girraween National Park, N. Byrnes 4094, 30.8.1982 (holo NSW; iso BRI, CANB).

Small tree or mallee. Bark persistent on lower trunk, hard, dark grey; smooth above. Juvenile leaves elliptical, to $13 \mathrm{~cm}$ long, $6 \mathrm{~cm}$ wide; petioles $2-2.5 \mathrm{~cm}$ long. Adult leaves lanceolate to broad-lanceolate, sub-glossy, $6-10 \mathrm{~cm}$ long, $1.8-2.4 \mathrm{~cm}$ wide; petioles 2-2.5 cm long. Peduncles 8-14 mm long, 1.5-2 mm thick; pedicels 3-6 mm long. Buds turbinate, 7-8 mm long, 4-5 $\mathrm{mm}$ diam.; calyptra double, outer shed early, inner

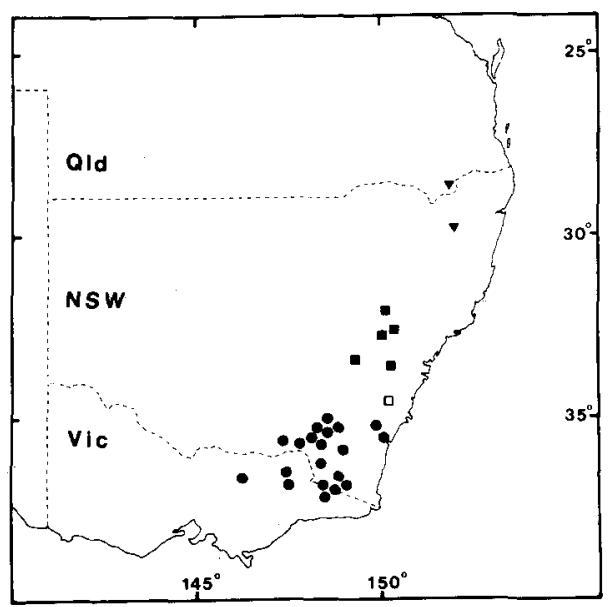

Figure 10. Distribution of E. aquatica (open square), E. camphora subsp. camphora (solid square), subsp. relicta (triangle) and subsp. humeana (circle). 
slightly shorter than hypanthium. Fruit obconical, 3-4-locular, 6-8 $\mathrm{mm}$ long, 6-8 $\mathrm{mm}$ diam.; disc c. $1 \mathrm{~mm}$ wide, slightly raised then sharply depressed.

Distinguished by the small, short adult leaves with relatively long petioles, the long peduncles and pedicels and the large fruit.

Selected SPECIMENS: QUEENSLAND: Racecourse Creek, NE of Wallangarra, L.S. Smith 754, 29.1.1940 (BRI, NSW). NEW SOUTH WALES: Northern Tablelands: 0.5 miles $[0.8 \mathrm{~km}] \mathrm{N}$ of Sara River, c. 25 miles [40 km] SE of Glen Innes, R.H. Squire, 5.5.1969 (NSW).

DISTRIBUTION: An extremely restricted taxon, known from only three small stands on swampy creek flats, one in southern Queensland and two on the Northern Tablelands of New South Wales.

The epithet is from the Latin relictus 'left behind', referring to the probability that these northern populations derive from dismemberment of a formerly more continuous distribution.

CONSERVATION STATUS: 3V. Although this taxon spans a relatively wide geographic range, populations are small and isolated. The habitat is also under threat from eutrophication and grazing activity. The N.S.W. stands are at present in somewhat isolated State Forest land, and should be secure in the short term.

11C. Eucalyptus camphora $R$. Baker subsp. humeana L. Johnson \& K. Hill, subsp. nov. Inter subspecies $E$. camphorae foliis adultis juvenilibusque magnis longisque petiolis longis, pedunculis pedicellisque longis distinguitur.

TyPE: NeW SOUTH WaLeS: Southern Tablelands: $0.5 \mathrm{~km}$ S of Lobs Hole on Ravine Road, K. Hill 739, L. Johnson \& L. Pryor, 27.4.1985 (holo NSW; iso CANB, MEL).

Small tree. Bark persistent on lower trunk, hard, dark grey; smooth above. Juvenile leaves ovate, often emarginate, to $7 \mathrm{~cm}$ long, $5 \mathrm{~cm}$ wide; petioles to $5 \mathrm{~mm}$ long. Intermediate leaves to $10 \times 10 \mathrm{~cm}$. Adult leaves broad-lanceolate to ovate or elliptical, sub-glossy, 8-15 cm long, $2.5-6 \mathrm{~cm}$ wide; petioles $1.8-3 \mathrm{~cm}$ long. Peduncles 5-15 mm long, less than $1.5 \mathrm{~mm}$ thick; pedicels 3-5 mm long. Buds turbinate, 5-7 mm long, 3-4 $\mathrm{mm}$ diam, calyptra double, outer shed early, inner slightly shorter than hypanthium. Fruit obconical, mostly 3-locular, 4-6 mm long, 4-6 mm diam.; disc c. $1 \mathrm{~mm}$ wide, slightly raised then sharply depressed.

Distinguished by the large, relatively long adult and juvenile leaves, the long petioles in adult and juvenile leaves, and the relatively long peduncles and pedicels.

SELECTED SPECIMENS (from 65 examined): NeW SOUTH WALES: Southern Tablelands: 1/4 mile [0.4 $\mathrm{km}$ ] E of Bondo Forestry settlement, M.I.H. Brooker 2970, 10.3.1971 (CANB, NSW); 2.5 miles [4.9 $\mathrm{km}$ ] from Yarrangobilly towards Rules Point, M.I.H. Brooker 2963 (CANB, NSW); Coree Flats, c. 1 mile [1.6 km] N of Mt Coree (A.C.T.), R. Eakin 9, 30.12.1969 (CANB, NSW); $7.2 \mathrm{~km} \mathrm{~N}$ of bridge over Goodradigbee River N of Brindabella, G.M. Chippendale 824, 10.2.1972 (CANB, NSW); Bago State Forest (Batlow district), W.A.W de Beuzeville 641, 15.1.1933 (CANB, NSW); Delegate, $W$. Baeuerlen 39, 1.1899 (NSW). VICTORIA: Bendoc, W. Forsyth 3, 5.1908 (NSW); 3 miles [4.8 km] N of Wulgulmerang Creek on north bank of Goodwin Creek, R. Filson 8231, 4.3.1966 (NSW, MEL); Mitta Mitta, A. Meebold 21499, 12.1936 (NSW); 42 miles [67 km] from Wodonga towards Bogong on Kiewa Valley Highway, M.I.H. Brooker 4359, 11.2.1974 (CANB, NSW).

DISTRIBUTION: A relatively abundant subspecies, occurring in small often pure stands on somewhat swampy sites on the Southern Tablelands of New South Wales, extending a short distance into north-eastern Victoria.

The epithet refers to Hamilton Hume (1797-1873), who explored and whose name is associated with the region in which the subspecies occurs.

CONSERVATION STATUS: Not considered to be at risk. 
12. Eucalyptus aquatica (Blakely) L. Johnson \& K. Hill, comb. et stat. nov.

BASIONYM: Eucalyptus ovata Labill. var. aquatica Blakely, Key Eucalypts: 140 (1934).

Type Citation: 'N.S.W. — Wingello, A. Murphy, November, 1903.'

TYPE: New SOUTh WALES: Southern Tablelands: Wingello, A. Murphy 6, 11.1903 (holo NSW).

Mallee or small tree. Bark smooth throughout. Juvenile leaves elliptical, crenate, to $5 \mathrm{~cm}$ long, $3 \mathrm{~cm}$ wide; petioles $1-5 \mathrm{~mm}$ long. Adult leaves narrow-elliptical to elliptical, sub-glossy, 5-8 cm long, $1.5-3.5 \mathrm{~cm}$ wide; petioles 9-15 mm long. Peduncles 3-7 mm long, 2-3 mm thick; pedicels 1-3 $\mathrm{mm}$ long, to $2 \mathrm{~mm}$ thick. Buds turbinate, $6-7 \mathrm{~mm}$ long, 3-4 mm diam.; calyptra double, outer shed early, inner slightly shorter than hypanthium. Fruit obconical, mostly 3-locular, 4-7 mm long, 4-7 mm diam.; disc c. 1 $\mathrm{mm}$ wide, slightly raised then sharply depressed.

Distinguished from $E$. camphora by the short adult leaves with very short petioles, the very short petioles on the juvenile leaves, the short, thick peduncles and pedicels, and the stubby fruits.

Included in E. camphora by Anderson (1956).

SEleCted SPECIMENS (from 10 examined): New South Wales: Southern Tablelands: Paddys River bridge, c. $2 \mathrm{~km} \mathrm{~N}$ of Penrose, P. Ollerenshaw 738, 28.7.1985 (CBG, MEL, NSW); K. Hill $1338 \&$ L. Johnson, 14.2.1986 (CANB, MEL, NSW, PERTH).

DistRIBUTION: Known only from a single stand on a broad swampy river flat near Penrose (Figure 10). This locality has also been cited as 'Wingello' (e.g. on type specimen), which is equally correct.

CONSERVATION STATUS: $2 \mathrm{~V}$. This taxon occurs on a poor swampy site which would not be under immediate direct threat from pastoral activity, but fire and long-term habitat modification pose a serious threat.

\section{Eucalyptus retinens L. Johnson $\mathcal{E} K$. Hill, sp. nov.}

Ab E. cypellocarpa characteribus sequentibus differt: cortex persistens subfibrosus ad modum 'box'; alabastra minora brevioraque; folia adulta minora.

TYPE: NEW SOUTH WALES: Northern Tablelands: Dyamberin Station, Connaughtmans Creek area, c. 15 miles [24 km] NW of Ebor, R.J. Turner 11, 2.8.1954 (Holo NSW 182117).

Tree to $20 \mathrm{~m}$. Bark rough, shortly fibrous-flaky, dark grey, persistent to lower branches, upper branches smooth, pale, greenish-grey or pinkish. Juvenile leaves opposite, sessile, becoming petiolate, ovate, cordate, apically tapered, obtuse, green, sub-glossy, to $12 \mathrm{~cm}$ long, $5.5 \mathrm{~cm}$ wide. Adult leaves disjunct, lanceolate, falcate, acuminate, glossy bright green, $10-17 \mathrm{~cm}$ long, $1.5-2.5 \mathrm{~cm}$ wide; petioles flattened, $1.2-2.6 \mathrm{~cm}$ long. Inflorescence simple, axillary; umbellasters 7-flowered; peduncles 2-winged, 8-17 mm long, to $5 \mathrm{~mm}$ wide at apex; pedicels angled, $0-5 \mathrm{~mm}$ long. Mature buds elongate, angular, 8-10 mm long, 4-5 mm wide. Calyptra double, outer shedding early, inner $1 / 2$ as long as hypanthium, wider than hypanthium, rounded, ultimately obtuse. Fruit cup-shaped, mainly 3-locular, faintly angular, to $10 \mathrm{~mm}$ long, $8 \mathrm{~mm}$ diam.; calyptra scar distinct, narrow, slightly raised, separated from hypanthium and disc; disc to 1.5 $\mathrm{mm}$ wide, flat or slightly raised, ultimately incurved and enclosing valve bases; valves broadly triangular, vertically raised and ultimately exserted (Figure 11).

E. retinens is distinguished from $E$. cypellocarpa $\mathrm{L}$. Johnson by the persistent, 'box'-type bark, the shorter adult leaves (often more than $17 \mathrm{~cm}$ long in E. cypellocarpa), the 
smaller buds (10-12 $\mathrm{mm}$ long in E. cypellocarpa) and the 'woodland tree' habit with a short bole and spreading canopy. The similar E. volcanica L. Johnson \& K. Hill is distinguished by the glaucous, orbicular juvenile leaves, resembling more those of $E$. goniocalyx F. Muell. ex Miq.

This taxon had previously been considered part of E. elaeophora F. Muell. as applied by Blakely (1934) to the taxon now known to be E. goniocalyx. With the correct application of E. goniocalyx and the recognition of E. cypellocarpa (Johnson 1962), E. retinens was noted as a possibly distinct taxon, and is formalized here.

$E$. alaticaulis Watson \& Ladiges recently described from Victoria is a similar parallel development within the E. cypellocarpa group, differing in the generally 'finer' buds and fruit with more slender pedicels and peduncles. The original circumscription of $E$. alaticaulis included another as yet unnamed taxon in this group occurring in coastal Victoria, from Anglesea west almost to Cape Otway. This latter taxon is coarser in all respects, but notably distinguished by the very large orbicular green juvenile leaves.

SELECTED SPECIMENS (from 12 examined): New SOUTH WALfs: Northern Tablelands: Guy Fawkes

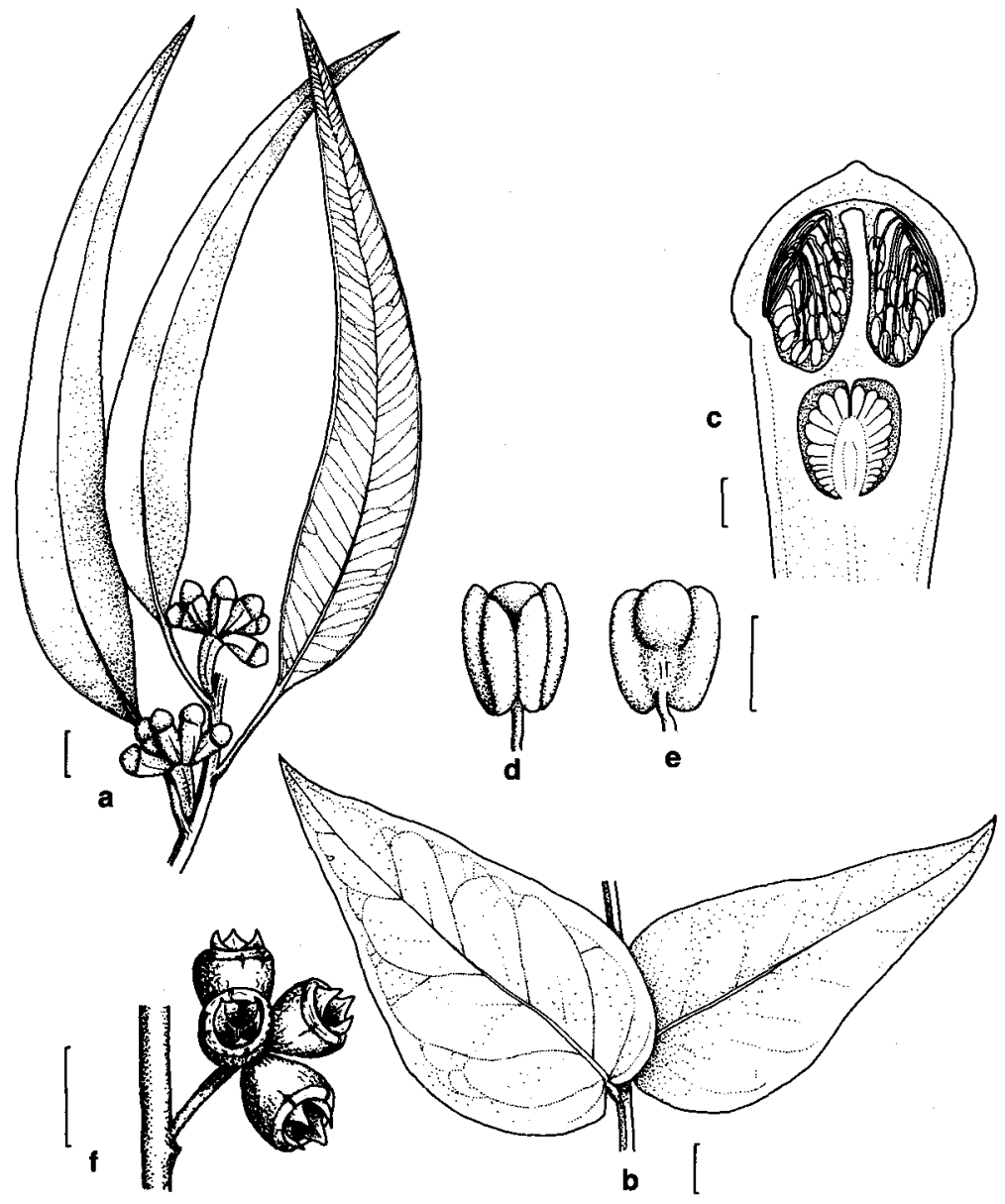

Figure 11. E. retinens. a., shoot with buds. b., juvenile leaves. c., median section of bud. d. e., anthers. f., fruit (all from R.J. Turner 11). Scale bar: $a, b, f=1 \mathrm{~cm} ; b=5 \mathrm{~mm} ; c, d=1 \mathrm{~mm}$. 
National Park, rim of Granite Gorge, D. Charley 14, 1984 (NSW); Wollomombi Gorge, E.N. McKie, 10.1.1930 (NSW); Wollomombi Falls, M.I.H. Brooker 6069, 23.1.1979 (CANB, NSW); 1 mile [1.6 km] NW of Hillgrove, L.A.S. Johnson NSW 182115, 25.2.1958 (NSW); side of Tia River, below falls, W. Forsyth, 10.1900 (NSW); Kangaroo Flat road, 7 miles [11.2 km] NE of Yarrowitch, J.C. Cousins, 21.2.1956 (NSW).

DISTRIBUTION: NEW SOUTH WALES: Eastern parts of the Northern Tablelands, in scattered stands at the heads of gorges of the Macleay and southern Clarence River systems (Figure 12).

ECOLOGY: Distinctly localized in occurrence, on shallow soils over Palaeozoic sediments or rarely granites, at immediate edges of steep gorges or upper parts of steep ridges, in association with E. melliodora A. Cunn. ex Schauer, E. viminalis Labill. and E. laevopinea R. Baker.

The epithet is from the Latin retinens, 'retaining', referring to the persistent bark.

CONSERVATION STATUS: Not considered to be at risk.

\section{Eucalyptus volcanica L. Johnson $\mathcal{E} K$. Hill, sp. nov.}

Inter species $E$. cypellocarpae affines combinatione characterum sequentium distinguitur: cortex trunci persistens, folia juvenilia orbicularia glaucaque, calyptra acuta conica basi constricta, fructus pedicellatus valvis fere inclusis.

TYPE: NeW SOUTH WALES: Northern Tablelands: $5 \mathrm{~km}$ E. of Mt Lindesay on Barraba fire trail, K. Hill 2111, 27.8.1986 (holo NSW; iso BRI, CANB, CBG, PERTH).

Tree to $25 \mathrm{~m}$ tall. Bark variably persistent, ranging from lower trunk to full trunk and large to middle branches, grey, fibrous-flaky; shedding above. Juvenile leaves opposite, orbicular to ovate, sessile, rounded, sometimes acute, glaucous or pruinose on both sides, crenulate, to $5.5 \mathrm{~cm}$ long, $4.5 \mathrm{~cm}$ wide. Adult leaves disjunct, lanceolate, falcate, glossy bright green, $10-18 \mathrm{~cm}$ long, $1.3-3.0 \mathrm{~cm}$ wide, petioles $1.5-3.3 \mathrm{~cm}$ long. Inflorescence simple, axillary; umbellasters 7-flowered; peduncles $8-14 \mathrm{~mm}$ long, flattened apically; pedicels $2-6 \mathrm{~mm}$ long. Buds ovoid, constricted at suture between calyptra and hypanthium, to c. $7 \mathrm{~mm}$ long, $4 \mathrm{~mm}$ diam. Calyptra double, outer shed

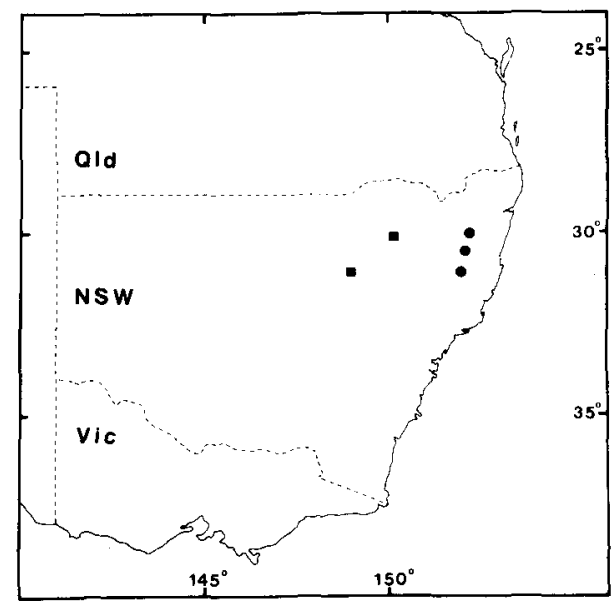

Figure 12. Distribution of E. retinens (circle) and E. volcanica (square). 
early, inner conical, inflated, \pm rostrate, about half as long as hypanthium. Fruit cupshaped, usually 3-locular, 8-10 $\mathrm{mm}$ long, 7-9 mm diam.; calyptra scar flat; disc initially flat, then sharply descending; valves level with rim to slightly exserted.

Distinguished by the combination of persistent bark on the trunk, orbicular glaucous juvenile leaves, acute conical calyptra with a basal constriction, and pedicellate fruit with substantially enclosed valves.

Selected SPECIMENS (from 10 examined): NeW SOUTH WALES: Northern Tablelands: Rangers Lookout, Plains of Heaven track, L.A.S. Johnson 7842, 1.9.1974 (NSW); $1 \mathrm{~km} \mathrm{~W}$ of Coryah Gap archway on Mt Kaputar-Narrabri road, K.L. Wilson 2472 \& J.T. Waterhouse, 19.8.1979 (NSW); Mt Kaputar, M.I.H. Brooker 4758, 15.4.1975 (CANB, NSW); foot of Mt Lindesay, R.H. Cambage 2413, 5.11.1909 (NSW); Mt Kaputar plateau, B.G. Briggs 4304, 5.6.1971 (NSW). North Western Slopes: Siding Springs observatory hill, M.I.H. Brooker 5205, 1.7.1976 (CANB, NSW); top of Mt Bulaway, W. Forsyth, 10.1899 (NSW).

DISTRIBUTION: Sporadic stands in higher parts of the Nandewar and Warrumbungle Ranges (Figure 12).

ECOLOGY: Locally frequent, on a range of sites on relatively shallow soils on elevated country on mainly trachytic volcanics.

The epithet is from the Latin volcanicus, referring to the trachyte and similar volcanic substrates on which it grows.

CONSERVATION STATUS: Not considered to be at risk.

\section{Eucalyptus nobilis $L$. Johnson \& $K$. Hill, sp. nov.}

$\mathrm{Ab}$ E. viminali characteribus sequentibus differt: cortice ex toto laevi; umbellastrae 7-florae; folia juvenilia majora latiora nitidiora; folia adulta majora.

TYPE: New South WALES: Northern Tablelands: $17 \mathrm{~km}$ NW of Nowendoc on the main divide, L. Johnson 9021, 23.4.1984 (holo NSW; iso CANB, BRI).

Tree to $70 \mathrm{~m}$; bole long, straight. Bark smooth, white, pale grey or pale grey-green, excorticating in long ribbons. Juvenile leaves opposite, sessile, glossy green, eventually becoming petiolate, lanceolate to broad-lanceolate, acute, to $15 \mathrm{~cm}$ long, $5 \mathrm{~cm}$ wide.

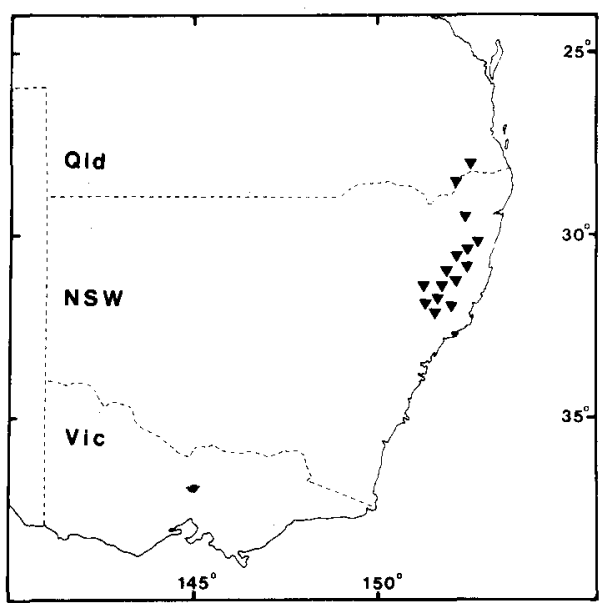

Figure 13. Distribution of E. nobilis. 
Adult leaves disjunct, lanceolate, acuminate, often falcate, 8-20 cm long, $1.0-3.0 \mathrm{~cm}$ wide; petioles 1-3 cm long. Inflorescence simple, axillary; umbellasters 7-flowered; peduncles 2-angled, 5-12 mm long; pedicels 0-3 mm long. Mature buds ovoid, 7-9 mm long, c. $4 \mathrm{~mm}$ diam. Calyptra double; outer shedding early; inner as long as hypanthium, convex, usually acute or rostrate, sometimes obtuse. Fruit cup-shaped, 3rarely 4-locular, 4-6 mm long, 5-7 mm diam.; calyptra scar distinct, narrow, continuous with hypanthium; disc 1-2 mm wide, domed; valves vertically exserted, ultimately incurved, broadly triangular, obtuse.

E. nobilis is distinguished from E. viminalis Labill. by the consistently tall, straight habit with a long bole, the smooth bark virtually throughout, the 7 -flowered umbellasters and the larger juvenile leaves (usually less than $12 \mathrm{~cm}$ long in E. viminalis). The juvenile leaves are also relatively broader and glossier than those of $E$. viminalis (which has linear to narrow-lanceolate juvenile leaves).

E. nobilis had been recognised as distinct from typical E. viminalis and included in $E$. huberiana Naudin by Blakely (1934), his concept of which also included $E$. viminalis Labill. subsp. cygnetensis Boomsma (now separated), as well as an introgessive hybrid series between E. viminalis and E. nova-anglica Deane \& Maiden which develops 7 -flowered umbellasters. No type is known for E. huberiana, and the description suggests that it may be a hybrid of E. viminalis.

Intergrades between $E$. viminalis and $E$. nobilis occur in the north-eastern parts of the Northern Tablelands. Hybrids between E. nobilis and E. nitens (Deane \& Maiden) Maiden are also known but are not abundant.

SELECTED SPECIMENS (from 51 examined): QuEENSLAND: E of Tannymorel on the main range, S.T. Blake 19225, 16.9.1955 (NSW, BRI); Cunninghams Gap, L. Johnson NSW 222311, 3.6.1961 (NSW). New South WALES: Northern Tablelands: Mt Bajimba, A. Floyd 839, 19.1.1978 (NSW). 0.9 km from Ebor-Grafton road on North Dorrigo road, K. Hill 2734, L. Johnson \& P. Weston, 18.10.1987 (NSW); Styx River State Forest, F.M. Bailey, 3.1 .1935 (NSW); $3 \mathrm{~km}$ along Fenwick Road from Oxley Highway, P. Hind 4697, 7.12.1986 (NSW); Doyles River State Forest, near Wauchope, $M$. Clayton 19, 29.4.1987 (NSW, CBG); Cairds Gap, Liverpool Range, L.A.S. Johnson \& E.F. Constable NSW 32038, 31.10.1954 (NSW); Tomalla Tableland, H.L. White 3, 7.1918 (NSW).

DISTRIBUTION: Ranges of the south-eastern Darling Downs of Queensland, extending south along the ranges of eastern Northern Tablelands of New South Wales, and west along the Liverpool Range (Figure 13).

ECOLOGY: This species occurs in tall forests on deep, fertile soils at high altitudes in high rainfall areas, often in association with $E$. obliqua L'Hérit. and sometimes $E$. fastigata Deane \& Maiden, usually in the vicinity of E. pauciflora Sieber ex Sprengel woodland. At slightly lower altitudes, E. nobilis adjoins and sometimes occurs within tall forests of E. saligna $\mathrm{Sm}$. with associated species such as E. microcorys $\mathrm{F}$. Muell.

The epithet is from the Latin nobilis, 'noble' or 'excellent', referring to the tall, straight habit.

CONSERvation Status: Not considered to be at risk.

16. Eucalyptus elliptica (Blakely $\mathcal{E}$ McKie) L. Johnson $\mathcal{E}$ K. Hill, comb. et stat. nov.

BASIONYM: Eucalyptus mannifera Mudie var. elliptica Blakely \& McKie in Blakely, Key Eucalypts: 148 (1934).

TYPe citation: '. . depicted on Plate 111 from Mt Lindsay Station, Nandewar Mtns, 3200 feet, the type'.

TYPE: New South Wales: Mt Lindsay Station, Nandewar Mtns, $3200 \mathrm{ft}$ [970 m], R.H. Cambage 2348, 4.11.1909 (Holo NSW). 
$\equiv$ E. mannifera Mudie subsp. elliptica (Blakely \& McKie) L. Johnson, Contrib. New South Wales Natl Herb. 3: 108 (1962).

Juvenile leaves opposite, ovate to orbicular. Intermediate leaves disjunct, broadlanceolate to ovate, falcate. Adult leaves disjunct, broad-lanceolate. Buds rounded, with long pedicels $(2-4 \mathrm{~mm})$.

Detailed studies by the authors and others (Chappill 1988) suggest that the members of the 'mannifera group' are not as closely related to each other as previously thought (although not necessarily a paraphyletic group). E. elliptica and E. praecox Maiden are consequently regarded as distinct species. The former thus requires a new combination at specific rank. The appropriate nomenclatural combination for the latter already exists.

SELECTED SPECIMENS (from 28 examined): NEW SOUTH WALES: Northern Tablelands: Mt Kaputar, M.I.H. Brooker 4757, 15.4.1975 (CANB, NSW); $0.7 \mathrm{~km} \mathrm{~N}$ of Oakey River hydro track on Armidale-Kempsey road, K. Hill 1303 \& L. Johnson, 12.9 .1985 (NSW); c. 9 miles [14 km] E of Armidale, M.I.H. Brooker 3919, 29.2.1973 (CANB, NSW); 3 miles [4.8 km] N of Bendemeer on New England Highway, J.B. Williams 710, 5.1959 (NSW); $4.5 \mathrm{~km}$ SSE of Bendemeer on New England Highway, G.M. Chippendale 1244 \& M.J. Brennan, 11.4.1975 (CANB, NSW); 16 miles [26 $\mathrm{km}$ ] from Walcha on Yarrowitch road, F.M. Bailey 8, 3.1.1935 (NSW); Hanging Rock, J.B. Williams NE043515A, 6.11.1983 (NSW, NE); J.H. Maiden \& J.L. Boorman, 6.1906 (NSW); NW slopes of Tomalla Tableland, L. Johnson, 30.11.1954 (NSW); 34 miles [54 km] E of Murrurundi, R. Story 7516, 13.10.1960 (CANB, NSW).

DisTRIBUTION: Scattered and locally frequent through the Northern Tablelands, from east of Armidale south to east of Murrurundi, with an outlying population near $\mathrm{Mt}$ Kaputar (Figure 14).

CONSERVATION STATUS: Not considered to be at risk.

17. Eucalyptus triplex $L$. Johnson $\mathcal{E} K$. Hill, sp. nov.

$\mathrm{Ab}$ E. cinerea characteribus sequentibus differt: fructus parvi, sessiles, campanulati; folia adulta disjuncta, parva, lanceolata.

Type: Australian Capital Territory: SE Brindabella Range, on unnamed peak

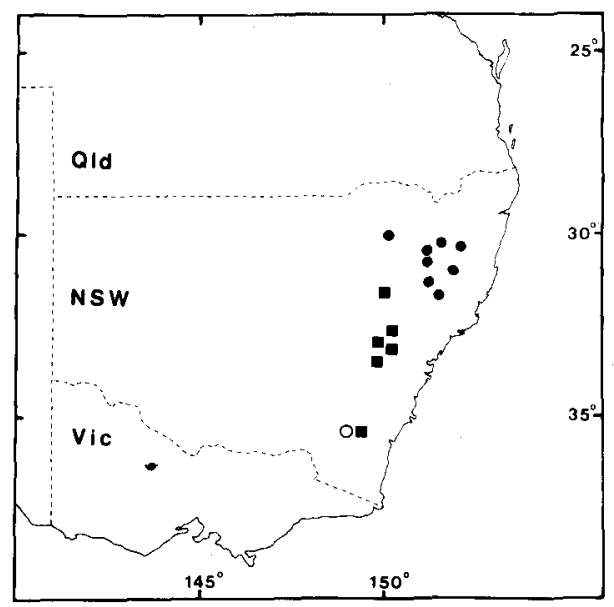

Figure 14. Distribution of E. elliptica (solid circle), E. praecox (square) and E. triplex (open circle). 
$\left(35^{\circ} 32^{\prime} \mathrm{S} 148^{\circ} 58^{\prime} \mathrm{E}\right), \mathrm{K}$. Hill $1344 \mathcal{E}$ L. Johnson, 15.2.1986 (holo NSW, iso CANB).

Tree or mallee to $6 \mathrm{~m}$ tall. Bark fibrous, dark brown, branches smooth from c. $7 \mathrm{~cm}$ diam. Juvenile leaves opposite for many nodes, sessile, orbicular, often broader than long, emarginate, crenulate, strongly glaucous, to $4 \mathrm{~cm}$ long, $5 \mathrm{~cm}$ wide. Adult leaves disjunct, lanceolate to elliptical, acute, strongly glaucous, $5-10 \mathrm{~cm}$ long, $1.5-3.2 \mathrm{~cm}$ wide; petioles 5-14 mm long; lateral veins regular, widely spaced, at $30-50^{\circ}$ to midrib; intramarginal vein distinct, \pm looped, 1-3 mm from margin. Inflorescences simple, axillary; umbellasters 3-flowered; peduncles terete, $3-8 \mathrm{~mm}$ long. Buds sessile, glaucous, ovoid to turbinate, 6-7 $\mathrm{mm}$ long, 3-4 $\mathrm{mm}$ diam. Calyptra double; outer calyptra shedding early; inner calyptra c. $1 / 2$ as long as hypanthium, hemispherical to shortly conical, obtuse. Filaments irregularly flexed, all fertile; anthers oblong, dehiscing by short, broad, parallel slits. Fruit sessile, glaucous, campanulate, 3-4-locular, 5-7 mm long, 5-7 mm diam.; calyptra and stemonophore scars raised at c. $45^{\circ}$, c. $0.5 \mathrm{~mm}$ wide; disc flat, curving down towards centre, c. $1 \mathrm{~mm}$ wide; valves broadly triangular, enclosed. Seeds ovoid, dull charcoal grey, shallowly reticulate, hilum ventral; chaff red-brown.

Distinguished from $E$. cinerea F. Muell. by the small, sessile, campanulate fruits (to 8 $\mathrm{mm}$ long, $9 \mathrm{~mm}$ diam. in E. cinerea) and the small, disjunct, lanceolate adult leaves (to $12 \mathrm{~cm}$ long, but usually not produced at all in E. cinerea).

Selected SPECIMENS (from 9 examined): Australian CAPITAL TerRITORY: West face of unnamed mountain, Namadji Natl Park, R. Gilmour 2216, D.J. Boland \& C.M. Black, 8.2.1985 (CANB, NSW); $3 \mathrm{~km}$ NW of Booroomba Rocks, I.R. Telford 10135 \& P. Beesley, 11.12.1985 (NSW, CBG).

DISTRIBUTION: known from a single site in the ranges to the east of the Bimberi Range in the southern A.C.T. (Figure 14).

ECOLOGY: Locally frequent in cracks in a broad microgranite outcrop, with numerous scleromorphic shrub species. E. dalrympleana Maiden subsp. dalrympleana and $E$. pauciflora Sieber ex Sprengel occur on adjacent deeper soils.

The epithet is from the Latin triplex, 'triple', in reference to the 3-flowered umbellasters.

CONSERVATION STATUS: 2VCt. The entire population is in a remote area in Namadji National Park, and secure from all but catastrophic fire.

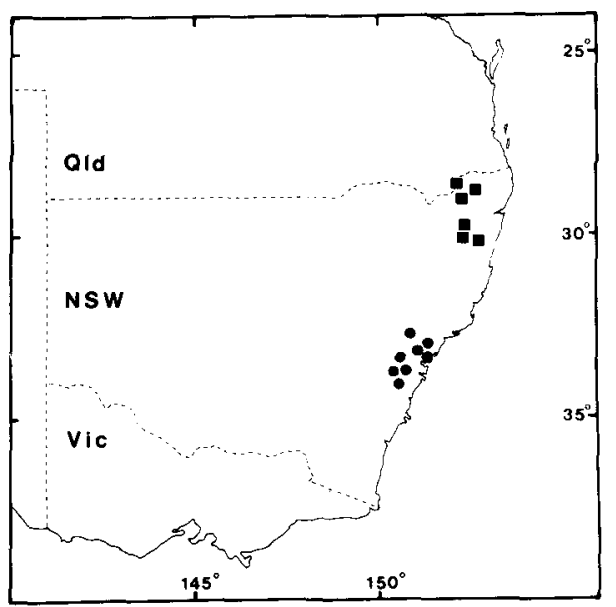

Figure 15. Distribution of E. benthamii (circle) and E. dorrigoensis (square). 
18. Eucalyptus dorrigoensis (Blakely) L. Johnson $\mathcal{E}$ K. Hill, comb. et stat. nov.

BASIONYM: Eucalyptus benthamii Maiden \& Cambage var. dorrigoensis Blakely, Key Eucalypts: 162 (1934).

TYPE CITATION: 'N.S.W. - Wild Cattle Creek and Megan, Dorrigo District, at an elevation of 2-3000 feet. (D.C. Kennedy, 3/1920 and W.A.W. de Beuzeville specimens constitute the type.)

TyPe: New SouTh WaLES: Wild Cattle Creek, Dorrigo, W.A.W. de Beuzeville NSW 118429, 9.1931 (lecto: NSW, here designated). This sheet was mounted and labelled 'Type' by Blakely, and the front cover annotated with his Key number, a procedure he followed with specimens that he selected as the single Type for the species.

Juvenile leaves elliptical. Umbellasters 7-11-flowered. Buds obtuse, not glaucous.

E. dorrigoensis has in the past been included in E. benthamii Maiden \& Cambage, which it superficially resembles. The two differ markedly in structure of the outer calyptra, however, that of $E$. dorrigoensis shedding normally well before anthesis with a welldefined abscission layer. The abscission layer appears to be suppressed in $E$. benthamii, with outer calyptra growth stopping in young buds, and the still expanding inner calyptra bursting through the top as the buds develop. This leaves several irregular scarious remnants attached, which usually dry and fall before anthesis (as observed by Brooker \& Kleinig 1983).

SELECTED SPECIMENS (from 31 examined): NEW SOUTH WALES: Northern Tablelands: Boonoo Boonoo Falls, L.G. Rutley, 12.7.1956 (NSW); 20 miles $[32 \mathrm{~km}] \mathrm{W}$ of Drake, C.E. Harbison, 26.1.1954 (NSW); Black Snake Creek, Bruxner Highway, K. Hill 812 \& L. Johnson, 9.5.1984' (NSW); N boundary of London Bridge State Forest $\left(29^{\circ} 50^{\prime} \mathrm{S} 152^{\circ} 10^{\prime} \mathrm{E}\right)$, R.H. Squire, 17.11.1969 (NSW); Paddys Land State Forest, R.J. Turner, 13.5.1955 (NSW); Megan, K. Hill 2729, L. Johnson \& P. Weston, 18.10.1987 (NSW); Moonpar turnoff, NW of Dorrigo, M.I.H. Brooker 6078, 23.1.1979 (CANB, NSW).

DISTRIBUTION: Scattered and locally abundant through the north-eastern Northern Tablelands of New South Wales. This species is dominant in country north-west of Dorrigo, but by no means restricted to that area (Figure 15).

ECOLOGY: Usually on relatively fertile but well-drained soils of a variety of types and origins.

CONSERVATION STATUS: Not considered to be at risk.

\section{Eucalyptus coolabah Blakely $\mathcal{E}$ Jacobs in Blakely, Key Eucalypts: 245 (1934).}

TYPE CITATION: Blakely cites several figures from Maiden (Crit. Revis. Eucalyptus 2: pl. 52), and a number of localities in N.S.W., Qld, S.A., N.T. and W.A.

TYPE: NEW South WALES: Bogan R., near Coolabah, J.H. Maiden \& J.L. Boorman NSW 33887, 26.3.1904 (lecto NSW, here designated). Illustrated by Maiden (Crit. Revis. Eucalyptus 2: pl. 52, fig. 18c). This specimen best illustrates the diagnostic features of the species, and was cited by Blake (1953) as the type, although he did not formally designate it as lectotype.

The 'coolibahs' are a complex group forming a geographic replacement mosaic over much of inland Australia. Some 10 or 11 entities may be distinguished, and will be treated in detail in a forthcoming account of the group. Blakely (1934) recognised part of the complexity, with his recognition of 3 species and 3 varieties. Blake (1953), however, took a broader view, reducing these to two species only. We now regard $E$. coolabah as a distinct species, and accept one of Blakely's varieties, var. arida, as a subspecies (the other, var. rhodoclada, we would regard as a distinct species, and will discuss elsewhere). We also distinguish a third subspecies in E. coolabah, as below. 
E. coolabah is the south-eastern and eastern 'coolibah' of QId, N.S.W., S.A. and N.T., extending through much of the drier country south, east and north-east of Alice Springs. It is the only member of the group in S.A., N.S.W. and the major part of Qld, extending north to the divide between the inland and Gulf river systems.

Bark persistent on trunk and lower branches, 'box'; middle and outer branches smooth, white. Calyptra hemispherical to conical. Fruit hemispherical; disc narrow, depressed; valves stongly exserted, spreading; pedicel 2-4 $\mathrm{mm}$ long, slender.

Three geographically separated subspecies may be distinguished on the basis of adult leaf morphology. There are extensive zones of intergradation where the ranges of the subspecies adjoin (Figure 16).

\section{Key to subspecies}

1 Buds, fruit and twigs glaucous 19A. subsp. coolabah

$1 *$ Buds, fruit and twigs not glaucous

2 Calyptra conical, acute 19B. subsp. excerata

2* Calyptra rounded, obtuse 9C. subsp. arida

\section{A. Eucalyptus coolabah Blakely \& Jacobs subsp. coolabah}

Adult leaves chartaceous, glaucous. Calyptra double, outer shed early, inner conical, acute or obtuse, about as long as hypanthium. Twigs, buds and fruit glaucous.

This subspecies occupies the centre of the range of the species, from around Menindee east to the Macquarie Marshes, north through the grey clay soil plains country of the Warrego, Bulloo and Barcoo river systems to Winton. Usually on flat sites on heavy, grey, cracking clay soils.

Intergradation is extensive with both subsp. excerata and subsp. arida. Intergrading populations are frequently highly variable, showing a full range of variation between the two taxa within single stands. Hybrids are also known with E. largiflorens F. Muell., E. intertexta R. Baker and E. ochrophloia F. Muell.

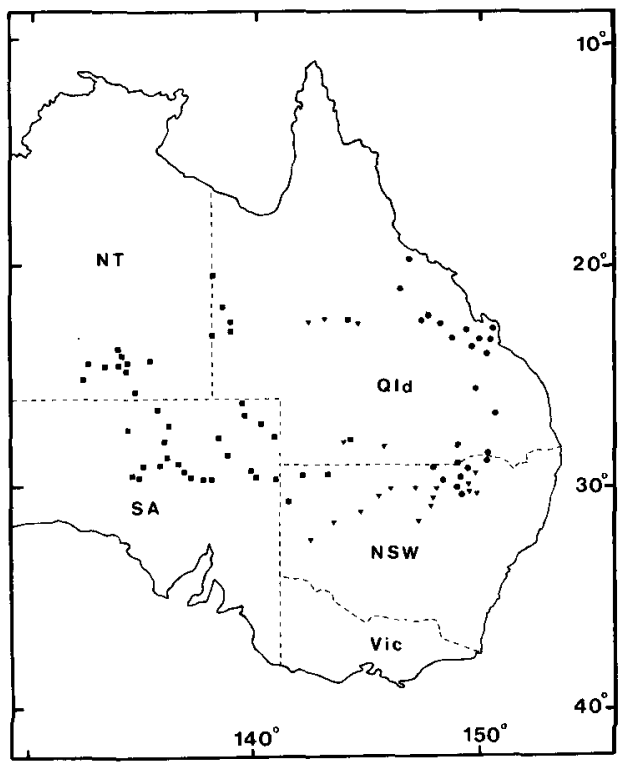

Figure 16. Distribution of E. coolabah subsp. coolabah (triangle), subsp. excerata (circle) and subsp. arida (square). 
SELECTED SPECIMENS (from 33 examined): QueENSLAND: Creek near Winton, S.W. Jackson 6A, 8.1918 (NSW); Diamantina River, F.M. Bailey, 6.1892 (NSW); Muttaburra, C.T. White, 4.1919 (NSW, BRI); Mackenzie River, N of Duaringa, A.N. Rodd 4405, 15.4.1985 (NSW, BRI); Gilruth Plains, Cunnamulla, R. Roe G19, 2.1941 (CANB, NSW). NEW SOUTH WALES: North Western Plains: Bourke, J.L. Boorman NSW 10049, 6.1901 (NSW); Bourke district, O.C. McDougal NSW 10048, 1897 (NSW); Darling River near 'East Toorale', K. Wells \& J. Curtis 60, 25.3.1973 (CANB, NSW); 130.7 $\mathrm{km}$ E of Barwon River Bridge at Collarenebri, B. Wiecek 125, 22.8.1987 (NSW, BRI, CANB); Namoi River, Narrabri, G. Burrow, 1.1930 (NSW); Wee Waa, R.T. Baker, 7.1911 (NSW); Boolcarrol, J. Hay, 12.1911 (NSW); Macquarie Marshes 80 miles [128 km] N of Warren, E.F. Constable NSW 20392, 2.5.1952 (NSW); Sandy Camp station, 10 miles [16 km] W of Quambone, G.M. Chippendale \& E.F. Constable NSW 19216, 22.5.1951 (NSW). Far North Western Plains: 'Nangara', Acres Billabong, $17 \mathrm{~km}$ E of Tilpa, D. Ferguson, 22.12.1974 (NSW); $10 \mathrm{~km}$ E of Darling River bridge at Wilcannia, K. Hill 825 \& L. Johnson, 6.7.1984 (AD, CANB, NSW, PERTH). Far South Western Plains: Kinchega National Park, G. Ryan \& J. Everly [McBarron No. 16750], 2-5.6.1969 (NSW). South Australia: Coopers Creek, Lake Perigundi $\left(27^{\circ} 47^{\prime} \mathrm{S} 139^{\circ} 34^{\prime} \mathrm{E}\right)$, B.C. Crisp 550, 3.6.1979 (NSW, AD, CBG).

CONSERVATION STATUS: Not considered to be at risk.

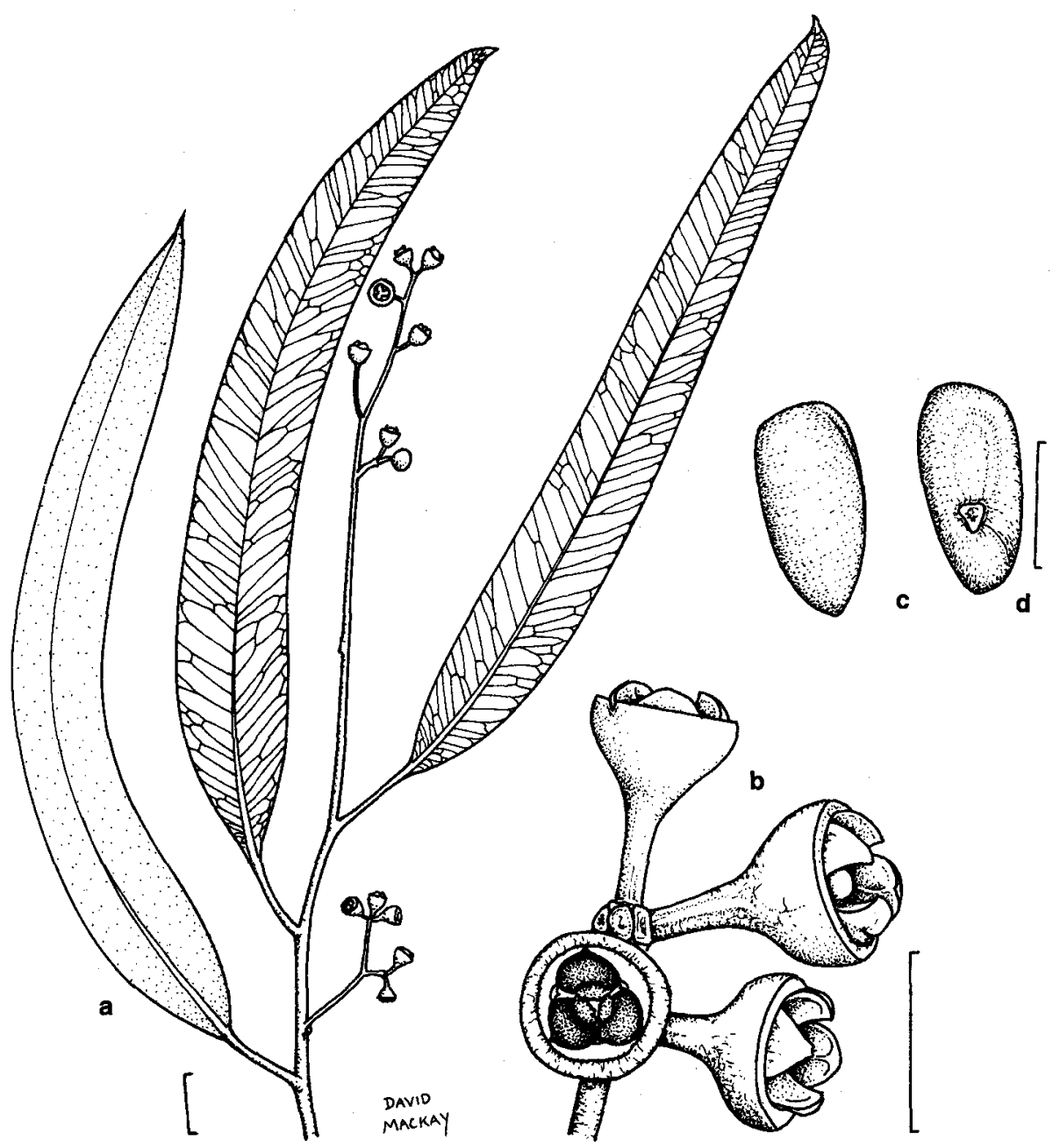

Figure 17. E. coolabah subsp. excerata. a., shoot with fruiting inflorescences. b., fruit. c., d., seeds (all from K. Hill $1185 \&$ L . Johnson). Scale bar: $\mathrm{a}=1 \mathrm{~cm} ; \mathrm{b}=5 \mathrm{~mm} ; \mathrm{c}, \mathrm{d}=1 \mathrm{~mm}$. 
19B. Eucalyptus coolabah Blakely subsp. excerata L. Johnson $\mathcal{E}$ K. Hill, subsp. nov.

Ab subspecie coolabah ramulis, foliis, alabastris et fructibus non glaucis; ab subspecie arida foliis adultis tenuibus et calyptra acuta; distinguitur.

TYPE: QuEENSLAND: Blowhard Creek, Charters Towers to Clermont road, K. Hill 1185 \& L. Johnson, 21.8.1984 (holo NSW; iso BRI, CANB, MEL).

Adult leaves chartaceous, green, non-glaucous. Buds and fruit non-glaucous. Calyptra double, outer shed early, inner acute, slightly longer than hypanthium (Figure 17).

Distinguished from subsp. coolabah by the non-glaucous leaves, buds and fruit, and from subsp. arida by the thin-textured adult leaves and the acute calyptra.

Restricted to the east of the range of the species, from the upper Darling River system (Moree to Goondiwindi) north through the western Darling Downs into the Fitzroy River system north of Rockhampton, and on to east of Einasleigh (Figure 16). Restricted to eastern drainage systems for the most part in the north of the range, although extending into some western headwaters. In the latter areas, this subspecies occurs along creeks in rolling country with narrower, somewhat sandier floodplains, and subspecies coolabah occurs on the flat, heavy soil plains.

Intergradation is extensive with subspecies coolabah where the ranges overlap, and extensive populations in these areas display a full range of variation between the two taxa. Hybrids are also known with E. crebra F. Muell., E. melanophloia F. Muell. (hybrids have been named E. bucknellii Cambage, E. rivularis Blakely and E. yagobiei Maiden), $E$. populnea F. Muell. (hybrids have been named E. populnea F. Muell. var obconica (Blakely) Cameron), E. largiflorens F. Muell., E. pilligaensis Maiden and E. albens Benth.

Selected SPECIMENS (from 38 examined): QueENSLAND: Reid River, 30 miles [48 km] S of Townsville, N. Daley 5, 24.2.1912 (NSW); $1 \mathrm{~km} \mathrm{~S}$ of Cape River crossing on Charters Towers-Clermont road, A.N. Rodd $4556 \&$ M. Hardie, 25.4.1985 (BRI, CANB, NSW); $47 \mathrm{~km}$ NNW of Clermont on Charters Towers road, A.N. Rodd 4560 \& M. Hardie, 26.4.1985 (BRI, CANB, NSW); Mackenzie River 14 miles [22 km] N of Duaringa, S.L. Everist 14, 28.1.1954 (BRI, NSW); West Rockhampton, W.N. Jaggard 1E2, 12.1911 (NSW); 4 miles [6.4 km] S of Wowan, N.H. Speck 2013, 18.5.1964 (CANB, NSW); 35 miles [56 km] N of Biloela, C.R. Dunlop, 25.5.1969 (NSW, CBG); Palm Tree Creek, $20 \mathrm{~km}$ N of Taroom, M.D. Crisp 2880, 7.6.1977 (BRI, CANB, CBG, NSW); $28.5 \mathrm{~km} \mathrm{~W}$ of turnoff to Chinchilla N of Jandowae, M.I.H. Brooker 7312, 6.5.1982 (CANB, NSW); Goondiwindi, R.B. McIntyre, 18.1.1912 (NSW). NEW SOUTH WALES: North Western Plains: near McIntyre River, Boggabilla, L.A.S. Johnson \& E.F. Constable NSW 32213, 9.11.1954 (NSW); New Angledool, A.B. Paddison, 2.1900 (NSW); Mookoo, near Mungindi, R.H. Cambage 4370, 19.12.1922 (NSW); Gundamaine, near Narrabri, H. Deane 131, 4.1885 (NSW); 50 miles [80 km] W of Narrabri, W.F. Blakely, 8.1936 (NSW).

The epithet is from the Latin ex, 'without, not', and cerata, 'waxed', in reference to the absence of evident wax (pruinosity or glaucousness).

CONSERVATION STATUS: Not considered to be at risk.

19C. Eucalyptus coolabah Blakely \& Jacobs subsp. arida (Blakely) L. Johnson \& K. Hill, comb. et stat. nov.

BASIONYM: Eucalyptus coolabah Blakely \& Jacobs var. arida Blakely, Key Eucalypts: 246 (1934).

TYPE Citation: 'Desert country from Cooper's Creek, S.A., to Doraminna, N.T.' ['Doraminna' is a typographical misinterpretation of Ooraminna.]

TYPE: SOUTH Australia: Kopperamana, Cooper Creek, H. Basedow 17, 11.1919 (lecto NSW 10046, here designated; iso BRI). 
Although not so designated in the protologue, this specimen was selected and annotated as 'Type' by Blakely in NSW.

Adult leaves coriaceous, non-glaucous. Buds and fruit non-glaucous. Calyptra double, outer shed early, inner hemispherical or broadly conical, as long as or slightly shorter than hypanthium. The anthers are also slightly larger than those of the other two subspecies.

This is the western subspecies, widespread in north-eastern South Australia, extending into far north-western N.S.W., south-eastern N.T. and western Queensland. This subspecies is often on sandy or gravelly creek lines through stony or sandy desert country (though on heavier soils than those occupied by the representative of $E$. camaldulensis Dehnh. sens. lat. in these regions); and is abundant through the 'Channel Country' along Coopers Creek.

Selected SPECimens (from 58 examined): QueENSLAND: 12 miles [19.2 km] $\mathrm{N}$ of 'Wooroona' homestead, G.M. Chippendale NT4998, 10.1.1966 (NSW, NT); Carandotta, SE of Urandangie, S.T. Blake 10195, 16.11.1935 (BRI, CANB, NSW, NT); $83 \mathrm{~km} \mathrm{E}$ of Winton-Hughenden road on Muttaburra road, M.I.H. Brooker 7860, 7.12.1982 (CANB, NSW); Glenormiston, A.C. Boyle, 28.1.1935 (BRI, NSW); $108 \mathrm{~km}$ from Quilpie on Thargomindah road, $R$. Johnston $461 \mathcal{E} \mathrm{J}$. Turner, 8.3.1981 (CANB, CBG, NSW). NEW SOUTH WALES: Far North Western Plains: $9.5 \mathrm{~km} \mathrm{~S}$ of 'Delalah House' towards Dribbling Bore, J. Pickard 2051, 25.3.1973 (NSW); $3 \mathrm{~km} \mathrm{~S}$ of Tindara, M.I.H. Brooker 6163, 24.3.1979 (CANB, NSW); Teilta Lake, M.I.H. Brooker 6159, 24.3.1979 (CANB, NSW). South Australia: Dalhousie Springs, 77 miles $[123 \mathrm{~km}] \mathrm{N}$ of Oodnadatta, D.E. Symon 3273, 12.2.1965 (ADW, K, NSW); $34 \mathrm{~km}$ along track to Moomba, $132 \mathrm{~km} \mathrm{~S}$ of Birdsville, $T$. O'Leary, 10.1985 (NSW); Poonina Waterhole, J.Z. Weber 9136, 5.9.1986 (AD, NSW); Cooper Creek at Innamincka, D.E. Symon 5734, 18.8.1968 (ADW, CANB, NSW); Neales River on Oodnadatta road, K. Hill 845, 846 \& L. Johnson, 8.7.1984 (NSW); $25 \mathrm{~km} \mathrm{SE}$ of William Creek, M.I.H. Brooker 9294, 22.5.1986 (CANB, NSW); Paisley Creek, c. $50 \mathrm{~km} \mathrm{~S}$ of William Creek on Marree road, $K$. Hill 842 \& L. Johnson, 8.7.1984 (NSW); Margaret River, c. $15 \mathrm{~km} \mathrm{SE}$ of Coward Springs railway, $K$. Chorney 971, 2.10.1978 (AD, NSW); Strzelecki Track $200 \mathrm{~km} \mathrm{~S}$ of Innamincka, T. O'Leary, 10.1985 (NSW); Kennebery Creek, $28 \mathrm{~km} \mathrm{~W}$ of Marree, K. Hill $839 \&$ L. Johnson, 8.7.1984 (AD, NSW, PERTH); $20 \mathrm{~km}$ from Hawkers Gate, in S.A., T. O'Leary, 7.10.1985 (NSW). NORTHERN TERRITORY: Deep Well road, 12 miles [19 km] S of Alice Springs, D.J. Nelson 1161, 21.12.1967 (NSW, NT); 3 miles [4.8 km] S of Spinifex Bore, Deep Well station, P.K. Latz 40, 31.12.1967 (NSW, NT); 76 miles [122 km] SW of Alice Springs, C.E. Carter, 7.5.1951 (NSW); $59.8 \mathrm{~km} \mathrm{E} \mathrm{of} \mathrm{Curtin}$ Springs, K. Hill $857 \&$ L. Johnson, 10.7.1984 (NSW).

CONSERVATION STATUS: Not considered to be at risk.

\section{Eucalyptus ophitica $L$. Johnson $\mathcal{E} K$. Hill, sp. nov.}

$\mathrm{Ab}$ E. fibrosa characteribus sequentibus differt: calyptra brevior, latior, rotundata; antherae minores; folia juvenilia angustiora.

TYPE: NeW SOUTH WALES: North Coast: $10.0 \mathrm{~km} \mathrm{~S}$ of Baryulgil on Grafton road $\left(29^{\circ} 18^{\prime} \mathrm{S}, 152^{\circ} 38^{\prime} \mathrm{E}\right)$, K. Hill 797 \& L. Johnson, 7.5.1984 (holo NSW; iso BRI, CANB, K, MEL, PERTH).

Tree to $10 \mathrm{~m}$ high. Bark persistent to smaller branches, hard, flaky 'ironbark'; smooth, whitish on branches less than c. $7 \mathrm{~cm}$ diam. Juvenile leaves disjunct, broad-lanceolate, rounded, to $15 \mathrm{~cm}$ long, $6 \mathrm{~cm}$ wide; petioles to $2.0 \mathrm{~cm}$ long. Adult leaves disjunct, similifacial, lanceolate to broad-lanceolate, obtuse or acute, $7-15 \mathrm{~cm}$ long, $1.3-3.2 \mathrm{~cm}$ wide; petioles to $2.8 \mathrm{~cm}$ long; lateral veins moderately spaced, regular, at $40-50^{\circ}$ to midrib; reticulum even, obscure; oil glands obscure; intramarginal vein continuous, distinct, $0.5-1.0 \mathrm{~mm}$ from margin. Inflorescences compound, terminal or axillary; umbellasters 3-7-flowered, sometimes somewhat irregular; peduncles terete, 2-11 mm long; pedicels 4-7 mm long, tapering into buds and fruit. Mature buds clavate, 8-10 $\mathrm{mm}$ long, 4-5 mm diam. Calyptra double; outer shedding early; inner hemispherical, 
broadly apiculate, as long as hypanthium, slightly wider than hypanthium. Fruit conical, convex, 4-5-locular, 5-7 mm long, 5-7 mm diam.; calyptra scar less than $0.1 \mathrm{~mm}$ wide; stemonophore flat, $0.2-0.4 \mathrm{~mm}$ wide; disc raised at $15-30^{\circ}$, ultimately incurved, $1.0-1.5 \mathrm{~mm}$ wide; valves broadly triangular, exserted, raised at $40-70^{\circ}$. Seeds subglossy, red-brown, rounded, elliptical, almost smooth; hilum ventral; chaff similar (Figure 18).

Distinguished from E. fibrosa F. Muell. by the hemispherical calyptra that is broader than the hypanthium (the calyptra is not broader than the hypanthium in $E$. fibrosa), and the broad-lanceolate juvenile leaves ( $E$. fibrosa has ovate juvenile leaves). The anthers of E. ophitica are also smaller than those of $E$. fibrosa.

SPeCiMENS EXAMINED: NeW SOUTH WALES: North Coast: serpentine country, upper Clarence River, C.I. Davison, 8.12.1942 (NSW); Baryulgil district, R.J. Turner, 7.1955 (NSW); $10.0 \mathrm{~km} \mathrm{~S}$ of Baryulgil on Grafton road, K. Hill 796, 798 \& L. Johnson, 7.5.1984 (NSW).

Distribution: New South Wales: North Coast, Baryulgil district (Figure 19).

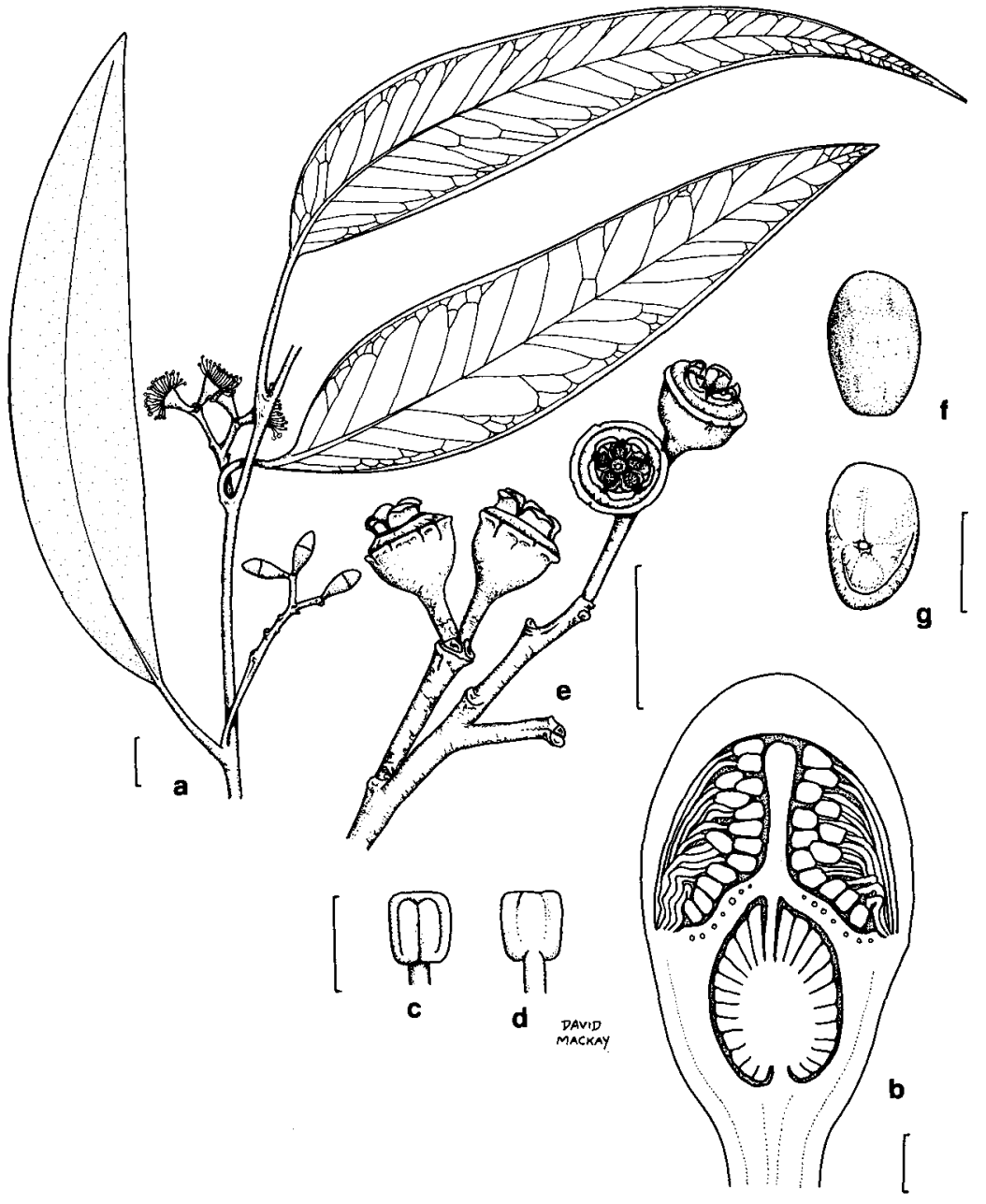

Figure 18. E. ophitica. a., shoot with buds and flowers. b., median section of bud. c., d., anthers. $\mathrm{E}$, inflorescence with fruit. f., g., seeds (a, e, f, g from K. Hill $797 \mathcal{E}$ L. Johnson, b, c, d from K. Hill $796 \&$ L. Johnson). Scale bar: $\mathrm{a}, \mathrm{e}=1 \mathrm{~cm} ; \mathrm{b}, \mathrm{f}, \mathrm{g}=1 \mathrm{~mm} ; \mathrm{c}, \mathrm{d}=0.5 \mathrm{~mm}$. 
ECOLOGY: Locally abundant in grassy woodland on skeletal red loamy soils over undulating to hilly serpentinite outcrops. Known only from outcrops of the Baryulgil serpentinite belt.

The epithet is from the Greek ophites, 'serpentine' (rock), referring to the substrate on which the species is found.

CONSERVATION STATUS: 2V-. Not known to occur on reserved lands, and under potential threat from pastoral activity. Further field study of population distribution is required.

21. Eucalyptus populnea F. Muell., J. Linn. Soc., Bot. 3: 93 (1859).

=E. populifolia Hook., Mitchell's Trop. Austral.: 204 (1848), non Desf. (1829).

TYPE CITATION: None cited. The plant was collected when Mitchell's expedition was in the vicinity of Mount Owen, Central Queensland.

TYPE: QueENSLAND: Mt Owen, T.L. Mitchell 336, 18.6.1846 (holo CGE, n.v.).

Maiden (Crit. Revis. Eucalyptus 3: 93) stated that Mitchell's specimen belonged to E. alba Reinw. ex Bl. [sens. lat.; = E. platyphylla F. Muell. sens. strict.]. However, Mt Owen is a considerable distance from the nearest occurrence of this species, and well within the range of E. populnea. Chippendale (1988) regarded the later illustration of this taxon by Hooker (Icon. Pl. t. $879(1851)$ ) as a distinct publication with a separate type, whereas we would regard this as an amplification of the earlier description using a more comprehensive specimen to compile the illustration.

[E. micrantha A. Cunn. ex Maiden, Crit. Revis. Eucalyptus 1: 340 (1908), in syn., nom. nud.; non DC. (1827).]

[E. polyanthemos Schauer var. populifolia F. Muell. ex Maiden, Crit. Revis. Eucalyptus 1: 340 (1908), in syn., nom. nud.]

Two geographic subspecies may be recognized in this taxon, one in the north of the range of the species and one in the south (Figure 20). Substantial intergradation occurs in the intermediate region.

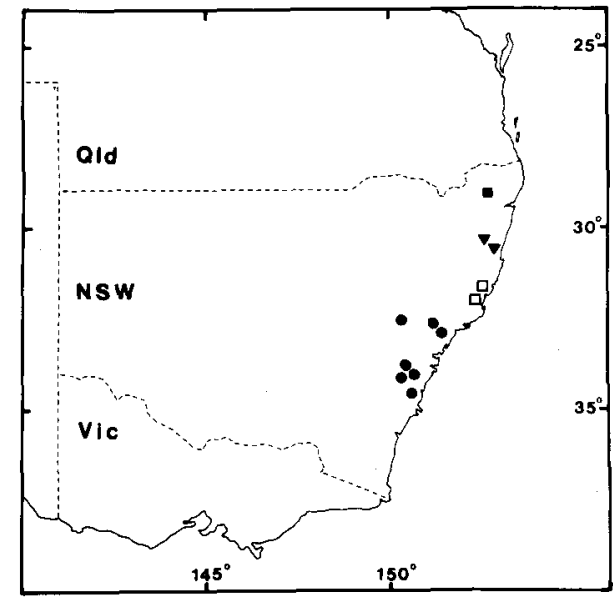

Figure 19. Distribution of E. ophitica (solid square), E. ancophila (triangle), E. rudderi (open square) and E. hypostomatica (circle). 


\section{Key to subspecies}

1 Fully adult leaves rounded

21A. subsp. populnea

1* Fully adult leaves acute 21B. subsp. bimbil

\section{A. Eucalyptus populnea $F$. Muell. subsp. populnea}

Tree to $20 \mathrm{~m}$ tall. Bark persistent to larger branches, fibrous-flaky ('box'), patchy grey and pale grey; smaller branches smooth, grey. Adult leaves ovate to orbicular or \pm deltoid, very glossy, rounded to emarginate, $4-10 \mathrm{~cm}$ long, 4-10 cm wide; petioles $1.8-4 \mathrm{~cm}$ long. Inflorescences simple, axillary, but often aggregated on leafless shoots; umbellasters 7-11-flowered; peduncles $4-10 \mathrm{~mm}$ long; pedicels $0-3 \mathrm{~mm}$ long. Buds ovoid, 3-4 mm long, 2-2.5 mm diam. Calyptra double, outer shed early, inner hemispherical, slightly shorter than hypanthium. Fruit cup-shaped to obconic, 3-4 $\mathrm{mm}$ long, 3-4 mm diam. Calyptra scar flat; disc depressed, valves enclosed.

Adult leaves ovate-orbicular, obtuse, rounded or emarginate. Petioles long, relatively slender. Buds and fruit small.

SELECTED SPECIMENS (from 39 examined): QUEENSLAND: Rockhampton, R. Simmons, 1903 (NSW); 'Gadwall', Alpha, G.H. Wood, 18.10 .1911 (NSW); 7 miles [11 km] W of Emerald, Adams 1286, 15.9.1964 (CANB, NSW); 2 miles [3.2 km] W of Dawson River, W of Moura, N.H. Speck 1898, 20.10.1963 (CANB, NSW); 0.5 miles $[0.8 \mathrm{~km}] \mathrm{S}$ of Gayndah on road to Wigton homestead, M.I.H. Brooker 3756, 29.8.1972 (CANB, NSW); Bendemere, S.L. Everist 4443, 8.7.1952 (NSW, BRI); 25 miles [40 km] ENE of Dalby on road to Kogan, S.L. Everist, 10.1969 (NSW, BRI); Leyburn, A.E.A. McMahon, 25.9.1911 (NSW).

This is the northern and eastern taxon, extending from the northern limit on about the Tropic of Capricorn south to the western Darling Downs. Extensive intergradation occurs with subsp. bimbil in the south of the range. Both taxa are characteristic of flat sites on fairly heavy red or brown clay-loams, not occurring however on the heaviest grey clay soils. There is also, at its northern limits in Queensland, a south-west to north-east belt of intergrades with the closely related E. brownii Maiden \& Cambage, which occurs on similar substrates.

CONSERVATION STATUS: Not considered to be at risk.

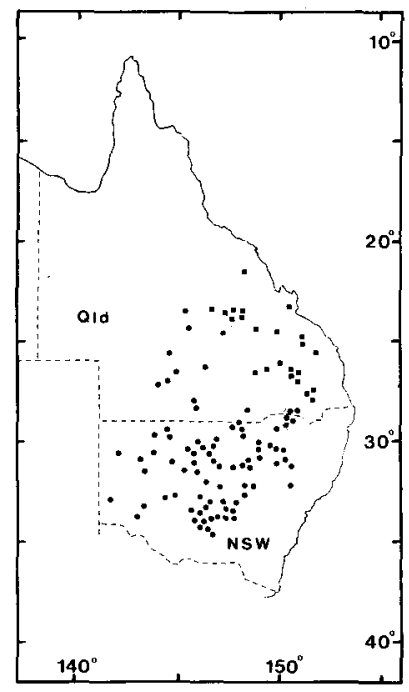

Figure 20. Distribution of E. populnea subsp. populnea (square), subsp. bimbil (solid circle) and intergrading forms (open circle). 
21B. Eucalyptus populnea $F$. Muell. subsp. bimbil L. Johnson $\mathcal{E}$ K. Hill, subsp. nov.

Folia adulta ovata, acuta. Petioli breviores crassioresque, alabastra fructusque majores quam eis subspeciei populneae.

TYPE: NEW SOUTH WALES: South Western Plains: $32 \mathrm{~km}$ NW of Rankin Springs towards Hillston, J.D. Turner $86 \mathcal{E}$ H. Vos, 12.9.1977 (holo NSW; iso CANB, MEL, AD, PERTH).

Tree to $25 \mathrm{~m}$ tall. Bark persistent to larger branches, fibrous-flaky ('box'), patchy grey and pale grey; smaller branches smooth, grey. Adult leaves broad-lanceolate to ovate, highly glossy, acute or apiculate, 5-12 cm long, 2-5 cm wide, petioles $0.9-3.5 \mathrm{~cm}$ long. Inflorescences simple, axillary, but often aggregated on leafless shoots; umbellasters 7-11-flowered; peduncles 4-10 mm long; pedicels $0-3 \mathrm{~mm}$ long. Buds ovoid, 3-5 $\mathrm{mm}$ long, 2-3 mm diam. Calyptra hemispherical, slightly shorter than hypanthium. Fruit cup-shaped to obconic, 3-5 mm long, 3-5 mm diam. Calyptra scar flat; disc depressed, valves enclosed.

Adult leaves broad-lanceolate to ovate, acute or apiculate. Petioles shorter and thicker than those of subsp. populnea. Buds and fruit generally larger than those of subsp. populnea.

Extensive intergrades between the subspecies occur in southern Queensland and adjoining N.S.W. Inland forms of both subspecies tend to be coarser in all parts.

Herbarium specimens in leaf only can be confused with E. behriana F. Muell., but are distinguishable by the smooth adult leaf margin in comparison to the finely irregular rough adult leaf margin of E. behriana. The latter is a mallee, with much less 'box' bark.

Local intergrading populations occur with $E$. largiflorens F. Muell., in sites intermediate between those occupied by the parent species.

Hybrids are known with E. coolabah subsp. excerata (hybrids = E. populnea F. Muell. var. obconica (Blakely) Cameron), E. sp. aff. drepanophylla F. Muell. ex Benth., E. crebra F. Muell. (hybrids $=E$. rariflora Blakely), E. melanophloia $\mathrm{F}$. Muell. (hybrids $=E$. beasleyi Blakely), E. intertexta R. Baker, E. microcarpa (Maiden) Maiden, E. pilligaensis Maiden and $E$. conica Deane \& Maiden.

SELECTED SPECiMENS (from 85 examined): QuEENSLAND: Barcaldine, H. Robinson, 9.10.1911 (NSW); c. $26 \mathrm{~km} \mathrm{~N}$ of Adavale, D.E. Boyland 8079, 10.10 .1979 (CANB, NSW, AD, MO, PRE, SP, BRI); 59 $\mathrm{km} \mathrm{S}$ of Quilpie towards Thargomindah, J. Turner $459 \&$ \& Johnston, 8.3.1981 (CANB, NSW, CBG); Mitchell Highway, $25 \mathrm{~km}$ S of Cunnamulla, A.N. Rodd $4579 \&$ \& M. Hardie, 29.4.1985 (NSW, BRI, CANB). NeW SOUTH WALES: North Western Slopes: $12 \mathrm{~km} E$ of Gunnedah on Oxley Highway, M.I.H. Brooker 6052, 22.1.1979 (CANB, NSW). Central Western Slopes: 1.2 miles [1.9 km] W of Peak Hill, R. Eakin 78, 1.12 .1970 (CANB, NSW); $10 \mathrm{~km} \mathrm{~N}$ of Wirrinya West $\left(33^{\circ} 39^{\prime} \mathrm{S}\right.$ $\left.147^{\circ} 41^{\prime} \mathrm{E}\right), K$. Wells \& J. Curtis 53, 19.3.1973 (CANB, NSW). South Western Slopes: halfway between Narrandera and Leeton, $K$. Wells 8, 32, 27.4.1972 (CANB, NSW). North Western Plains: near Whalan Creek, c. 8 miles [12 km] SW of Boggabilla, Walker ANU 302, 27.5.1962 (CANB, NSW); Lightning Ridge, E.F. Constable NSW 19251, 28.5.1951 (NSW); Bourke to Nyngan, N. Hall H74/14, 12.6.1974 (CANB, NSW); $1 \mathrm{~km}$ E of Byrock, K. Wells 106, 15.7.1974 (CANB, NSW); 30.5 km SSE of Coonamble on Gilgandra road, S.L. Everist S22, 7.12.1969 (NSW, BRI). South Western Plains: $32 \mathrm{~km} \mathrm{NW}$ of Rankins Springs towards Hillston, J.D. Turner $86 \&$ H. Vos, 12.9.1977 (CANB, NSW). Far North Western Plains: Yantabangee Creek, $65 \mathrm{~km}$ direct NE of White Cliffs, L.A.S. Johnson 8468, 16.5.1979 (NSW). Far South Western Plains: 'Pan Ban' station, ENE of Pooncarie, J.C. Noble \& R.A. Bawden, 18.7.1979 (NSW).

DISTRIBUTION: Extending from around Barcaldine in central Queensland to the lower Darling River in south-western N.S.W., on heavy soil flats, although not on the heaviest grey cracking clays (Figure 20).

The subspecific epithet is from the aboriginal (Wiradhuri) name bimbil, and recalls the 
widely used popular name of this species, 'bimble box', especially in New South Wales where it is represented by this subspecies.

CONSERVATION STATUS: Not considered to be at risk.

\section{Eucalyptus hypostomatica $L$. Johnson $\mathcal{E}$ K. Hill, sp. nov.}

$\mathrm{Ab}$ E. rudderi foliis adultis latioribus hypostomaticisque distinguitur.

Type: New SOUTH Wales: Central Coast: 0.3 miles [0.5 km] from Lumbys Road on Langans Road, Correbare State Forest $\left(33^{\circ} 00^{\prime} \mathrm{S} 151^{\circ} 15^{\prime} \mathrm{E}\right)$, M.I.H. Brooker 4624, 11.11.1974 (holo NSW; iso CANB).

Tree to $30 \mathrm{~m}$ tall. Bark persistent, finely tessellated, dark grey, shortly fibrous-flaky ('box') on trunk and sometimes larger branches; branches smooth, grey. Juvenile leaves disjunct; broad-lanceolate to ovate, bright green, petiolate, strongly discolorous, to 10 $\mathrm{cm}$ long, $5 \mathrm{~cm}$ wide. Adult leaves disjunct, lanceolate to broad-lanceolate or ovate, acute or acuminate, glossy green, strongly discolorous (hypostomatic), 8-18 cm long, 1.0-3.0 $\mathrm{cm}$ wide; petioles flat, 10-18 mm long; lateral veins well-spaced, regular, finely regularly reticulate between, at $30-50^{\circ}$ to midrib; intramarginal vein distinct, \pm looped, 0.5-2 mm from margin. Inflorescences compound, comprising 7-flowered umbellasters aggregated on short lateral or terminal shoots; peduncles 3-8 $\mathrm{mm}$ long; pedicels $1-2$ $\mathrm{mm}$ long. Buds ovoid, 4-5 $\mathrm{mm}$ long, 2-3 mm diam. Calyptra double; outer shedding early; inner much shorter than hypanthium, broadly conical, obtuse. Stamens regularly inflexed, outer whorls longer and infertile; anthers adnate, cuboid, oblique, dehiscing through terminal pores. Fruit ovoid to obconic, mainly 3-locular, 4-5 mm long, 3-4 mm diam.; stemonophore persistent; disc vertically depressed; valves deeply enclosed.

Distinguished from E. rudderi Maiden by the broad-lanceolate to ovate, hypostomatic adult leaves.

SeleCted SPECiMENS (from 23 examined): New South WALES: North Coast: Pokolbin State Forest $\left(32^{\circ} 52^{\prime} \mathrm{S} 151^{\circ} 09^{\prime} \mathrm{E}\right)$, M.I.H. Brooker 4628, 12.11.1974 (CANB, NSW). Central Coast: Mt Warrawalong, Wattagan State Forest $\left(33^{\circ} 02^{\prime} \mathrm{S} 151^{\circ} 21^{\prime} \mathrm{E}\right)$, L. Johnson NSW 135699, 23.11.1959 (NSW); 11 miles [17.6 km] E of Laguna, E.F. Constable NSW 56649, 25.5.1960 (NSW); Lacys Creek, Lower Burragorang Valley, J. Kellow 202, 18.5.1960 (NSW); Nattai River, downstream from Wanganderry Creek ( $\left.34^{\circ} 18^{\prime} \mathrm{S} 150^{\circ} 21^{\prime} \mathrm{E}\right)$, I. Olsen 2170, 29.6.1974 (NSW); Kangaroo Valley, M.N. Fackender NSW 135704, 1965 (NSW).

Distribution: Scattered, in isolated populations from the Pokolbin district of N.S.W. south to Kangaroo Valley, and inland as far as Widdin Brook in the upper Hunter Valley (Figure 19).

ECOLOGY: A component of grassy or sclerophyll forests on steep sites in subcoastal ranges.

The epithet is from the Greek hypo-, 'beneath', and stoma, 'a mouth', in reference to the hypostomatic adult leaves.

CONSERVATION STATUS: 3R-. Although fairly widespread, this species occurs in small and isolated stands. Many occurrences are in State Forest areas, and relatively secure in the short term.

\section{Eucalyptus magnificata L. Johnson \& $K$. Hill, sp. nov.}

$\mathrm{Ab}$ E. baueriana foliis, alabastris, fructibus majoribus crassioribusque distinguitur.

TYPE: NeW SOUTH WALES: Northern Tablelands: Enmore, 18 miles [29 km] E of Uralla, R.H. Cambage 3776, 18.3.1917 (holo NSW) 
Tree to $8 \mathrm{~m}$ tall. Bark persistent, grey, shortly fibrous-flaky ('box') on trunk and sometimes larger branches; branches smooth, grey. Juvenile leaves disjunct, orbicular, greygreen, petiolate, concolorous, to $8 \mathrm{~cm}$ long, $5 \mathrm{~cm}$ wide. Adult leaves disjunct, lanceolate to broad-lanceolate or ovate, acute, dull glaucous or grey, concolorous, $5-10 \mathrm{~cm}$ long, 4-6 $\mathrm{cm}$ wide; petioles slender, $15-30 \mathrm{~mm}$ long; lateral veins well-spaced, regular, at $30^{\circ}-50^{\circ}$ to midrib, finely regularly reticulate between; intramarginal vein distinct, \pm looped, 1-3 mm from margin. Inflorescences compound, comprising 7-flowered umbellasters aggregated on short lateral or terminal shoots; peduncles terete, $7-13 \mathrm{~mm}$ long; pedicels thick, terete, 2-4 mm long. Buds glaucous, ovoid, 6-7 mm long, 3-4 mm diam. Calyptra double, outer shedding early. Inner shorter and narrower than hypanthium, conical, obtuse. Stamens regularly inflexed, outer whorls longer and infertile. Anthers adnate, cuboid, oblique, dehiscing through terminal pores. Fruit glaucous, obconic, sometimes split around rim, 3-4-locular, 7-10 mm long, 6-9 mm diam. Stemonophore persistent; disc vertically depressed. Valves deeply enclosed.

Distinguished from E. baueriana Schauer by the larger, coriaceous adult leaves (to $8 \mathrm{~cm}$ long, $5 \mathrm{~cm}$ wide in E. baueriana), and the larger, coarser buds (to $6 \mathrm{~mm}$ long, $3 \mathrm{~mm}$ diam. in E. baueriana) and fruit (to $7 \mathrm{~mm}$ long, $6 \mathrm{~mm}$ diam. in E. baueriana).

SELECTED SPECIMENS (from 8 examined): QUEENSLAND: Cottonvale Road, $1.3 \mathrm{~km} \mathrm{~S}$ of Dalveen, $P$. Holzworth 4a, 13.9.1983 (NSW); 13 miles [21 km] from Stanthorpe, A. Murphy, 3.1904 (NSW). NEW SOUTH WALES: Northern Tablelands: Ferryman area, 25 miles $[40 \mathrm{~km}]$ E of Hillgrove, $J$. Battarbee NSW 30906, 12.1954 (NSW, K, BRI); Hillgrove, outskirts of town, R.W. Jessup \& M. Gray 1420, 5.1952 (NSW).

DisTRIBUTION: Known from scattered populations east and south-east of Armidale, and near Stanthorpe (Figure 21).

ECOLOGY: Locally frequent in open grassy woodland on relatively infertile sandy podsols.

The epithet is from the Latin magnificatus, 'magnified', in reference to the larger leaves, buds and fruits than those of related taxa.

CONSERVATION STAtus: $3 \mathrm{~V}$-. Although the total range is not small, this species occurs in

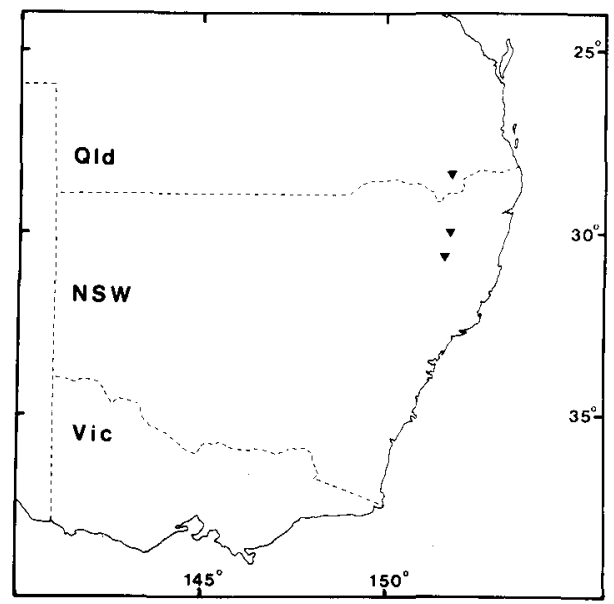

Figure 21. Distribution of E. magnificata. 
scattered populations, most of which are in productive grazing country and under considerable long-term threat.

24. Eucalyptus polyanthemos Schauer, in Walp., Rep. Bot. Syst. 2, Suppl. 1: 924 (1843).

TYPE CitATION: 'Bathurst. - A. Cunn. Herb. no. 136/1822!'

TYPE: holo W (n.v.); iso BM(n.v.), K.

Two subspecies are recognised on the basis of regional differences in bark type. Both occur over a wide range, with a limited zone of intergradation where the ranges adjoin (Figure 22).

\section{Key to subspecies}

1 Bark patchily adherent or smooth on the trunk, shedding in large scales 24A. subsp. polyanthemos

1* Bark persistent to middle branches, 'box' 24B. subsp. vestita

\section{A. Eucalyptus polyanthemos Schauer subsp. polyanthemos}

= Eucalyptus ovalifolia R. Baker, Proc. Linn. Soc. New South Wales 25: 680 (1901).

TYPE CitATION: 'Hab. - Bathurst, Rylstone and Camboon (R.T. Baker); Hargraves (A.A. Sutton); Gerogery (L.Mann).'

TyPe: New South WALes: Cow Flat, Bathurst, R.T. Baker, 10.2.1901 (lecto NSW).

Lectotype designated by Maiden (Crit. Revis. Eucalyptus 2: 132). Baker had annotated a specimen with the locality of 'Bylong' as Type, but as this locality was not cited in the protologue it can have no significance. Included in E. polyanthemos by Maiden (Crit. Revis. Eucalyptus 2: 109, 111).

$=$ E. ovalifolia R. Baker var. lanceolata R. Baker \& H.G. Smith, Res. Eucalypts: 124 (1902).

TYPE CitATION: 'Habitat. - Camboon, Rylstone (R.T.B.), Hargraves (A.A. Sutton), Wellington, New South Wales.'

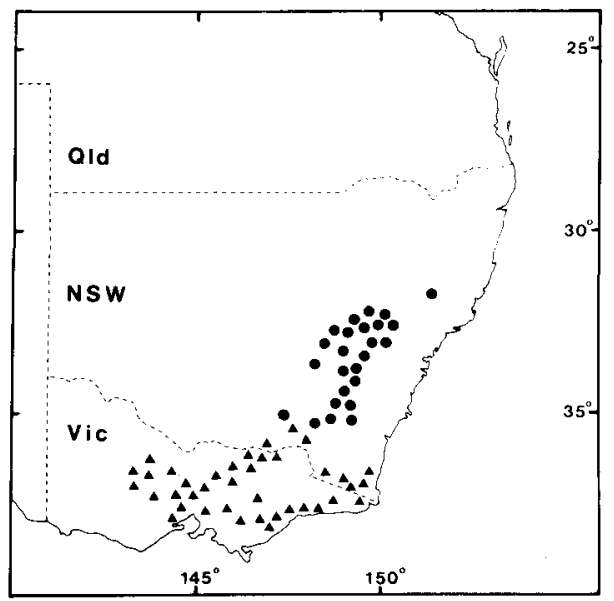

Figure 22. Distribution of E. polyanthemos subsp. polyanthemos (circle) and subsp. vestita (triangle). 
TYPE: NEW SOUTH WALES: Camboon, N of Rylstone, R.T. Baker NSW 19153, 10.10.1893 (lecto NSW, here designated). This specimen is one of several from this locality endorsed with the varietal name by Baker, whereas none from the other cited localities are so endorsed. The specimen bears leaves, buds and flowers. Included in E. polyanthemos by Maiden (Crit. Revis. Eucalyptus 2: 111).

Bark mostly smooth, sometimes irregularly persistent on trunk. Adult leaves broadlanceolate or ovate, similifacial.

The two subspecies show a zone of intergradation around Tumut. Sporadic hybrids are found with E. conica Deane \& Maiden in the Gulgong-Ulan district (Central Western Slopes).

Selected SPECimens (from 134 examined): NeW South Wales: Central Tablelands: Mullions Range, 14 miles [22 km] NNE of Orange, R. Coveny 4164, 15.4.1972 (NSW); Capertee, J.L. Boorman 7, 11.1900 (NSW); Abercrombie Caves, E.F. Constable NSW 39826, 21.3.1955 (NSW). Southern Tablelands: 3 miles [5 km] NW of Gundaroo, L.G. Adams 1910, 28.6.1967 (CANB, NSW, BRI, K, L); Bungendore road, near Captains Flat turnoff, L. Burgess CBG 030870, 24.8.1969 (CBG, NSW); Black Mountain Reserve, A.C.T., R. Coveny 11513 \& P. Hind, 18.1.1983 (CANB, K, NSW). Central Western Slopes: Sempill Creek, on Tomalla road, L. Johnson NSW 30070, 30.11.1954 (NSW); Stuart Town, J.L. Boorman 1, 6.1900 (NSW); Grenfell district, A.H. Lawrence, 9.1915 (NSW). South Western Slopes: Burrinjuck, R.H. Cambage 1912, 25.1.1908 (NSW); Wolongawah, Tumut, W.A.W. de Beuzeville, 6.9.1916 (NSW).

Distribution: Western parts of the Central and Southern Tablelands, and higher eastern parts on the Central and South Western Slopes, with an outlying population in the upper Hunter River valley (Figure 22).

ECOLOGY: Open woodland on poor, shallow soils on rocky, sloping sites.

CONSERVATION STATUS: Not considered to be at risk.

24B. Eucalyptus polyanthemos Schauer subsp. vestita $L$. Johnson $\mathcal{E}$ K. Hill, subsp. nov.

Cortex asper in trunco et saepe in ramis persistens.

TYPE: VictoriA: Kinglake Road near St Andrews, P. Carolan, 14.3.1965 (Holo NSW).

Bark persistent on trunk and larger branches, compact shortly fibrous-flaky with whitish patches ('box' bark).

Limited intergradation occurs with $E$. baueriana in the south of the range, in central Gippsland and west of Melbourne.

Selected SPECIMENS (from 72 examined): NeW South Wales: South Coast: Allan Brook Road, Yambulla State Forest, A. Nunnink \& R. Shiels 371, 3.2.1981 (NSW). Southern Tablelands: near Ingebyra, N of Snowy-Jacobs River junction, G.L. Vidler, 22.5.1958 (NSW); Merriangah station, near Bombala, D.J. Boland 2067 \& L. Thompson, 22.8.1984 (CANB, NSW). South Western Slopes: $17.8 \mathrm{~km}$ SW of Tarcutta towards Holbrook, G.M. Chippendale 1402 \& M.J. Brennan, 25.7.1975 (CANB, NSW); Jindera, near Albury, A. Briesl per E.J. McBarron 15399, 12.6.1968 (NSW). VICTORIA: Reeve Road, W of Orbost ( $37^{\circ} 35^{\prime}$ ' $\left.148^{\circ} 16^{\prime} \mathrm{E}\right)$, M.I.H. Brooker 6813, 16.1.1980 (CANB, NSW); Wattle Circle Road ( $\left.37^{\circ} 27^{\prime} \mathrm{S} 147^{\circ} 50^{\prime} \mathrm{E}\right)$, A.C. Beauglehole 37102, 27.2.1971 (NSW); $34 \mathrm{~km}$ W of Bairnsdale on road to Sale, M.I.H. Brooker 6841, 17.1.1980 (CANB, NSW); Dawson Road $\left(38^{\circ} 01^{\prime} \mathrm{S} 146^{\circ} 12^{\prime} \mathrm{E}\right)$, M.I.H. Brooker 6984, 30.9.1981 (CANB, NSW); $3.0 \mathrm{~km}$ S of Stockyard Creek, Hume Highway E of Chiltern, K. Hill 1733A, B, L. Johnson \& K. Wilson, 11.3.1986 (NSW); Glenrowan turnoff, Myrtleford to Wangaratta road, M.I.H. Brooker 4367, 12.2.1974 (CANB, NSW); 18 miles [29 km] NNE of Bendigo, E.F. Constable 5252, 23.10.1964 (NSW); $3.7 \mathrm{~km} \mathrm{E} \mathrm{of} \mathrm{St}$ Arnaud towards Avoca, K. Hill 1627, L. Johnson \& K. Wilson, 6.3.1986 (NSW); 22 miles [35 km] from Benalla towards Mansfield, M.E. Phillips 17, 19.10.1971 (NSW, CBG); $11 \mathrm{~km}$ from Heathcote towards Tooboora, M.I.H. Brooker 5977, 5978, 24.8.1978 (CANB, NSW, MEL); Long 
Forest road, Melton district, M.I.H. Brooker 6994, 1.10.1981 (CANB, NSW).

DISTRIBUTION: Mainly on undulating country in central Victoria, extending a short distance into New South Wales near Albury, with an outlying population near Bombala. It also extends through drier valleys in Gippsland onto somewhat drier ridge country in East Gippsland and the far South Coast of N.S.W. (Figure 22).

ECOLOGY: A woodland tree on poor, shallow soils, on slopes or, in Victoria, sometimes almost level country.

The epithet is from the Latin vestitus, 'clothed', referring to the persistent bark.

CONSERVATION STATUS: Not considered to be at risk.

25. Eucalyptus paniculata Sm., Trans. Linn. Soc. 3: 287 (1797).

TYPE CiTATION: 'My specimens were gathered at Port Jackson by Mr. David Burton, and I received them from Sir Joseph Banks's herbarium.'

Type: New South Wales: Port Jackson, D. Burton (holo LINN; iso BM).

Tree to $50 \mathrm{~m}$ tall. Bark persistent, corky and heavily kino-impregnated ('ironbark'). Juvenile leaves ovate, glossy dark green, disjunct, petiolate, discolorous, to $8 \mathrm{~cm}$ long, 4 $\mathrm{cm}$ wide. Adult leaves disjunct, lanceolate to broad-lanceolate, acuminate, glossy dark green, strongly discolorous, $9-15 \mathrm{~cm}$ long, $1.2-3.2 \mathrm{~cm}$ wide; petioles slender, $10-20$ $\mathrm{mm}$ long; lateral veins well-spaced, regular, at $40-50^{\circ}$ to midrib, finely regularly reticulate between; intramarginal vein distinct, \pm looped, 1-2 $\mathrm{mm}$ from margin. Inflorescences compound, comprising 7-flowered umbellasters aggregated on short lateral or terminal shoots; peduncles 7-18 mm long; pedicels quadrangular, 4-11 mm long. Buds shortly fusiform, usually slightly 3 - or 4-angled, 6-9 mm long, 4-5 mm diam. Calyptra double; outer shedding early; inner shorter and narrower than hypanthium with a distinct constriction at the junction, conical, acute. Stamens regularly inflexed, outer whorls longer and infertile; anthers adnate, cuboid, oblique, dehiscing through terminal pores. Fruit obconical to ovoid, 4-5-locular, 6-8 mm long, 6-9 mm diam.; stemonophore persistent; disc vertically depressed; valves deeply enclosed. Seeds ovoid, mid-brown, shallowly reticulate, hilum ventral; chaff mid-brown.

Two subspecies may be recognised in E. paniculata. Much of the material from the North Coast of New South Wales previously included in E. paniculata is separated as several new taxa (see below). E. fergusonii $R$. Baker is also recognised as a distinct species. Study of this group continues, and additional new taxa will be recognised in southern Queensland.

\section{Key to subspecies}

1 Adult leaves hypostomatic 25A. subsp. paniculata

1* Adult leaves amphistomatic 25B. subsp. matutina

\section{A. Eucalyptus paniculata $S m$. subsp. paniculata}

= Eucalyptus nanglei R. Baker, J. \& Proc. Roy. Soc. New South Wales 51: 48 (1917).

TYPE CITATION: 'Localities at present known to me are Morriset, Stroud, Bulladelah [sic], Woy Woy, Lindfield, Nowra.'

TYPE: 'Lindfield and Nowra', R.T. Baker \& L.G. Irby NSW 222254 (lecto NSW, here designated). The only specimens that can be related to Baker's protologue are three small pieces in a single folder, labelled 'E. nanglei / Lindfield \& Nowra / R.T.B. \& L.G. Irby'. This sheet has a later annotation of 'Rec. $27.5 .20^{\prime}$ by J.H. Maiden. The piece with the attached label and bearing leaves, buds and flowers is here designated as 
Lectotype, although the collection site cannot be further clarified.

Small to very tall forest tree (to $50 \mathrm{~m}$ tall). Juvenile leaves ovate. Adult leaves fully hypostomatic except for a narrow band of scattered stomata along the midrib of the adaxial surface.

Hybrids occur with E. moluccana Roxb., E. fergusonii R. Baker, E. siderophloia Benth. and E. bosistoana F. Muell.

SELECTED SPECIMENS (from 122 examined): New SOUTH WALES: North Coast: $5 \mathrm{~km} \mathrm{~N}$ of Bulahdelah on Pacific Highway, M.I.H. Brooker 7802, 1.12.1982 (CANB, MEL, NSW, PERTH); Kotara, SW of Newcastle, R.W. Earp, 14.4.1954 (NSW). Central Coast: between Avoca Beach and Copacabana, D.J. McGillivray 1214, 3.7.1965 (NSW); Hornsby, near Berowra bridge, W.F. Blakely, 6.1915 (NSW); $1.5 \mathrm{~km}$ from Sir Bertram Stephens Drive on road to Garie Beach, M.D. Crisp 7791 \& P. Weston, 21.4.1986 (AD, CBG, MEL, NSW). South Coast: 10 miles [16 km] S of Nowra, R.D. Johnston \& H. Vos FRI 13466, 1.11.1965 (CANB, NSW); Boyne State Forest, 4 miles [6.4 km] N of Batemans Bay, L. Walker NSW 154351, 11.1917 (NSW); $6.7 \mathrm{~km} \mathrm{~N}$ of Tilba Tilba, M.I.H. Brooker 6644, 12.11.1979 (CANB, NSW). Central Tablelands: 3 miles [5 km] N of Penrose, W.F. Blakely $\mathcal{E}$ G. Butt, 30.1.1938 (NSW). Central Western Slopes: Glenbawn Catchment, upper Hunter River, per A.R. Tewksbury, 3.1950 (NSW).

DISTRIBUTION: The subcoastal range country of N.S.W. from north of the Manning River south to near Bega, extending into the eastern tablelands country in parts. One record exists from the eastern edge of the upper Hunter Valley, Central Western Slopes (Figure 23).

ECOLOGY: A tree of wet to somewhat dry sclerophyll forests, usually on deeper, often somewhat clayey soils in more favourable sites.

CONSERVATION STATUS: Not considered to be at risk.

25B. Eucalyptus paniculata $S m$. subsp. matutina $L$. Johnson $\mathcal{E} K$. Hill, subsp. nov.

A subspecie paniculata foliis adultis per tota pagina adaxiali stomata sparsiuscule ferentibus distinguitur.

TYPE: NEW SOUTH WALES: North Coast: Tomaree Headland, towards top of ridge to east of hospital, K. Hill 759 \& L. Johnson, 3.5.1984 (holo NSW; iso BRI, CANB, MEL).

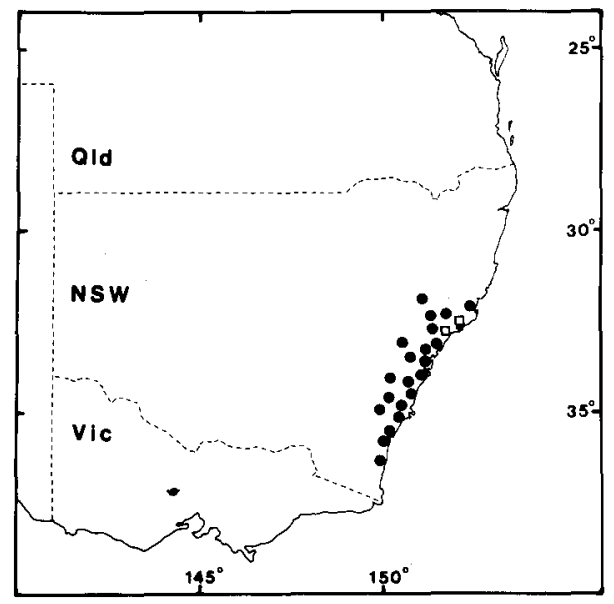

Figure 23. Distribution of E. paniculata subsp. paniculata (circle) and subsp. matutina (open square). 
Small tree (to $15 \mathrm{~m}$ tall), sometimes dwarfed to a mallee form. Adult leaves weakly amphistomatic, i.e. with a regular scattering of stomata over the adaxial surface, but at much lower densities than those on the abaxial surface.

Distinguished by the amphistomatic adult leaves.

Selected SPecimens (from 23 examined): New SOuth Wales: North Coast: Yacaabah, Port Stephens, D.F. Blaxell 2081, 16.5.1984 (NSW); Stephens Peak, Port Stephens, J. Benson, 2.1981 (NSW); Box Beach, Nelson Bay, L.A.S. Johnson 9004-9012, 20.4.1984 (NSW); 3 km S of Glebe Road, S of Newcastle, M.I.H. Brooker 7798, 1.12.1982 (CANB, NSW).

DISTRIBUTION: Known from a few populations in the Port Stephens district and south of Newcastle (Figure 23).

ECOLOGY: Locally abundant on coastal headlands, near-coastal hills and beach dunes in the area immediately north and south of Port Stephens, with a single record from south of Newcastle. In other regions populations near the sea appear to belong to the hypostomatic subsp. paniculata.

The epithet is from the Latin matutinus, 'of the morning', in allusion to the easterly distribution.

CONSERVATION STATUS: 2V-. Further study is required to delimit the populations of this taxon.

26. Eucalyptus fergusonii $R$. Baker, J. \& Proc. Roy. Soc. New South Wales 51: 415 (1917).

Type CITATION: 'Geographical Range. - Bulladelah [sic] and Wingello.'

TYPE: NeW SOUTH WALES: Bulladelah [= Bulahdelah], L.C. Maxwell, 10.1916 (lecto NSW 222250, here designated).

This specimen represents the form with long pedicels, 4-angled fruit and amphistomatic leaves that Baker had in mind when drawing up his description. Other specimens relating to the citation represent typical $E$. paniculata and intergrades with it.

[E. terminalis Sieb. ex Benth., Fl. Austral. 3: 212 (1867), in syn., nom. nud., nec F. Muell. (1859), nec Britten (1901).]

Tree to $30 \mathrm{~m}$ tall. Bark persistent, corky and heavily kino-impregnated ('ironbark'). Juvenile leaves ovate, glossy dark green, disjunct, petiolate, strongly discolorous, to 13 $\mathrm{cm}$ long, $6 \mathrm{~cm}$ wide. Adult leaves disjunct, lanceolate to broad-lanceolate, acuminate, glossy dark green, strongly discolorous, $8-16 \mathrm{~cm}$ long, $1.5-3.2 \mathrm{~cm}$ wide; petioles slender, 9-22 mm long; lateral veins well-spaced, regular, at $30-50^{\circ}$ to midrib, finely regularly reticulate between; intramarginal vein distinct, \pm looped, 1-2 $\mathrm{mm}$ from margin. Inflorescences compound, comprising 7-flowered umbellasters aggregated on short lateral or terminal shoots; peduncles 6-18 mm long; pedicels 6-17 mm long. Buds fusiform, distinctly 4-angled, 8-13 $\mathrm{mm}$ long, 5-6 $\mathrm{mm}$ diam. Calyptra double; outer shedding early; inner shorter and narrower than hypanthium with a distinct constriction at the junction, conical, acute. Stamens regularly inflexed, outer whorls longer and infertile; anthers adnate, cuboid, oblique, dehiscing through terminal pores. Fruit quadrangular, ovoid to obconical, 4-5-locular, 7-13 mm long, 5-10 mm diam.; stemonophore persistent; disc vertically depressed; valves deeply enclosed. Seeds ovoid, dark brown, shallowly reticulate, hilum ventral; chaff brown.

E. fergusonii has previously been regarded as a form of E. paniculata (Pryor \& Johnson $1971)$. The prime distinguishing character is the strongly 4 -angled fruits of $E$. fergusonii, although substantial interbreeding appears to occur in areas where the two are sympatric (see below). 
Two subspecies may be recognised in E. fergusonii on the basis of regional differences in stomatal distribution in adult leaves.

\section{Key to subspecies}

1 Adult leaves amphistomatic; fruit obconical 26A. subsp. fergusonii

1* Adult leaves hypostomatic; fruit ovoid 26B. subsp. dorsiventralis

\section{A. Eucalyptus fergusonii $R$. Baker subsp. fergusonii}

Adult leaves amphistomatic (but distinctly discolorous). Buds 8-10 mm long. Fruit obconical, 7-11 mm long.

An uncommon taxon, all known occurrences of which are associated with, or not far from, stands of E. paniculata subsp. paniculata. Extensive interbreeding occurs, and the $E$. fergusonii is apparently disappearing through assimilation of genetic material from $E$. paniculata. In areas where the two are sympatric, E. fergusonii is readily distinguished by the amphistomatic leaves combined with the fruit character. However, E. paniculata may have amphistomatic leaves in the area east of the range of $E$. fergusonii ( $E$. paniculata subsp. matutina), and E. fergusonii has hypostomatic leaves in areas to the west of the range of E. paniculata (E. fergusonii subsp. dorsiventralis).

Selected SPECIMENS (from 11 examined): New SOUTH WALES: North Coast: Pacific Highway, $3 \mathrm{~km}$ $\mathrm{N}$ of Karuah, J.T. Waterhouse 9503 \& K.L. Wilson, 24.8 .1979 (NSW); $7.2 \mathrm{~km}$ from Seahampton on Sugarloaf road, K. Hill 752 \& L. Johnson, 3.5.1984 (BRI, CANB, NSW); Wattagan Road, at N gate into State Forest from Quorrobolong, K. Hill 748 \& L. Johnson, 2.5.1984 (NSW). Central Coast: Morisset, R.T. Baker (NSW).

DisTRIBUTION: Very sporadic, represented by collections from Bulahdelah to Morisset (Figure 24).

ECOLOGY: A component of dry to rather wet sclerophyll forests. It is difficult to perceive any clear difference in habitat from that of E. paniculata.

CONSERVATION STATUS: 3R-. Further study is required to delimit the populations of this taxon. This subspecies appears to be hybridising extensively with $E$. paniculata subsp. paniculata, and may be at risk of becoming genetically 'submerged' within the latter taxon.

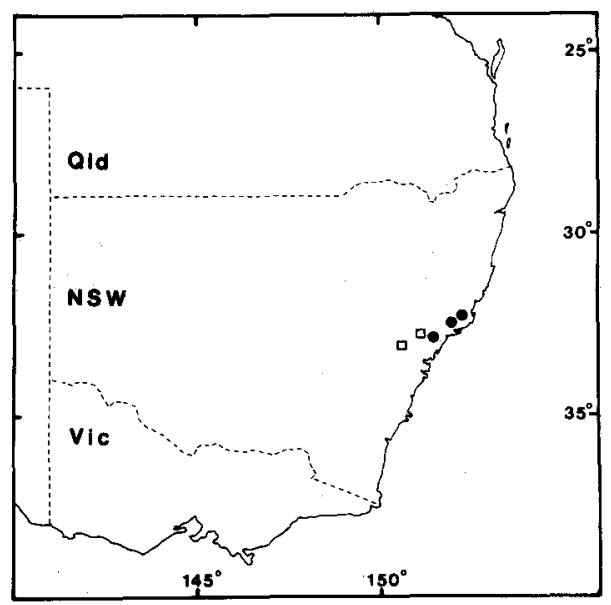

Figure 24. Distribution of E. fergusonii subsp. fergusonii (circle) and subsp. dorsiventralis (open square). 
26B. Eucalyptus fergusonii $R$. Baker subsp. dorsiventralis $L$. Johnson $\&$ K. Hill, subsp. nov.

A subspecie fergusonii foliis adultis sine stomatibus dispersis in pagina adaxiali distinguitur.

TYPE: New South Wales: North Coast: Old Convict Road, $5.5 \mathrm{~km}$ due $\mathrm{W}$ of Paynes Crossing bridge, K. Hill 2783 \& L. Stanberg, 3.5.1988 (holo NSW; iso PERTH, CANB, BRI, MEL, AD).

Distinguished by the hypostomatic adult leaves, the longer buds (10-13 $\mathrm{mm}$ long), and the longer, ovoid fruit (10-13 $\mathrm{mm}$ long).

Selected SPeCimens (from 5 examined): NeW South Wales: North Coast: Paynes Crossing, $J$. Simpson, 7.1987 (NSW); Wollombi, R. Story 6624, 1.9.1959 (NSW). Central Coast: above Junction of Wollemi Creek and Colo River, I.S. Olsen 17, 2.10. 1966 (NSW).

DISTRIBUTION: Known from the Wollombi Valley foothills, N.S.W., apparently extending south-west into the Wollemi Wilderness (Figure 24).

ECOLOGY: A component of dry sclerophyll forests on sandstone ridges.

While known only from a few stands, this taxon occurs in uniform stands with no apparent hybridism or intergradation with other species, in contrast to subsp. fergusonii. The ranges of the two subspecies do not overlap, and no intergradation appears to occur.

The epithet is from the Latin dorsum, 'back', and ventralis, 'pertaining to the belly', referring to the distinctly different surfaces of the hypostomatic adult leaves.

CONSERVATION STATUS: 2RC-. Most known populations of this subspecies occur within reserved lands.

\section{Eucalyptus placita L. Johnson \& K. Hill, sp. nov.}

$\mathrm{Ab}$ E. paniculata characteribus sequentibus differt: folia juvenilia adultaque nitide viridia, adulta amphistomatica; cortex mollis, suberosus; fructus breviusculus.

TYPE: New SOUTH WALES: North Coast: Manning Hill, on road from Upper Myall to Bunyah (32 $\left.{ }^{\circ} 15^{\prime} \mathrm{S} 152^{\circ} 11^{\prime} \mathrm{E}\right)$, L. Johnson 9014 \& C. Johnson, 21.4.1984 (holo NSW).

Tree to $25 \mathrm{~m}$ tall. Bark persistent, soft corky grey ironbark, pale brown under; smaller branches sometimes smooth, grey. Juvenile leaves disjunct, ovate to broadly elliptical, bright green, glossy, petiolate, strongly discolorous, to $10 \mathrm{~cm}$ long, $7 \mathrm{~cm}$ wide. Adult leaves disjunct, lanceolate to broad-lanceolate, acute or acuminate, glossy light green, distinctly discolorous (but amphistomatic), 7-15 cm long, 1.4-3.0 cm wide; petioles 12-20 mm long. Lateral veins well-spaced, regular, finely regularly reticulate between, at $30-50^{\circ}$ to midrib. Intramarginal vein distinct, \pm looped, 1-3 $\mathrm{mm}$ from margin. Inflorescences compound, comprising 7-flowered umbellasters aggregated on short lateral or terminal shoots; peduncles 5-11 long; pedicels $4-8 \mathrm{~mm}$ long. Buds broadly fusiform, 8-11 mm long, 4-5 mm diam. Calyptra double; outer shedding early; inner shorter and narrower than hypanthium with a distinct constriction at the junction, conical, acute. Stamens regularly inflexed, outer whorls longer and infertile; anthers adnate, cuboid, oblique, dehiscing through terminal pores. Fruit obconic, 6-9 $\mathrm{mm}$ long, 5-7 mm diam., 4-5-locular; stemonophore persistent; disc vertically depressed; valves deeply enclosed (Figure 25).

Distinguished from E. paniculata by the glossy light green amphistomatic adult leaves, the glossy light green juvenile leaves, the soft, corky bark, and the relatively short fruit.

This taxon is one of a number in the E. paniculata group that form a geographic 
replacement pattern along the coast of New South Wales. The taxa are for the most part allopatric, and intergradation is limited. E. fusiformis Boland \& Kleinig and E. ancophila L. Johnson \& K. Hill are broadly sympatric or parapatric with E. placita at the northern end of the range of the latter, although no intergradation is known.

Selected SPeCimens (from 19 examined): NeW South WALES: North Coast: $4.8 \mathrm{~km}$ from Dungay Road on Boonanghi Road, Boonanghi State Forest, K. Hill $776 \&$ \& L. Johnson, 6.5.1984 (CANB, NSW); Cobrabald Road, 4 km from 5-ways Hill, Bellangry State Forest, K. Hill 772 \& L. Johnson, 5.5.1984 (NSW); Bril Bril State Forest, NW of Wauchope, J.C. Cousins, 5.1957 (NSW); Gloucester Buckets, R. Covery, 8.9.1967 (NSW); Cranky Corner, 13 miles [22 km] SE of Singleton, R. Story $7389,10.5 .1960$ (NSW); 100 metres on Mt Bright road from Bellbird-Millfield road, K. Hill 750 \& L. Johnson, 2.5.1984 (NSW).

Distribution: North Coast of N.S.W., from the hinterland of the Kempsey district south to around Cessnock (Figure 26).

ECOLOGY: Locally frequent in sclerophyll forests on shallow soils on dry siliceous ridges of acid volcanics or sediments.

The epithet is from the Latin placitus, 'pleasing', from the appearance of the rather light green, glossy foliage.
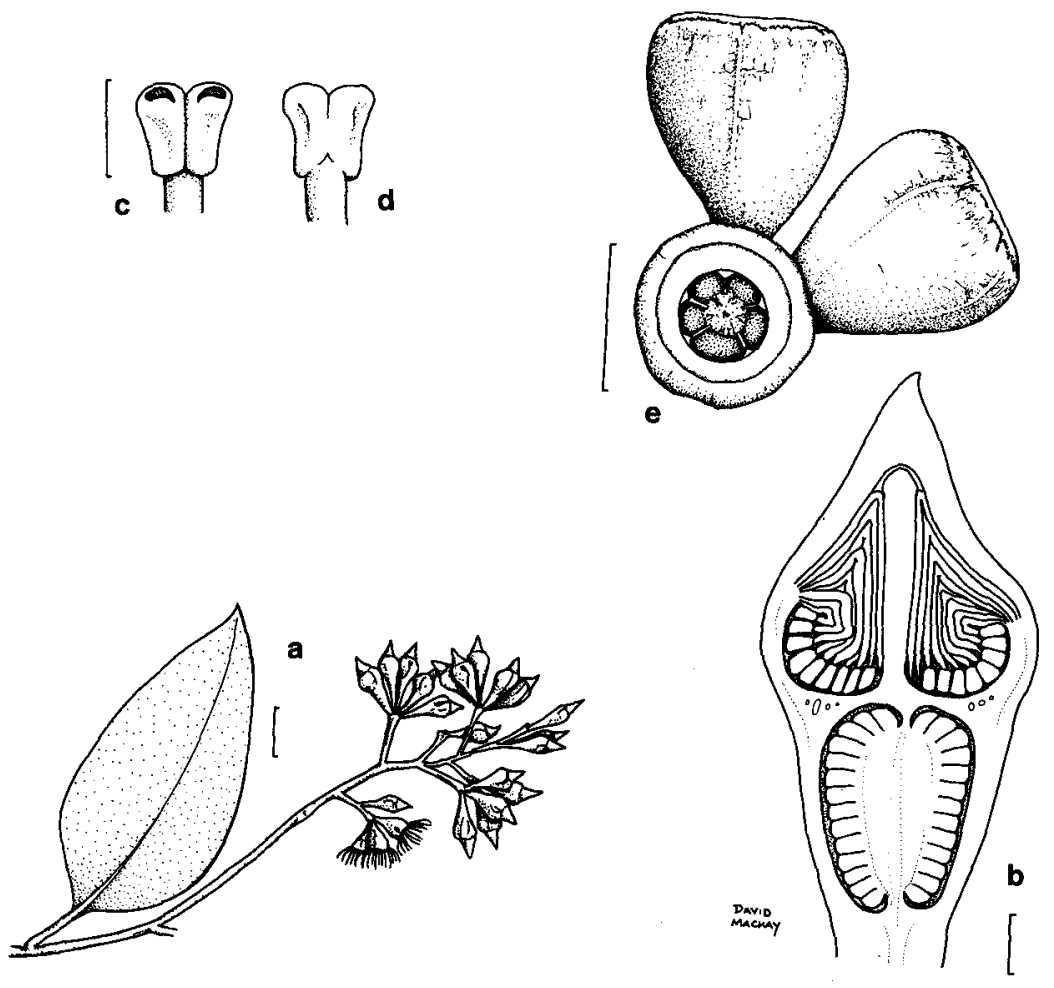

Figure 25. E. placita. a., adult leaf and flowers. b., median section of flower. c., d., anthers. e., fruit (from J.C. Cousins, 5.1957). Scale bar: $\mathrm{a}=1 \mathrm{~cm} ; \mathrm{b}=1 \mathrm{~mm} ; \mathrm{c}, \mathrm{d}=0.5 \mathrm{~mm} ; \mathrm{e}=5 \mathrm{~mm}$. 
CONSERVATION STATUS: Not considered to be at risk.

\section{Eucalyptus ancophila L. Johnson $\&$ K. Hill, sp. nov.}

$\mathrm{Ab}$ E. placita foliis adultis majoribus plus saturate viridibus et angustioribus, $\mathrm{ab} E$. fusiforme foliis adultis majoribus et fructibus brevioribus latioribusque, distinguitur.

TYPE: NEW SOUTH WALES: North Coast: 21 miles [33 km] NW of Kempsey, at western ridge of Mungay Creek, T.J. Evans NSW 222245, 2.1975 (holo NSW).

Tree to $35 \mathrm{~m}$ tall, sometimes taller. Bark persistent, dark grey ironbark, smaller branches sometimes smooth, grey. Juvenile leaves disjunct, petiolate, lanceolate to narrow-ovate, glossy, distinctly discolorous, to $8 \mathrm{~cm}$ long, $4 \mathrm{~cm}$ wide. Adult leaves disjunct, \pm lanceolate, acute or acuminate, \pm glossy green, slightly discolorous or concolorous, amphistomatic, 9-20 cm long, $1.8-4.5 \mathrm{~cm}$ wide; petioles $18-30 \mathrm{~mm}$ long; lateral veins well-spaced, regular, at $30-50^{\circ}$ to midrib, finely regularly reticulate between; intramarginal vein distinct, 1-2 mm from margin. Inflorescences compound, comprising 7-flowered umbellasters aggregated on short lateral or terminal shoots; peduncles 5-18 $\mathrm{mm}$ long; pedicels 4-6 mm long. Mature buds not seen. Calyptra double; outer shedding early; inner shorter and narrower than hypanthium with a distinct constriction at the junction, conical, acute. Stamens regularly inflexed, outer whorls longer and infertile; anthers adnate, cuboid, oblique, dehiscing through terminal pores. Fruit broadly obconic or ovoid, 6-8 mm long, 5-7 mm diam.; 4-locular (rarely 3); stemonophore persistent; disc vertically depressed; valves deeply enclosed.

Distinguished from E. placita by the lanceolate, darker green and longer adult leaves with longer petioles, and the lanceolate to narrow-ovate juvenile leaves. Distinguished from $E$. fusiformis by the larger and more shining green adult leaves (to $15 \mathrm{~cm}$ long in $E$. fusiformis) and the shorter and broader fruit (5-9 $\mathrm{mm}$ long, 4-5 $\mathrm{mm}$ diam. in $E$. fusiformis).

Selected SPECimens (from 7 examined): New South Wales: North Coast: Bellingen Heights, E.H.F. Swain, 3.1910 (NSW); $3.6 \mathrm{~km}$ from W end of Allgomera Creek Road, Ingalba State Forest, K. Hill $785 \&$ L. Johnson, 6.5.1984 (NSW); 'Anzac Valley', upper Mungay Creek, L. Johnson 8710 28.1.1983 (NSW); Dennis Creek, $6 \mathrm{~km}$ direct NNE of Willawarrin, L. Johnson 8708, 28.1.1983 (NSW).

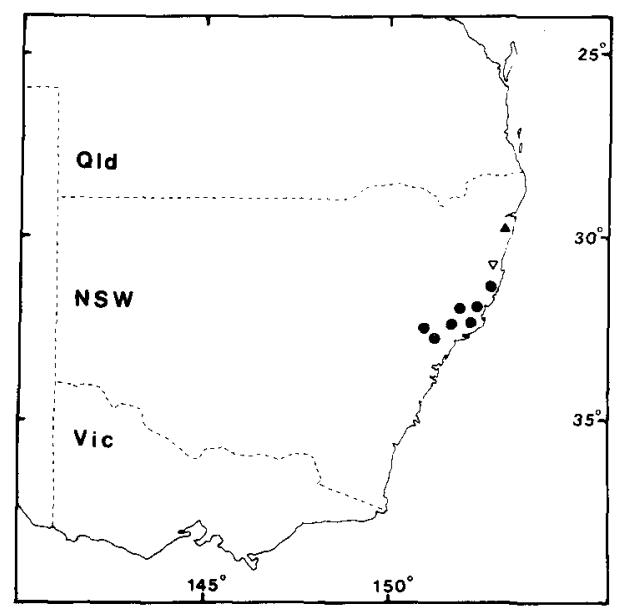

Figure 26. Distribution of E. tetrapleura (solid triangle), E. fusiformis (open triangle) and E. placita (circle). 
DISTRIBUTION: Known only from the Kempsey-Bellingen district of coastal N.S.W. (Figure 19).

ECOLOGY: Usually along creeks or valley bottoms in moderately dissected coastal range country, in tall forest with a dense rainforest understorey. This habitat differs from those of both E. placita and E. fusiformis, which are species of drier forests along ridges.

The epithet is from the Latinised Greek ancos, 'a valley', philus, 'loving', from the habitat.

CONSERVATION STATUS: 2R. Significant populations of this species occur within State Forests, although overall distribution is still poorly known.

\section{Eucalyptus beyeriana $L$. Johnson \& $K$. Hill, sp. nov.}

Inter species $E$. paniculatae affines foliis adultis juvenilibusque angustis non lucentibus et fructibus parvis distinguitur.

TYPE: NeW SOUTH WALES: Central Coast: Nortons Basin, about $2.5 \mathrm{~km}$ NW of Wallacia, T. James 898, W. Bishop \& C. Dunn, 2.9.1987 (holo NSW; iso CANB).

This name is provided for the taxon previously known as E. beyeri $R$. Baker, which was based on E. paniculata Sm. var. angustifolia Benth. The type citation for the latter is 'N.S.Wales, "Narrow-leaved Iron-bark", Woolls'. An isotype in NSW from the Woolls herbarium bears the locality 'Moolah', which cannot now be identified. This specimen has anthers intermediate in morphology between those of $E$. beyeriana and $E$. crebra $\mathrm{F}$. Muell. These taxa are often sympatric or closely parapatric, and hybrid individuals occur frequently, although no evidence exists for complex hybrids beyond the F1 generation. Since the type is thus apparently from a plant of hybrid origin, the name $E$. beyeri can no longer be applied in its widely-used sense, and a new name is required. The name $E$. beyeriana is chosen because it is sufficiently similar to the old name to minimise the effect of the change.

= E. panda S.T. Blake subsp. illaquens L. Johnson, Contrib. New South Wales Natl Herb. 3(3): 120 (1962).

TyPe CitAtion: 'Holotype: 2 miles [3.2 km] E of Munghorn (Cooyal to Wollar), N.S.W., C.K. Ingram 22.11.1952 (NSW 54103), flowering and fruiting.'

This name was applied to somewhat more glaucous populations from the Central and North Western Slopes of N.S.W. Further field study has shown the distribution of these and the coastal populations formerly known as $E$. beyeri to be much more continuous than previously thought, and we now regard the western populations as belonging to E. beyeriana.

Tree to $25 \mathrm{~m}$ tall. Bark persistent, dark grey ironbark, smaller branches sometimes smooth, grey. Juvenile leaves disjunct, petiolate, lanceolate to narrow-lanceolate, dull, slightly discolorous, to $7 \mathrm{~cm}$ long, $1.5 \mathrm{~cm}$ wide. Adult leaves disjunct, narrow-lanceolate to lanceolate, acute or acuminate, dull green or grey-green, slightly discolorous or concolorous, amphistomatic, 6-12 cm long, 0.7-2.0 cm wide; petioles 10-20 mm long; lateral veins well-spaced, regular, at $40-50^{\circ}$ to midrib, finely regularly reticulate between; intramarginal vein distinct, c. $1 \mathrm{~mm}$ from margin. Inflorescences compound, comprising 7-flowered umbellasters aggregated on short lateral or terminal shoots; peduncles 5-10 long; pedicels 4-8 mm long. Mature buds clavate, 3-5 mm long, 2-3 $\mathrm{mm}$ wide. Calyptra double; outer shedding early; inner shorter and narrower than hypanthium, hemispherical or broadly conical. Stamens regularly inflexed, outer whorls longer and infertile; anthers adnate, cuboid, oblique, dehiscing through terminal pores. Fruit broadly obconic or ovoid, 4-6 mm long, 3-6 mm diam.; stemonophore persistent; disc vertically depressed; valves deeply enclosed. 
E. beyeriana is distinguished within the E. paniculata group by the narrow, dull adult and juvenile leaves and the small fruit.

The epithet recalls the fact that this species has been generally but mistakenly known as E. beyeri R. Baker, and in turn commemorates George Beyer (1865-1920) of the former Sydney Technological Museum, who assisted R.T. Baker.

\section{Eucalyptus apothalassica L. Johnson \& K. Hill, sp. nov.}

$\mathrm{Ab}$ E. umbra distinguitur: fructus parvi apice contracti, folia adulta parva plus concolores et amphistomatica, folia juvenilia disjuncta et caerulescentia.

TYPE: QUeENSLAND: on property $5 \mathrm{~km} \mathrm{~S}$ of Kogan on Tara Road $\left(27^{\circ} 04^{\prime} \mathrm{S} 150^{\circ} 03^{\prime} \mathrm{E}\right), \mathrm{K}$. Hill 1245 \& L. Johnson, 25.8.1984 (holo NSW; iso PERTH, BRI, CANB).

Tree to $15 \mathrm{~m}$ tall. Bark fully persistent, thin, long-fibrous. Juvenile leaves opposite, quickly becoming disjunct, broad-lanceolate to ovate, falcate, to $15 \mathrm{~cm}$ long, $5 \mathrm{~cm}$ wide. Adult leaves disjunct, lanceolate, glossy green, concolorous or very slightly discolorous, amphistomatic, 6-12 cm long, 1.2-2.6 cm wide; petioles flattened, 8-22 $\mathrm{mm}$ long; lateral veins regular, moderately spaced, at $30-45^{\circ}$ to midrib, regularly reticulate between; intramarginal vein distinct, 1-2 $\mathrm{mm}$ from margin. Inflorescences axillary, often aggregated on short shoots to appear compound, umbellasters 11- or more flowered; peduncles terete, 8-14 mm long; pedicels 2-6 mm long. Buds ovoid to broadly fusiform (fully mature buds not seen). Calyptra appearing single, conical, acute to rostrate, as long as hypanthium. Stamens irregularly flexed, all fertile. Fruit globulartruncate, apically contracted, 4-locular, 5-7 mm long, 5-7 mm diam.; disc narrow (c. $0.5 \mathrm{~mm}$ wide), sunken, often obscured by incurved hypanthium; valves narrow, acute, sharply raised, the tips rim level or exserted. Seeds brown.

Distinguished from E. umbra R. Baker by the small, apically contracted fruit (6-8 $\mathrm{mm}$ long, 7-9 mm diam. in E. umbra), the small, more concolorous adult leaves $(10-14 \mathrm{~cm}$ long, $2.5-3.5 \mathrm{~cm}$ wide in $E$. umbra), and the disjunct, bluish juvenile leaves. Fruit and bark resemble those of $E$. acmenoides Schauer, which is distinguished by the hypostomatic and very strongly discolorous adult leaves.

SeleCted SPECIMENS (from 14 examined): QueENSLAND: Boolimbah Bluff, Carnarvon Gorge, K. Hill

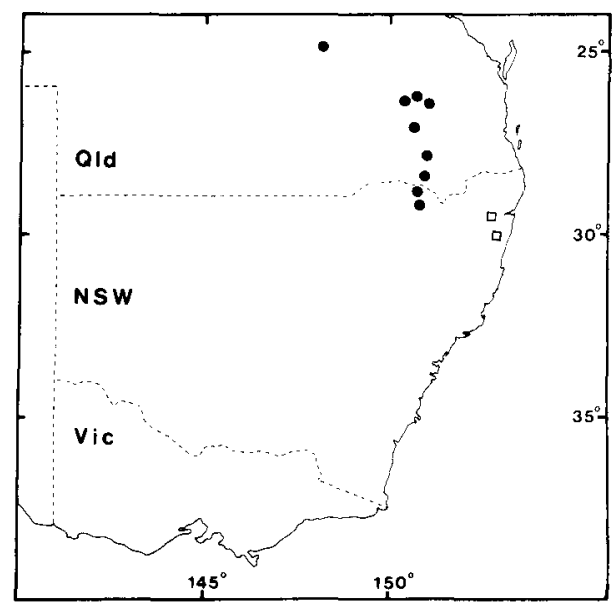

Figure 27. Distribution of E. apothalassica (circle) and E. psammitica (open square). 
1330, 1.1.1986 (NSW); Mudwall block, Barakula State Forest, M.I.H. Brooker 4785, 17.4.1975 (CANB, NSW); Nudley forest reserve, $32 \mathrm{~km} \mathrm{~N}$ of Jandowae, L. Johnson, 5.6.1959 (NSW); Inglewood State Forest $\left(28^{\circ} 24^{\prime} \mathrm{S} 151^{\circ} 02^{\prime} \mathrm{E}\right), \mathrm{K}$. Hill 808 \& L. Johnson, 9.5.1984 (NSW). NEW SouTH WALES: North Western Slopes: Bruxner Highway, near Bebo State Forest, J. Benson, 5.1986 (NSW).

Distribution: A scattered and nowhere abundant species, extending from the Carnarvon Range in central Qld to the far North Western Slopes in N.S.W., north-east of Warialda (Figure 27).

ECOLOGY: A minor component of dry sclerophyll woodlands on sand accumulations or on shallow sand on sandstone. Associated species include Callitris glaucophylla J. Thompson \& L. Johnson and Eucalyptus chloroclada (Blakely) L. Johnson \& K. Hill.

The epithet is from the Greek apo, 'away from', and thalassos, 'the sea', from the distribution away from the coast (an unusual distribution within the white mahogany group).

CONSERVATION STATUS: Not considered to be at risk.

\section{Eucalyptus psammitica $L$. Johnson \& $K$. Hill, sp. nov.}

$\mathrm{Ab} E$. acmenoide characteribus sequentibus differt: folia juvenilia latiora; folia adulta concoloria amphistomaticaque; fructus major. $\mathrm{Ab} E$. umbra differt: folia juvenilia angustiora; discus fructus latus planusque eo E. carneae similis.

TYPE: New South Wales: North Coast: $3.2 \mathrm{~km} \mathrm{~N}$ of Coaldale on Grafton road, $R$. Coveny 4985, 23.8.1973 (holo NSW).

Tree to $15 \mathrm{~m}$ tall. Bark fully persistent, thin, long-fibrous. Juvenile leaves opposite, sessile, broad-lanceolate to ovate, green, discolorous, to $15 \mathrm{~cm}$ long, $5 \mathrm{~cm}$ wide. Adult leaves disjunct, lanceolate, glossy green, concolorous or very slightly discolorous, 8-18 $\mathrm{cm}$ long, $1.5-3.0 \mathrm{~cm}$ wide; petioles flattened, $12-20 \mathrm{~mm}$ long; lateral veins regular, moderately spaced, at $30-45^{\circ}$ to midrib, regularly reticulate between; intramarginal vein distinct, 1-3 mm from margin. Inflorescences axillary, umbellasters 7-11-flowered; peduncles angular, $12-18 \mathrm{~mm}$ long; pedicels 3-6 mm long. Buds ovoid to broadly fusiform (fully mature buds not seen). Calyptra appearing single, conical, rostrate, as long as hypanthium. Stamens irregularly flexed, all fertile. Fruit globular-truncate, 4locular, 8-10 mm long, 7-9 mm diam.; disc distinct, flat, c. $1 \mathrm{~mm}$ wide; valves broadly triangular, retracting laterally, tips remaining flat and enclosed. Seeds brown.

Distinguished from E. acmenoides Schauer by the broad-lanceolate juvenile leaves, the large fruit (to $7 \times 7 \mathrm{~mm}$ in $E$. acmenoides), and the almost concolorous adult leaves. The narrower juvenile leaves and the broad, flat disc separate this taxon from $E$. umbra $R$. Baker (which has ovate juvenile leaves and a narrow, depressed disc). The fruit are most like those of $E$. carnea R. Baker, which is distinguished by its disjunct juvenile leaves.

Selected SPecimens (from 5 examined): New South Wales: North Coast: $0.9 \mathrm{~km}$ from the Grafton-Coaldale road on Stockyard Creek road, K. Hill 2754, L. Johnson \& P. Weston, 19.10.1987 (MEL, NSW, PERTH, CBG), K. Hill 793 \& L. Johnson, 7.5.1984 (NSW); $1.3 \mathrm{~km} \mathrm{~N}$ of Kremnos Creek, N of Glenreagh, K. Hill 2741, L. Johnson \& P. Weston, 18.10.1987 (NSW).

DISTRIBUTION: Restricted to a belt of sandstone country running from north-west of Coffs Harbour to north-west of Grafton, N.S.W. (Figure 27).

ECOLOGY: Locally frequent in dry sclerophyll woodland on shallow sand on sandstone, often in association with E. baileyana F. Muell., E. planchoniana F. Muell. and Angophora robur L. Johnson \& K. Hill.

The epithet is from the Greek psammites, 'sand', from the occurrence on sandy soils over sandstone. 
CONSERVATION STATUS: $3 \mathrm{~V}$-. The poor sandstone outcrop habitat of this species would not be under immediate direct threat from pastoral activity. More field study is, however, required to evaluate the distribution and abundance of this taxon.

\section{Eucalyptus stannicola L. Johnson \& K. Hill, sp. nov.}

$\mathrm{Ab}$ E. youmanii characteribus sequentibus differt: folia alabastraque plus minusve glauca (sed haud pruinosa); pedunculi pedicellique longiores; alabastra minus angulata.

TYPE: NEW SOUTH WALES: North Western Slopes: 4.3 miles [6.8 km] S of Inverell, R.D. Johnston \& G.M. Chippendale 648, 14.6 .1968 (holo NSW; iso CANB).

Tree to $12 \mathrm{~m}$ high, often of irregular habit. Bark persistent throughout, long-fibrous, grey-brown ('stringybark'). Seedling leaves opposite for few nodes, variably lanceolate to ovate, a few sessile, hispid with hair tufts on emergent oil glands. Juvenile leaves disjunct, glabrous, ovate, to $12 \mathrm{~cm}$ long, $7 \mathrm{~cm}$ wide; petioles to $1.1 \mathrm{~cm}$ long. Adult leaves disjunct, similifacial, lanceolate, falcate, oblique, often slightly dull and somewhat bluish, 7-16 cm long, $1.3-3.2 \mathrm{~cm}$ wide; petioles to $1.9 \mathrm{~cm}$ long; lateral veins moderately spaced, regular, at $25-40^{\circ}$ to midrib; reticulum even; oil glands large, sparse; intramarginal vein continuous, distinct, $0.5-2.0 \mathrm{~mm}$ from margin. Inflorescences simple, axillary; umbellasters 7-flowered; peduncles flattened, $8-23 \mathrm{~mm}$ long, to $3 \mathrm{~mm}$ wide apically; pedicels angular, 1-5 mm long. Mature buds clavate to ovoid, angular, bluish, 5-7 mm long, 3-5 mm diam. Calyptra appearing single, hemispherical to conical, convex, acute or apiculate, about as long as hypanthium. Fruit hemispherical or globular, 3-locular, 8-12 mm long, 9-13 mm diam.; calyptra scar forming a concave band around fruit, $0.5-2.5 \mathrm{~mm}$ wide; stemonophore vertically raised, less than $0.5 \mathrm{~mm}$ wide; disc raised at $45-90^{\circ}$, ultimately flattened, $2.5-4.0 \mathrm{~mm}$ wide; valves broadly triangular, acute, basally enclosed, apically rim level to strongly exserted, raised at $45-90^{\circ}$. Seeds glossy, dark brown, angular, pyramidal, dorsally rounded, regularly very shallowly reticulate; hilum terminal; chaff pale brown.

E. stannicola differs from other species of the E. youmanii Blakely \& McKie group in the more or less bluish leaves and buds, the longer peduncles and pedicels and the less angular buds. The buds and fruit are generally smaller, and the leaves narrower.

E. stannicola forms consistent populations, with some intergradation with $E$. macrorhyncha F. Muell. ex Benth. in the south of the range.

Selected SPECiMENS (from 20 examined): NeW SOUTH WALES: Northern Tablelands: Torrington, R.H. Cambage 1824, 30.9.1907 (NSW); 'Kelso', Kangaroo camp, E.N. McKie \& T. Youman, 1.11.1929 (NSW); Longford to Bendemeer, R.W. Jessup \& A. Gray 3336, 9.10.1951 (NSW). North Western Slopes: 20.3 miles [30.5 km] from Inverell towards Yetman, M.I.H. Brooker 3937, 28.2.1973 (CANB, NSW); $5.5 \mathrm{~km} \mathrm{~S}$ of Inverell on Tingha road, P.H. Weston 1096, K. Hill \& L. Johnson, 20.10.1987 (NSW, PERTH, CANB, BRI); Tingha, R.H. Cambage 962, 14.10.1903 (NSW).

Distribution: New SOUTH WALES: Western Northern Tablelands and eastern North Western Slopes, from Torrington to south of Tingha (Figure 28).

ECOLOGY: A locally dominant species on shallow coarsely sandy soils over the tinbearing acid granites of this area, often in association with $E$. andrewsii Maiden and $E$. prava L. Johnson \& K. Hill.

The epithet is from the Latin stannum, 'tin', -cola, 'an inhabitant', from the occurrence on 'tin granites'. The epithet is a noun in apposition, and its ending is not subject to change according to gender of the associated generic name.

CONSERVATION STATUS: Not considered to be at risk. 


\section{Eucalyptus williamsiana $L$. Johnson \& $K$. Hill, sp. nov.}

$\mathrm{Ab}$ E. youmanii characteribus sequentibus differt: folia intermedia majora et orbicularia; folia adulta saepissime majora; alabastra fructusque majores.

TYPE: NeW SOUTH WALES: Northern Tablelands: $1.5 \mathrm{~km}$ E of $W$ boundary of Gibraltar Range National Park on highway, K. Hill 1278, L. Johnson \& J. Williams, 10.9.1985 (holo NSW; iso CANB, BRI).

Tree to $20 \mathrm{~m}$ high, often less, usually dense-crowned. Juvenile leaves disjunct, ovate to orbicular, $15 \mathrm{~cm}$ long, to $13 \mathrm{~cm}$ wide; hispid with hair tufts on emergent oil glands, becoming glabrous; petioles to $1.3 \mathrm{~cm}$ long. Adult leaves disjunct, similifacial, broad lanceolate, oblique, acute or acuminate, glossy dark green, $8-18 \mathrm{~cm}$ long, $1.6-5.0 \mathrm{~cm}$ wide; petioles to $2.3 \mathrm{~cm}$ long, thick, flattened or quadrangular; lateral veins moderately to widely spaced, regular, at c. $30^{\circ}$ to midrib; reticulum incomplete; oil glands large, moderately densely spaced; intramarginal vein continuous, distinct, $1.5-4.0 \mathrm{~mm}$ from margin. Inflorescences simple, axillary; umbellasters 7-11-flowered; peduncles thick, angular, 3-12 $\mathrm{mm}$ long; pedicels thick, angular, 0-2 mm long. Mature buds angular, ovoid, 9-12 $\mathrm{mm}$ long, 6-7 $\mathrm{mm}$ diam. Calyptra appearing single, conical, convex, broadly apiculate, about as long as hypanthium. Fruit sessile, cup-shaped, 3-4-locular, 9-13 mm long, 10-15 mm diam.; calyptra scar vertically raised, forming a concave band around the fruit, $0.5-1.0 \mathrm{~mm}$ wide; stemonophore vertically raised, $0.2-0.5 \mathrm{~mm}$ wide; disc vertically raised, ultimately flattened, 3-5 $\mathrm{mm}$ wide; valves broadly triangular, obtuse, basally deeply enclosed, apically enclosed or rim level, raised at c. $45^{\circ}$. Seeds glossy, dark brown, angular, pyramidal, dorsally rounded, regularly shallowly reticulate; hilum terminal; chaff pale orange brown (Figure 29).

E. williamsiana differs from E. youmanii in the larger, orbicular intermediate leaves and generally larger adult leaves and the larger buds and fruit.

SELECTED SPECIMENS (from 24 examined): QUEENSLAND: c. $6 \mathrm{~km}$ NNE of Wallangarra, $1.8 \mathrm{~km}$ SSE of Mt Norman, M.D. Crisp 7326, 7327 \& I.R. Telford, 28.9.1984 (AD, CBG, MEL, NSW); turnoff to Mt Norman, Girraween National Park, N. Byrnes 4093, 31.8.1982 (NSW, BRI, CANB). New SouTH WALES: Northern Tablelands: Forestland State Forest, c. 15 miles [24 km] SSE of Tenterfield, R.J. Turner NSW 30889, 16.2.1955 (NSW); Chaelundi Mountain, hill on E side of road, K. Hill 2736, L. Johnson \& P. Weston, 18.10 .1987 (NSW); $4.6 \mathrm{~km} \mathrm{~W}$ of Armidale turnoff on Ebor-Guyra road, J.D.

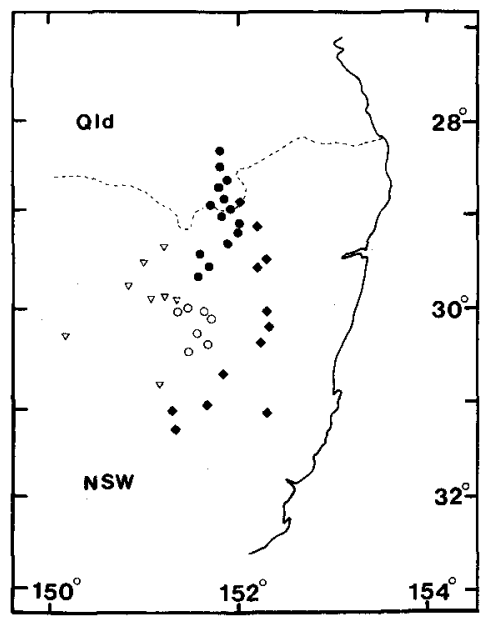

Figure 28. Distribution of E. williamsiana (diamond), E. subtilior (solid circle), E. stannicola (open triangle) and E. youmanii (open circle). 
Briggs 11, 1.8.1977 (CANB, NSW); near Apsley Falls, E.C. Andrews per R.H. Cambage 1217, 5.1905 (NSW); Spokes Hill area, Mt Boss State Forest, M.G. White, 4.9.1957 (NSW); Campfire, via Niangala, B. Small, 10.1960 (NSW).

DISTRIBUTION: Sporadic, from the Wallangarra district in Queensland through the eastern ranges of the Northern Tablelands of N.S.W, from the Queensland border to the Niangala-Yarrowitch district (Figure 28).

ECOLOGY: Locally abundant in dry sclerophyll forests or woodlands, usually but not always on sandy soils over acid granite on the wetter range country of the eastern tablelands. Often associated with E. campanulata R. Baker \& H.G. Smith, although on locally poorer sites.

The specific epithet honours John Beaumont Williams of the Botany Department of the University of New England, Armidale, whose comprehensive knowledge of the flora of the New England region has been of immense benefit to many visiting botanists, and

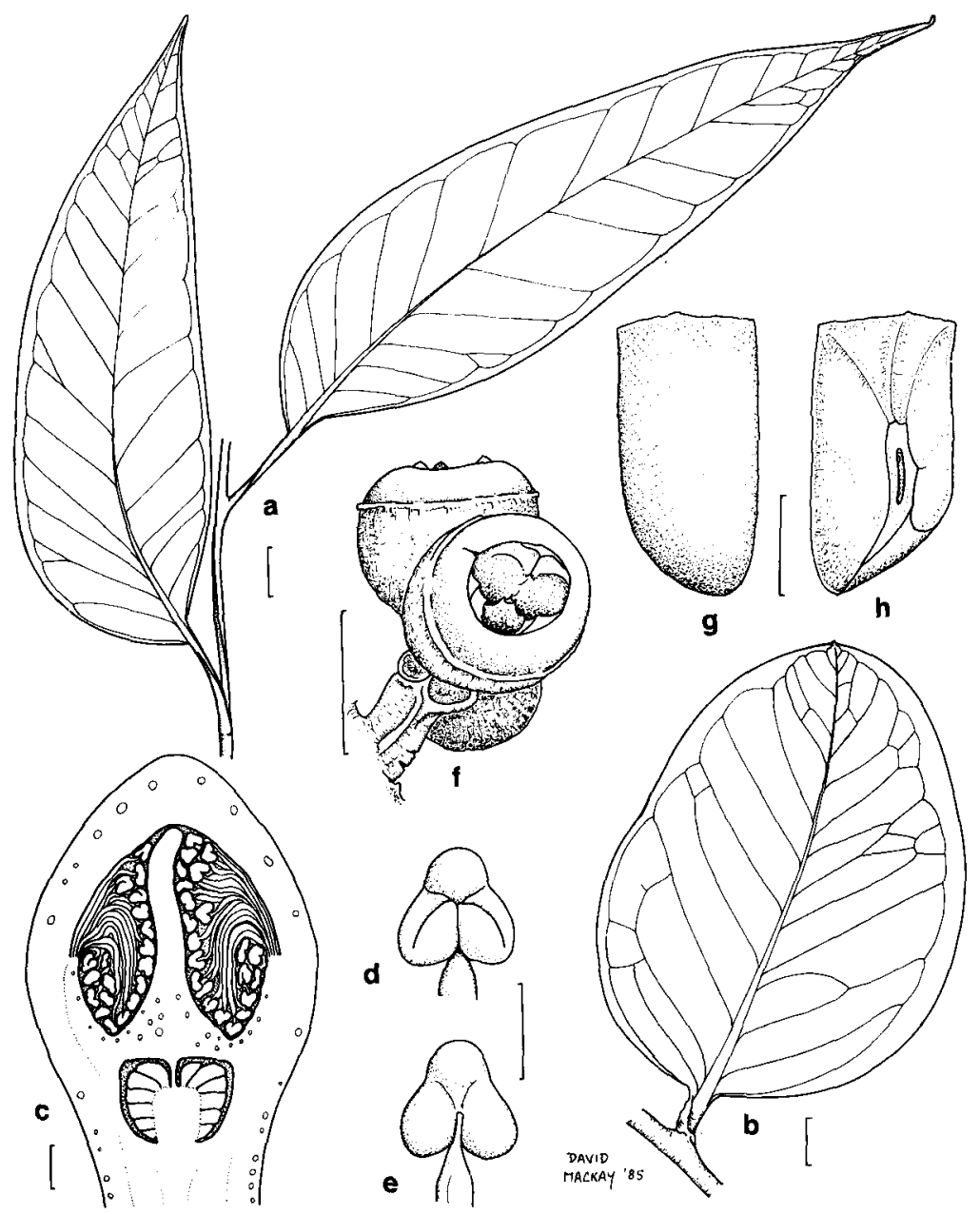

Figure 29. E. williamsiana. a., adult leaves. b., juvenile leaf. c., median section of bud. d., e., anthers. f., fruit. g., h., seeds (all from R.J. Turner NSW 30889 ). Scale bar: $a, b, f=1 \mathrm{~cm} ; c, g, h=$ $1 \mathrm{~mm} ; \mathrm{d}_{e} \mathrm{e}=0.5 \mathrm{~mm}$. 
who has contributed to understanding of perianth structure in the bloodwood group of eucalypts.

CONSERVATION STATUS: Not considered to be at risk.

\section{Eucalyptus subtilior L. Johnson \& K. Hill, sp. nov.}

$\mathrm{Ab}$ E. youmanii et E. williamsiana characteribus sequentibus differt: alabastra fructusque minores; folia juvenilia adultaque angustiora.

TYPE: QueENSLAND: Ballandean, S.T. Blake 20400, 15.7.1958 (holo NSW; iso BRI, CANB, $\mathrm{K}, \mathrm{MO}, \mathrm{SP})$.

Tree to $15 \mathrm{~m}$ high, often less, usually of irregular habit. Bark persistent throughout, long-fibrous, grey-brown ('stringybark'). Seedling leaves opposite for the first few nodes, broad-lanceolate, initially sessile, hispid with hair tufts on emergent oil glands. Juvenile leaves disjunct, broad-lanceolate, strongly oblique, glabrous, to $12 \mathrm{~cm}$ long, $4 \mathrm{~cm}$ wide;

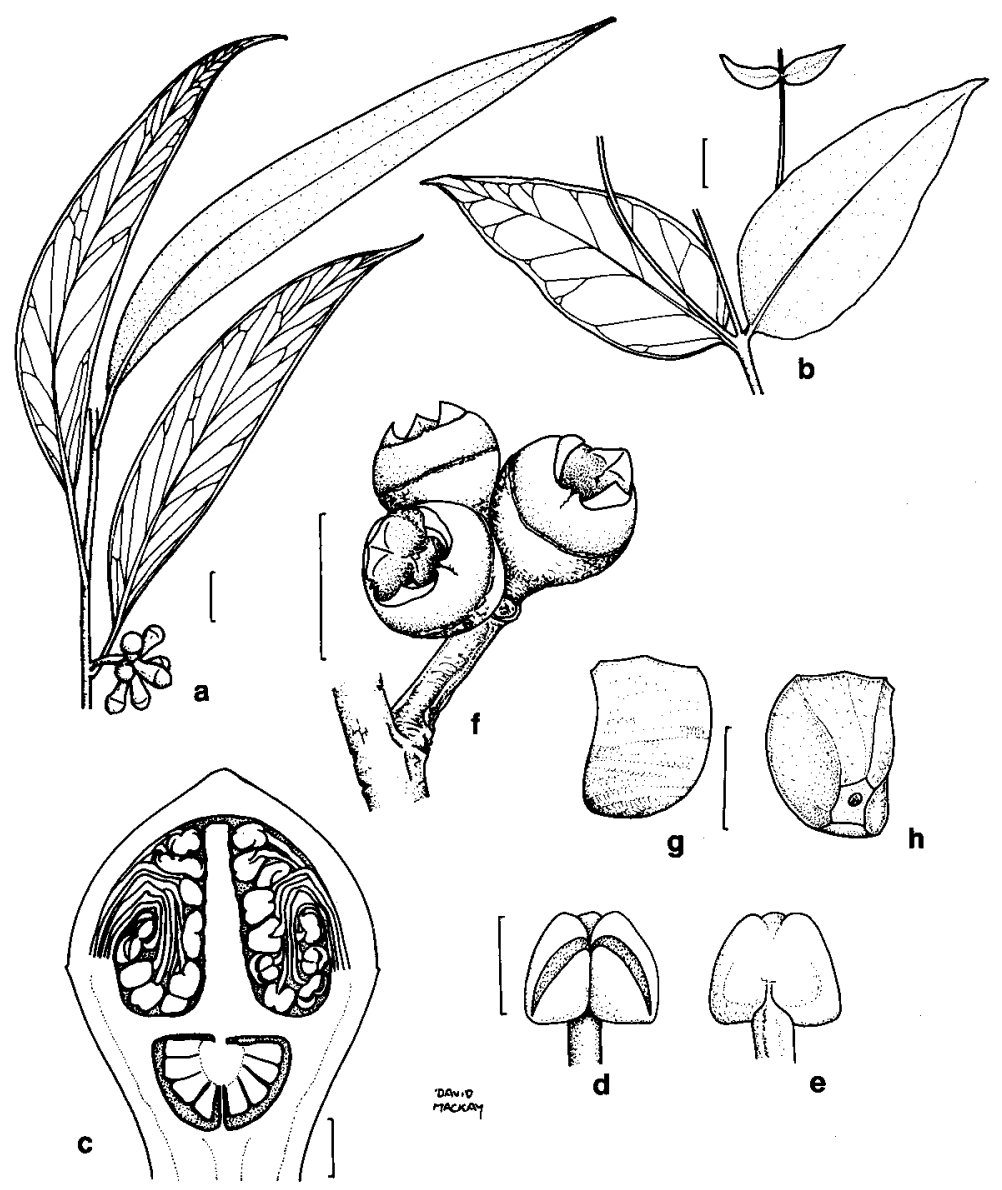

Figure 30. E. subtilior. a.A, adult leaves with buds. b., juvenile leaves. c., median section of bud. d., e., anthers. f., fruit. g., h., seeds (all from J.L. Boorman, 1.1918 except b, from J.H. Simmonds, 27.10.1910). Scale bar: $a, b, f=1 \mathrm{~cm} ; c, g, h=1 \mathrm{~mm}$;,$e=0.5 \mathrm{~mm}$. 
petioles to $1.2 \mathrm{~cm}$ long. Adult leaves disjunct, similifacial, lanceolate to broadlanceolate, falcate, oblique, sometimes slightly bluish, 6-16 cm long, $1.1-2.3 \mathrm{~cm}$ wide; petioles to $1.6 \mathrm{~cm}$ long, quadrangular; lateral veins moderately spaced, regular, at $20-30^{\circ}$ to midrib; reticulum even; oil glands large, moderately spaced; intramarginal vein continuous, distinct, $0.5-2.0 \mathrm{~mm}$ from margin. Inflorescences simple, axillary; umbellasters 7-flowered; peduncles flattened, $4-11 \mathrm{~mm}$ long, to $0.25 \mathrm{~cm}$ wide; pedicels markedly angular, 0-2 mm long. Mature buds ovoid to clavate, 3-4-angled, usually dull and slightly bluish, 7-8 $\mathrm{mm}$ long, 3-4 $\mathrm{mm}$ diam. Calyptra appearing single, hemispherical or conical, convex, obtuse, slightly shorter than hypanthium. Fruit sessile, \pm angular, cup-shaped or globular, 6-10 mm long, 7-12 mm diam.; calyptra scar and stemonophore raised, forming a concave band around the fruit; disc raised, ultimately flattened; valves broadly triangular, acute or obtuse, basally enclosed, apically exserted. Seeds glossy dark brown, angular, pyramidal or reniform, dorsally rounded; hilum ventral; chaff pale brown (Figure 30 ).

E. subtilior differs from E. williamsiana and E. youmanii in the smaller, often dull bluish buds, the smaller fruits, and the narrower juvenile and adult leaves.

SELECTED SPECIMENS (from 29 examined): QuEENSLAND: $\mathrm{N}$ of Dalveen, S.T. Blake 20411, 16.7.1958 (BRI, NSW); 17 km WSW of Stanthorpe, L. Pedley A7422, 27.3.1974 (CANB, NSW); Stanthorpe, J.L. Boorman, 1.1918 (NSW), J.H. Simmonds, 27.10.1910 (NSW); Wallangarra, S.T. Blake 20395, 14.7.1958 (BRI, CANB, MO, NSW). NEW SOUTH WALES: Northern Tablelands: Stoney Creek, c. 2 $\mathrm{km}$ S of Tenterfield, D.F. Blaxell 1842, 25.3.1981 (NSW); Sawyers Gully Road, W of Tenterfield, M.I.H. Brooker 7282, 3.3.1982 (CANB, NSW); 0.5 mile [0.8 km] N of Beardy Waters, $\mathrm{N}$ of Glen Innes, L.A.S. Johnson \& H.S. McKern, 24.5.1957 (NSW); road to Rangers Valley, c. 10 miles [16 km] directly $\mathrm{N}$ of Glen Innes, L.A.S. Johnson \& D.J. McGillivray 2434, 21.9.1966 (NSW).

DISTRIBUTION: Granite Belt district of Queensland, from Wallangarra to Stanthorpe, south through the central Northern Tablelands of N.S.W., from Wallangarra to near Glen Innes (Figure 28).

ECOLOGY: Locally abundant in dry sclerophyll woodlands, usually on sandy soils over granite, mostly on less infertile granites than $E$. williamsiana.

The epithet is from the Latin subtilior, 'more slender or delicate' (by comparison with $E$. youmanii and E. williamsiana).

CONSERVATION STATUS: Not considered to be at risk.

35. Eucalyptus youmanii Blakely \& McKie, Proc. Linn. Soc. New South Wales 55: 590 (1930).

TYPE CITATION: 'Specimens from Rosehill, 61/2 miles [10.4 km] SW. of Guyra (T. Youman, Rev. E.N. McKie, and W.F. Blakely, October, 1929) constitute the type'.

TYPE: holo NSW; iso K. Although cited as 'specimens', this collection comprises several pieces with one label in a single folder, and is hence accepted as a single collection.

Tree to $20 \mathrm{~m}$ high, usually dense-crowned. Juvenile leaves disjunct, broad-lanceolate to ovate, to $8 \mathrm{~cm}$ long, to $4.5 \mathrm{~cm}$ wide; hispid with hair tufts on emergent oil glands, becoming glabrous; petioles to $1.0 \mathrm{~cm}$ long. Adult leaves disjunct, similifacial, broad lanceolate, oblique, acute or acuminate, glossy dark green, 9-14 cm long, 1.6-3.5 cm wide; petioles to $2.0 \mathrm{~cm}$ long, thick, flattened or quadrangular; lateral veins moderately to widely spaced, regular, at c. $30^{\circ}$ to midrib; reticulum incomplete; oil glands large, moderately densely spaced; intramarginal vein continuous, distinct, 1-2 $\mathrm{mm}$ from margin. Inflorescences simple, axillary; umbellasters 7-flowered; peduncles thick, angular, 8-15 mm long; pedicels thick, angular, 0-2 $\mathrm{mm}$ long. Mature buds angular, ovoid or fusiform, glossy, 8-10 $\mathrm{mm}$ long, 5-7 $\mathrm{mm}$ diam. Calyptra appearing single, conical, 
convex, often angular, sometimes broadly apiculate, about as long as hypanthium. Fruit sessile, cup-shaped, 3-4-locular, 9-12 mm long, 8-15 mm diam.; calyptra scar raised at $45^{\circ}-90^{\circ}$, forming a concave band around the fruit, $0.5-1.0 \mathrm{~mm}$ wide; stemonophore raised, to $0.5 \mathrm{~mm}$ wide; disc raised at $45^{\circ}-90^{\circ}$, ultimately flattened, $2-4 \mathrm{~mm}$ wide; valves broadly triangular, obtuse, basally deeply enclosed, apically enclosed or rim level, raised at c. $45^{\circ}$. Seeds glossy, dark brown, angular, pyramidal, dorsally rounded, regularly shallowly reticulate; hilum terminal; chaff pale orange brown.

The removal of the above three species from E. youmanii substantially alters the circumscription of the latter. The notes on distribution and ecology together with the specimens cited here are intended to clarify the new, narrower circumscription of $E$. youmanii.

E. youmanii as defined here is distinguished by ovate to broad-lanceolate juvenile and intermediate leaves, glossy buds and sessile fruit. It is in general coarser than $E$. subtilior, less coarse than E. williamsiana, and disjunct from both.

Intergrading populations occur with E. laevopinea R. Baker, and hybrids are known with E. stellulata Sieber ex DC.

SELECTED SPECIMENS (from 19 examined): NEW SOuTH WALES: Northern Tablelands: 17.4 miles $[27.8 \mathrm{~km}]$ from Guyra towards Tingha, M.I.H. Brooker 3928, 27.2.1973 (CANB, NSW); Hartmann's paddock, near S.F. 322, Llangothlin, E.N. McKie 152, 20.4.1928 (NSW); c. 7.5 miles [12 km] SW of Guyra, E.N. McKie 146, 7.6.1928 (NSW); $1.9 \mathrm{~km}$ E of New England Highway on Sunnyside road, turnoff $11 \mathrm{~km} \mathrm{~N}$ of Armidale, M.I.H. Brooker 7260, 2.3.1982 (CANB, NSW); Tea Tree Creek, c. $19 \mathrm{~km} \mathrm{~W}$ of Armidale on Bundarra road, K. Hill 1306 \& L. Johnson, 12.9.1985 (BRI, CANB, NSW).

DisTRIBUTION: A restricted species, occupying a belt from Wandsworth to west of Uralla, on the Northern Tablelands of N.S.W. (Figure 28).

ECOLOGY: Often forming pure stands on shallow, poor soils. Richer clay soils on basalt in the same areas carry $E$. caliginosa Blakely \& McKie.

CONSERVATION STATUS: $2 \mathrm{~V}$-. As now defined, this species is restricted mainly to productive grazing lands, and under considerable long-term threat.

\section{Eucalyptus bensonii L. Johnson \& K. Hill, sp. nov.}

Ab E. camfieldii characteribus sequentibus differt: folia juvenilia petiolata non cordata; fructus majores; alabastra longiora; folia adulta longiora angustioraque.

TYPE: New SOUTH WALES: Central Tablelands: Gospers Mtn fire trail, $8.2 \mathrm{~km} \mathrm{~S}$ of Mt Boonbourwa, D.H. Benson 1406, K. Hill \& L.A.S. Johnson, 10.5 .1983 (holo NSW).

Mallee to $8 \mathrm{~m}$ high, usually less than $6 \mathrm{~m}$, rarely single-stemmed. Bark persistent, long-fibrous ('stringybark') on lower stems to c. $4 \mathrm{~cm}$ diam., smooth above. Young stems angular. Juvenile leaves opposite, becoming disjunct, ovate or elliptical, apiculate, to 6 $\mathrm{cm}$ long, $3.5 \mathrm{~cm}$ wide, petioles $4-10 \mathrm{~mm}$ long, with dense raised glands with radiating hairs, persisting for many nodes. Adult leaves disjunct, glabrous, coriaceous, broadlanceolate, falcate, markedly oblique, obtuse and apiculate, 6-12 cm long, 2-3.5 cm wide, petioles $1-2 \mathrm{~cm}$ long; lateral veins indistinct, widely spaced, at $30-45^{\circ}$ to midrib; intramarginal vein indistinct, $1,2 \mathrm{~mm}$ from margin. Inflorescence simple, axillary; umbellasters usually 11- sometimes 7-flowered; peduncles distinctly flattened, 7-12 $\mathrm{mm}$ long, to $5 \mathrm{~mm}$ wide apically. Mature buds sessile, oblong, distinctly 2- or 3-angled, 6-8 $\mathrm{m}$ long, 3.5-4.5 mm diam. Calyptra appearing single, rounded, angular, c. $1 / 2$ as long as hypanthium. Fruit sessile, globular, 3- rarely 4-locular, 7-9 mm long, 8-12 mm diam.; calyptra scar a narrow groove; stemonophore indistinct, $0.5-1 \mathrm{~mm}$ wide, continuous with disc and hypanthium; disc domed, c. $2 \mathrm{~mm}$ wide, ultimately enclosing 
valve bases; valves broadly triangular, angled inward, enclosed or partially exserted. Seeds dull, dark brown, angular, to $2 \mathrm{~mm}$ long; chaff similar, smaller, brown (Figure 31).

E. bensonii differs from E. camfieldii Maiden in the petiolate, non-cordate juvenile leaves, the larger fruit (to $9 \mathrm{~mm}$ diam. in the latter), the oblong buds and the broadlanceolate adult leaves.

SeleCted SPECiMENS (from 7 examined): NeW South WAles: Central Tablelands: $18.2 \mathrm{~km}$ along Army Road from Coricudgy road, K. Hill 2795 \& L. Stanberg, 12.5 .1988 (NSW); $8.2 \mathrm{~km} \mathrm{~S}$ of Mt Boonbourwa on the road to Gospers Mountain, D. Benson 1379,1380,1381 \& D. Keith, 21.4.1983 (NSW); sandstone butte between Glen Davis and Glen Alice, P. Hitchcock 14, 10.9.1977 (NSW).

DISTRIBUTION: NEW SOUTH WALES: Known from isolated occurrences in the area to the east of Rylstone and Glen Davis (Figure 32).

ECOLOGY: A heathland species, growing in areas of impeded drainage in highly dissected sandstone plateau areas, often in association with $E$. sp. nov. aff. stricta Sieber ex Sprengel, E. multicaulis Blakely and a range of scleromorphic shrubs.

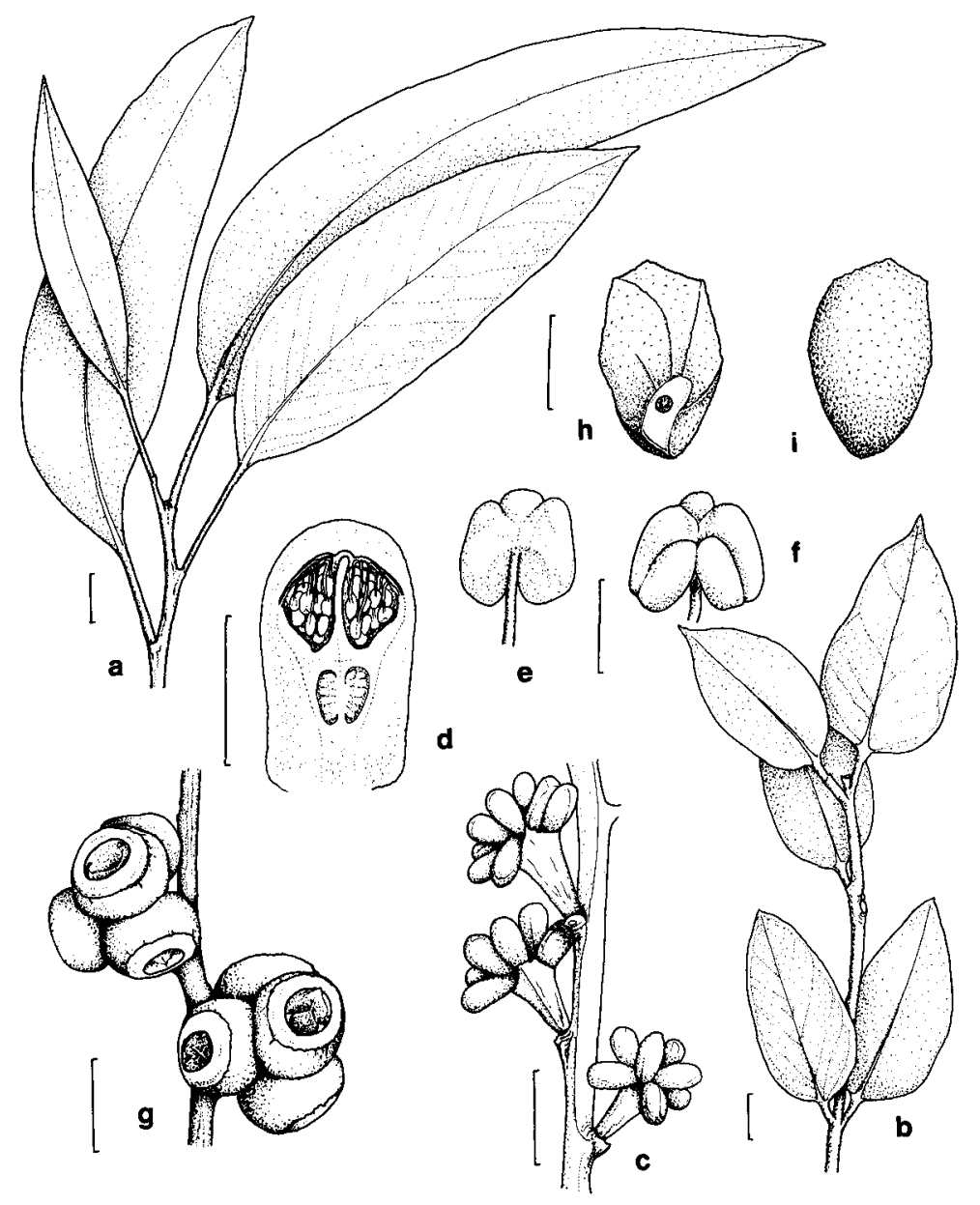

Figure 31. E. bensonii. a., adult leaves. b., juvenile leaves. c., twig with buds. d., median section of bud. e., f., anthers. g., fruit. h., i., seeds (all from D.H. Benson 1406). Scale bar: $\mathrm{a}, \mathrm{b}, \mathrm{c}, \mathrm{g}=1 \mathrm{~cm} ; \mathrm{d}$ $=4 \mathrm{~mm} ; \mathrm{e}, \mathrm{f}=0.5 \mathrm{~mm} ; \mathrm{h}, \mathrm{i}=1 \mathrm{~mm}$. 
The specific epithet honours Douglas Howard Benson, Ecologist with the National Herbarium of New South Wales, who drew attention to this taxon during a vegetation mapping program in the area in which it occurs.

CONSERVATION STATUS: 2VCt. The entire known occurrence of this species is in remote parts of the Wollemi National Park.

\section{Eucalyptus conjuncta L. Johnson $\mathcal{E}$ K. Hill, sp. nov.}

Inter species $E$. eugenioidis affines, combinatione sequenti distinguitur: folia adulta viridia concoloria; calyptra acuta sed breviuscula; fructus parvi vel mediocres cupuliformes in pedicellis longis gracilibusque.

TyPe: New SOUTH Wales: Central Western Slopes: 'Paradise Rocks', at top of ridge behind Murrurundi golf club, K. Hill 1324, 21.9.1985 (holo NSW; iso AD, BRI, CANB, CBG, K, MEL, MO, PERTH).

Tree to $15 \mathrm{~m}$ tall. Bark persistent to small branches, stringy. Juveniles leaves disjunct, lanceolate, crenulate, to $8 \mathrm{~cm}$ long, $1.5 \mathrm{~cm}$ wide, hispid with hair tufts on emergent oil glands. Adult leaves disjunct, concolorous, glossy bright green, lanceolate, $9-14 \mathrm{~cm}$ long, $1.2-2.2 \mathrm{~cm}$ wide; petioles $0.9-1.3 \mathrm{~cm}$ long; lateral veins at $30-45^{\circ}$ to midrib. Inflorescences simple, axillary; umbellasters 11- or more flowered; peduncles slender, angular, 5-10 mm long; pedicels slender, terete, 1-4 mm long. Buds fusiform, 5-7 mm long, 2-3 $\mathrm{mm}$ diam. Calyptra appearing single, as long as or slightly shorter than hypanthium, conical. Fruit cup-shaped, 4-6 mm long, 6-8 $\mathrm{mm}$ diam.

Distinguished by the combination of concolorous green adult leaves, acute but relatively short calyptra, and small to medium-size cup-shaped fruits with long, slender pedicels.

This taxon is morphologically intermediate between $E$. eugenioides Sieber ex Sprengel and $E$. sparsifolia Blakely, which both occur in parts of the upper Hunter Valley, and may have originated as a hybrid population between the two and become stabilized. It is distinguished from $E$. eugenioides by the concolorous leaves and smaller fruit (to 8 $\mathrm{mm}$ long, $9 \mathrm{~mm}$ diam. in the latter), and from E. sparsifolia by the shorter calyptra, the longer, slender pedicels, and the cup-shaped fruit.

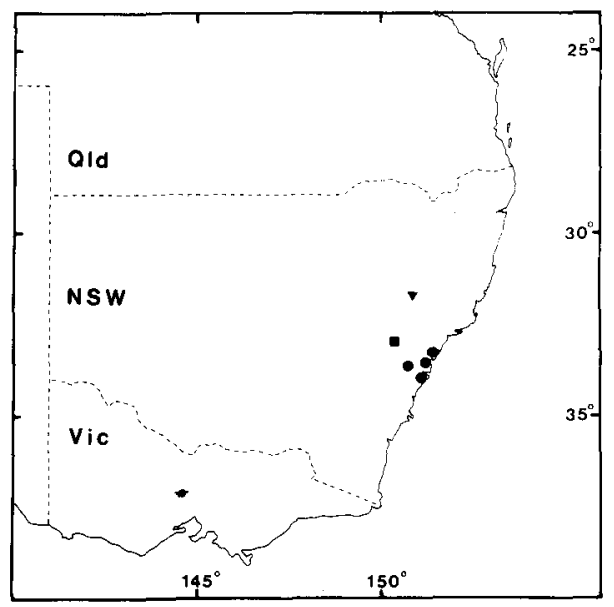

Figure 32. Distribution of $E$. bensonii (square), E. conjuncta (triangle) and $E$. oblonga (circle). 
Selected SPECimens (from 9 examined): NeW South Wales: Central Western Slopes: $3 \mathrm{~km}$ NW of Murrurundi, on New England Highway, L.A.S. Johnson 8715, 1.2.1983 (NSW); 0.5 mile [0.8 km] W of Murrurundi, R. Story 7468, 7.10.1960 (CANB, NSW); Murrurundi, E.J. Gregson, 10.11.1954 (NSW); $3.5 \mathrm{~km} \mathrm{~N}$ of Murrurundi on New England Highway, G.M. Chippendale $1232 \&$ M.J. Brennan, 10.4.1975 (CANB, NSW).

DISTRIBUTION: Known from a very restricted area around Murrurundi in the upper Hunter Valley, New South Wales (Figure 32).

ECOLOGY: Locally frequent in grassy or dry sclerophyll woodland on skeletal sandy soils on sandstone or conglomerate, usually on sloping sites or broken crests.

The epithet is from the Latin conjunctus, 'joined', in reference to the morphologically intermediate nature.

CONSERVATION STATUS: $2 \mathrm{~V}$-. Although most stands of this species are on privately held grazing land, there are occurrences in small reserves.

38. Eucalyptus oblonga $D C$., Prodr. 3: 217 (1828).

TYPE CITATION: 'Sieb! plant. exs. nov.-holl. n. 583.'

TYPE: holo G-DC; iso BM, G, NSW.

=E. deformis Blakely, J. \& Proc. Roy. Soc. New South Wales 61: 152 (1927).

TYPE CITATION: '... Kariong Trig. Station, the type locality, which is roughly about 7 miles $[11 \mathrm{~km}]$ north of Brooklyn (D.W.C. Shiress and W.F.B.)'

TYPE: NeW SOUTH WALES: $1 / 2$ mile $[0.8 \mathrm{~km}] \mathrm{S}$ of Kariong Trig, Wondabyne, W.F. Blakely $\mathcal{E}$ D.W.C. Shiress NSW 222259, 25.4.1927 (holo NSW, iso NSW). This specimen was labelled 'type' by Blakely.

Included in E. oblonga by Johnson (1962).

= E. oblonga DC. var. rugulosa Blakely, Key Eucalypts: 191 (1934).

TYPE CitATION: 'N.S.W. - Spring Gully Creek, Hornsby, W.F. Blakely, October, 1930.'

TYPE: holo NSW 222255.

E. oblonga was interpreted broadly to include E. sparsifolia by Pryor \& Johnson (1971). We would now take a narrower view and regard the two as separate taxa, with a degree of intergradation. E. oblonga as now defined is a quite restricted taxon, occurring on skeletal soils on sandstone or on residual Tertiary laterites over sandstone, for the most part on the Ourimbah and Kuring-gai plateaux. Other small occurrences are in Royal National Park and on the edges of the Woronora Plateau, and in the Kedumba Valley (Figure 32).

Distinguished from E. sparsifolia by the ovate juvenile leaves, the broad-lanceolate adult leaves and the ovoid, acute buds. Buds and fruit usually very shortly pedicellate (pedicels less than $1.5 \mathrm{~mm}$ long).

Intergrading populations with E. sparsifolia and E. capitellata $\mathrm{Sm}$. occur. Hybrids are known with $E$. pilularis $S \mathrm{~m}$. (hybrids were named $E$. wardii Blakely) and $E$. haemastoma $\mathrm{Sm}$.

Selected SPeCimens (from 49 examined): New South Wales: Central Coast: Bill Jacks Point, Red Hill Rd, Ourimbah State Forest, G.J. Power, 11.1973 (NSW); Peats Ridge, S of Mangrove Mountain, E.J. Gregson, 9.5.1953 (NSW); $3.2 \mathrm{~km}$ NNE of Berowra on Pacific Highway, G.M. Chippendale 1016 \& R. Godenzi, 30.5.1974 (CANB, NSW); S of Terry Hills, near head of Middle Creek, L.A.S. Johnson 7225, 14.6.1971 (NSW); Roseville Chase, C. Burgess, 9.5.1953 (NSW); Wises Track, Royal National Park, R. Coveny 9663a, 15.10.1977 (NSW); Bangor, P. Moore, 6.1986 (NSW); Waterfall, J.H. Maiden, 8.1906 (NSW).

CONSERVATION STATUS: Not considered to be at risk. 
39. Eucalyptus sparsifolia Blakely, Key Eucalypts: 190 (1934), as 'sparsiflora' in text. TYPE CitATION: 'N.S.W. - Glenore [sic], Maroota and Windsor districts, W.F. Blakely and D.W.C. Shiress, the type'.

TYPE: New SOUTH WALES: Glenorie to Canoe Grounds [now Canoelands], W.F. Blakely $\mathcal{E}$ D.W.C Shiress NSW 222256, NSW 222257, NSW 222258, 14.10.1927 (Lecto: NSW, 3 sheets, here designated). Although not so cited in the protologue, this collection was selected as 'type' by Blakely and clearly labelled as such, and can hence be accepted as the lectotype. The three sheets represent different phases of growth and flowering. The usage of 'sparsiflora' in the main text is clearly shown to be an unintentional error by the use of 'sparsifolia' in the key and in the index, and on all specimens annotated by Blakely.

This species has a wide range within N.S.W., from the Pilliga Scrub and upper Hunter Valley through the Central Western Slopes and Blue Mountains to the edges of the Cumberland Plain, with outliers in the upper Manning catchment (Figure 33). It occurs on sandy but somewhat more fertile and often deeper soils than E. oblonga.

E. sparsifolia is distinguished by the combination of linear juvenile leaves, narrowlanceolate to lanceolate adult leaves and narrow-fusiform, acute buds. The calyptra is narrow-conical and frequently slightly longer than the hypanthium, and buds and fruit usually very shortly pedicellate (pedicels less than $1.5 \mathrm{~mm}$ long).

Intergrading populations occur with $E$. eugenioides Sieber ex Sprengel, E. globoidea Blakely, E. oblonga and $E$. agglomerata Maiden. Hybrids are known with $E$. cannonii $\mathbf{R}$. Baker, E. ligustrina DC., E. stellulata Sieber ex DC., E. sieberi L. Johnson, E. sclerophylla (Blakely) L. Johnson \& Blaxell and E. racemosa Cav.

Selected SPECIMENS (from 138 examined): NeW SoutH WALES: North Coast: $W$ of Vinegar Mtn, $c$. $35 \mathrm{~km}$ NW of Gloucester, J. Benson, 20.8.1980 (NSW); c. 200 metres from summit of Sugarloaf (W of Newcastle), K. Hill $7.55 \&$ L. Johnson, 3.5.1984 (CANB, NSW); 6 miles [9.6 km] SE of Broke, $R$. Story 7372, 8.6.1960 (CANB, NSW). Central Coast: $5 \mathrm{~km} \mathrm{~S}$ of Bucketty, J. Pickard 856, 14.11.1970 (NSW); $6.8 \mathrm{~km}$ towards Sackville from Glenorie-Wisemans Ferry road, G. Chippendale $1013 \& R$. Godenzi, 29.5.1974 (CANB, NSW); Cheltenham, L.A.S. Johnson 834, 26.10.1946 (NSW); near golf links, Richmond Road, Springwood, G. Chippendale 1196 \& M.J. Brennan, 7.4.1975 (CANB, NSW); Londonderry road, $2 \mathrm{~km} \mathrm{~N}$ of Penrith-Windsor road, D.H. Benson 1205, 9.6.1976 (NSW).

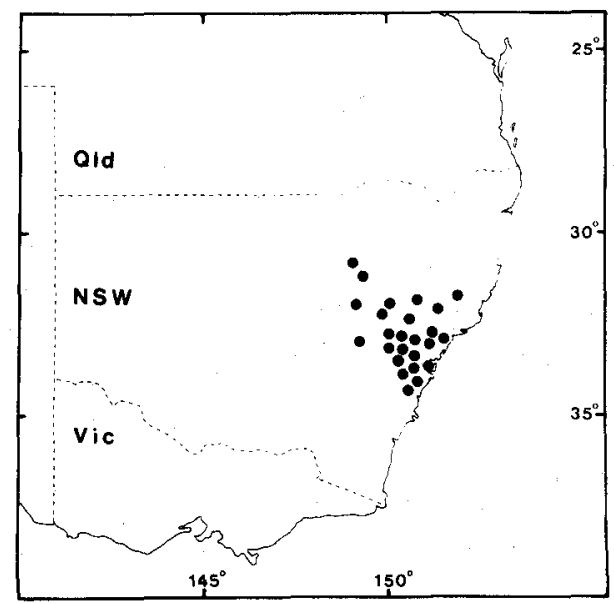

Figure 33. Distribution of E. sparsifolia. 
Central Tablelands: 7 miles [11.2 km] E of Olinda, L.A.S. Johnson, 1.9.1951 (NSW); W slopes of Mt Darcy, K. Hill 2799 \& L. Stanberg, 12.5.1988 (NSW, PERTH); NW corner of Mullion Range State Forest, B. Lane NSW 47953, 10.1959 (NSW); 2 miles [3.2 km] S of Capertee, D.O. Cross, 2.10.1938 (NSW); $3 \mathrm{~km} \mathrm{SE}$ of Cullen Bullen towards Lithgow, K.L. Wilson 2419 \& J.T. Waterhouse, 17.8.1979 (NSW); Mt Victoria, E.F. Constable NSW 11298, 20.3.1950 (NSW); Wentworth Falls, L.A.S. Johnson 948/1, 9.1948 (NSW). North Western Slopes: Baradine district, F.M. Bailey NSW 6481, 2.9.1948 (NSW). Central Western Slopes: $3.8 \mathrm{~km}$ from Cressfield Road on Middle Road, N of Scone, K. Hill 1310, 21.9.1985 (BRI, CANB, NSW, PERTH); 10 miles [ $16 \mathrm{~km}$ ] SW of Murrurundi, $R$. Story 6924, 26.11.1959 (CANB, NSW); Lees Pinch, Wollar-Merriwa road, L.A.S. Johnson NSW 17742, 19.9.1951 (NSW); $1 \mathrm{~km} \mathrm{~S}$ of Caratel Loop, Dubbo-Merrygoen railway, L.A.S. Johnson 7580 , 27.2.1973 (NSW).

CONSERVATION STATUS: Not considered to be at risk.

40. Eucalyptus radiata Sieber ex DC., Prodr. 3: 218 (1828).

Type CITATION: 'Sieb! plant. exs. nov.-holl. n. 425:'

TYPE: New Holland, F.W. Sieber 475, 1823 (holo G-DC; iso BM, FI, G, K, L, NSW, W). The collection number was wrongly cited as 425 by de Candolle.

The northern race is recognised here as a separate subspecies (although the locality is not stated on the type specimen, Sieber was known to collect only around Sydney and on the nearby Central and Southern Tablelands. The type subspecies is therefore taken to be the Central Tablelands race.). In addition, we recognise E. robertsonii Blakely and E. croajingolensis $\mathrm{L}$. Johnson \& $\mathrm{K}$. Hill as distinct taxa, and consider that some further subdivision of $E$. radiata at subspecific rank in the south of its range will probably be necessary in the future.

\section{Key to subspecies}

1 Juvenile leaves linear to lanceolate 40A. subsp. radiata

1 * Juvenile leaves broad-lanceolate 40B. subsp. sejuncta

\section{A. Eucalyptus radiata Sieber ex $D C$. subsp. radiata}

$=$ E. phellandra R. Baker \& H.G. Smith, Res. Eucalypts ed. 2: 280 (1920).

Type Citation: 'Habitat. - Barber's Creek, Batlow, Braidwood, Bundanoon, Bungendore, Burrawang, Crookwell, Hill Top, Laurel Hill, Lochiel, Marulan, Mittagong, Monga, Moss Vale, Tumberumba [sic], Tumut, New South Wales; Warburton, Victoria.' Material for oil distillation was cited as 'Monga, N.S.W., in July, $1898^{\prime}$

TYPE: NeW SouTh WALES: Moss Vale, C.J. Clulee NSW 222263, 22.11.1917 (lecto NSW, here designated). This specimen was annotated E. phellandra by Baker. Specimens collected by Clulee from Mittagong in 1921 were annotated taken from the tree at Mittagong from which the specimen supplied to Mr R.T. Baker on 22nd Nov, 1917 was obtained', and specimens collected in 1922 were annotated 'from the Type tree of $E$. phellandra '(after publication of the name). No specimen from Mittagong with this date exists, so the Moss Vale collection with the same date is selected as the lectotype.

Included in E. radiata by Maiden (Crit. Revis. Eucalyptus 7: 19).

=E. australiana R. Baker \& H.G. Smith, J. \& Proc. Roy. Soc. New South Wales 49: 514 (1916).

TYPE CITATION: None cited. The authors mention that their attention had been drawn to the tree by Mr W.T. Farrell in early 1913, who had collected specimens near Nerrigundah. However, no specimen relating to this statement can be found, and Baker 
and Smith's publication of E. amygdalina var. australiana (as a nomen nudum) predates this.

TYPE: NeW SOUTH WALES: Monga, W. Baeuerlen NSW 222261, 7.1898 (lecto NSW, here designated). This is the only specimen located that was annotated E. australiana by Baker.

$\equiv$ E. radiata Sieb. ex DC. var. australiana (R. Baker \& H.G. Smith) Blakely, Key Eucalypts: 211 (1934).

[E. amygdalina Labill. var. australiana R. Baker \& H.G. Smith, Proc. \& Trans. Roy. Soc. Tasmania: 201 (1912), nom. nud.]

Maiden (Crit. Revis. Eucalyptus 4: 230; Crit. Revis. Eucalyptus 8: 86) regarded this taxon as a mixture of specimens of E. radiata and E. robertsonii, and Blakely (1934) treated it as a variety of E. radiata. Pryor \& Johnson (1971) treated it as a minor local variant of E. radiata.

$=$ E. radiata Sieber ex DC. var. subexserta Blakely, Key Eucalypts: 211 (1934).

TYPE CITATION: 'N.S.W. - On limestone formation, McEwan's Creek, Jenolan Caves (W.F.Blakely, 18.7.1899; J.C.Wiburd, 11.1928).

TYPE: NeW South WALES: Jenolan Caves, W.F. Blakely NSW 222262, 18.7.1899 (lecto NSW, here designated). Blakely had annotated this specimen 'Type' and the other cited specimen 'Cotype'. Since a 'Cotype' is now regarded as a Paratype, his Type is accepted as the lectotype.

DistRIBUTION: Two disjunct occurrences are here included under E. radiata subsp. radiata (Figure 34). The first extends from the north-west of the Central Tablelands of New South Wales, from north of Rylstone, south through the eastern Southern Tablelands on to the higher western ranges of the far South Coast, but not extending into Victoria. The second is restricted to central Victoria, extending from the Dandenong Ranges west to about Ballarat.

Specimens are not cited for E. radiata subsp. radiata. Further study is required to

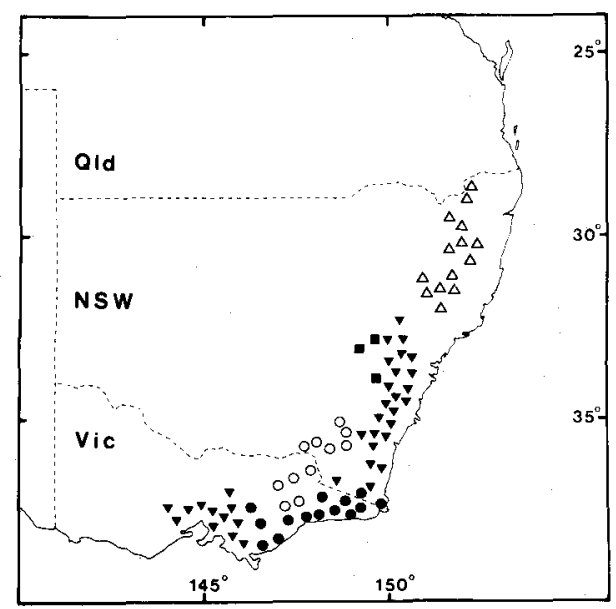

Figure 34. Distribution of $E$. radiata subsp. radiata (triangle) and subsp. sejuncta (open triangle), E. robertsonii subsp. robertsonii (open circle), and subsp. hemisphaerica (square), and E. croajingolensis (circle). 
establish the nature of this taxon in southern New South Wales and central Victoria, and further subspecific division is likely.

Intergrading populations occur with $E$. elata Dehnh. and $E$. willisii Ladiges, Humphries \& Brooker. Hybrids are known with E. eugenioides Sieber ex Sprengel, E. globoidea Blakely, E. ligustrina DC., E. fastigata Deane \& Maiden, E. pauciflora Sieber ex Sprengel (hybrids $=E$. vitrea R. Baker), E. stricta Sieber ex Sprengel, E. moorei Maiden \& Cambage, E. sieberi L. Johnson, E. sclerophylla (Blakely) L. Johnson \& Blaxell, E. rossii R. Baker \& H.G. Smith, and E. dives Schauer.

CONSERVATION STATUS: Not considered to be at risk.

40B. Eucalyptus radiata Sieber ex DC. subsp. sejuncta $L$. Johnson \& K. Hill, nom. et stat. nov.

REPLACED NAME: E. radiata Sieber ex DC. var. subplatyphylla Blakely, Key Eucalypts: 212 (1934).

Type Citation: 'N.S.W. - Aberfoyle Road, Guyra (Rev. E.N. McKie); six miles [9.6 km] south of Guyra; Butterleaf State Forest; Hanging Rock, Nundle, very common.'

TyPe: New SOUTH Wales: Aberfoyle Road, Guyra, E.N. McKie NSW 222260, 12.1932 (lecto NSW, here designated). This was the only specimen fully cited by Blakely, and the enclosing folder was annotated with the number of this taxon in his 'Key to the Eucalypts'.

Blakely's original epithet does not have priority in the changed rank of subspecies, is not particularly appropriate and is confusable with the name of the very different species E. platyphylla F. Muell.

Distinguished by the broad-lanceolate to narrow-ovate juvenile leaves.

The fruit is larger in more southern examples of subsp. sejuncta, possibly partly due to some introgression from $E$. dives.

Hybrids are known with E. campanulata R. Baker \& H.G. Smith.

SELECTED SPECIMENS (from 44 examined): NEW SOUTH WALES: Northern Tablelands: Wilsons Downfall, J.L. Boorman, 11.1904 (NSW); c. 0.5 miles $[0.8 \mathrm{~km}]$ E of Tenterfield towards Boonoo Boonoo, M.I.H. Brooker 3952, 2.3.1973 (CANB, NSW); c. $1 \mathrm{~km}$ from Paddys Gully road on Glencoe road, Backwater, K. Hill 1334, 21.1.1986 (BRI, CANB, NSW, PERTH); Marengo, J.F. Campbell, 3.1907 (NSW); $2.5 \mathrm{~km}$ E of Exmouth rail crossing, K. Hill 1325, 25.12.1985 (CANB, NSW, MEL, PERTH); Styx River S.F. road, 13.1 miles [20 km] from Armidale-Kempsey road, M.I.H. Brooker 6073, 23.1.1979 (CANB, NSW); $21.4 \mathrm{~km}$ E of Apsley Falls turnoff on Oxley Highway, G.Chippendale $1258 \mathcal{E}$ M.J. Brennan, 12.4.1975 (CANB, NSW); 1 mile N of Glen Morrison, L.A.S. Johnson NSW 222319, 21.5.1957 (NSW); Kangaroo Tops, Tomalla Tableland, H. McDonald 9, 1.9.1954 (NSW).

DisTRIBUTION: Elevated eastern parts of the Northern Tablelands of New South Wales, from north-east of Tenterfield to the north-eastern Barrington Tops (Figure 34).

ECOLOGY: This taxon shows a scattered distribution in dry sclerophyll or grassy forests, usually on deeper and lighter soils in areas of moderately high rainfall. Very frequently associated with E. campanulata R. Baker \& H.G. Smith.

The epithet is from the Latin sejunctus 'separate', in reference to the disjunct distribution from the other races of $E$. radiata. 


\section{Eucalyptus croajingolensis L. Johnson \& K. Hill, sp. nov.}

$\mathrm{Ab} E$. radiata foliis adultis juvenilibusque latis, alabastris foliisque glaucis et disco fructus aliquantum latiore distinguitur. $\mathrm{Ab}$ E. robertsonii foliis adultis juvenilibusque latioribus et calyptra hemisphaerica distinguitur.

TYPE: VICTORIA: $20.5 \mathrm{~km}$ from Orbost on Bonang Highway, K. Hill 1375, L. Johnson \& D. Albrecht, 18.2.1986 (holo NSW; iso CANB, MEL, PERTH).

Tree to $30 \mathrm{~m}$ tall. Bark fully persistent, dark grey, finely fibrous ('peppermint'). Juvenile leaves opposite, glaucous, sessile, \pm cordate, oblong-elliptical, to $9 \mathrm{~cm}$ long, $3 \mathrm{~cm}$ wide. Intermediate leaves disjunct, \pm glaucous, elliptical or broad-lanceolate, to $20 \mathrm{~cm}$ long, 5 $\mathrm{cm}$ wide, frequently appearing as reversions in crowns of mature trees. Adult leaves disjunct, usually broad-lanceolate, sometimes lanceolate, dull, distinctly bluish, 8-18 $\mathrm{cm}$ long, $1.2-4 \mathrm{~cm}$ wide, petioles flattened, $1.0-2.5 \mathrm{~cm}$ long. Lateral veins widely spaced, at $20-40^{\circ}$ to midrib, reticulation open, with more than one oil gland per vein

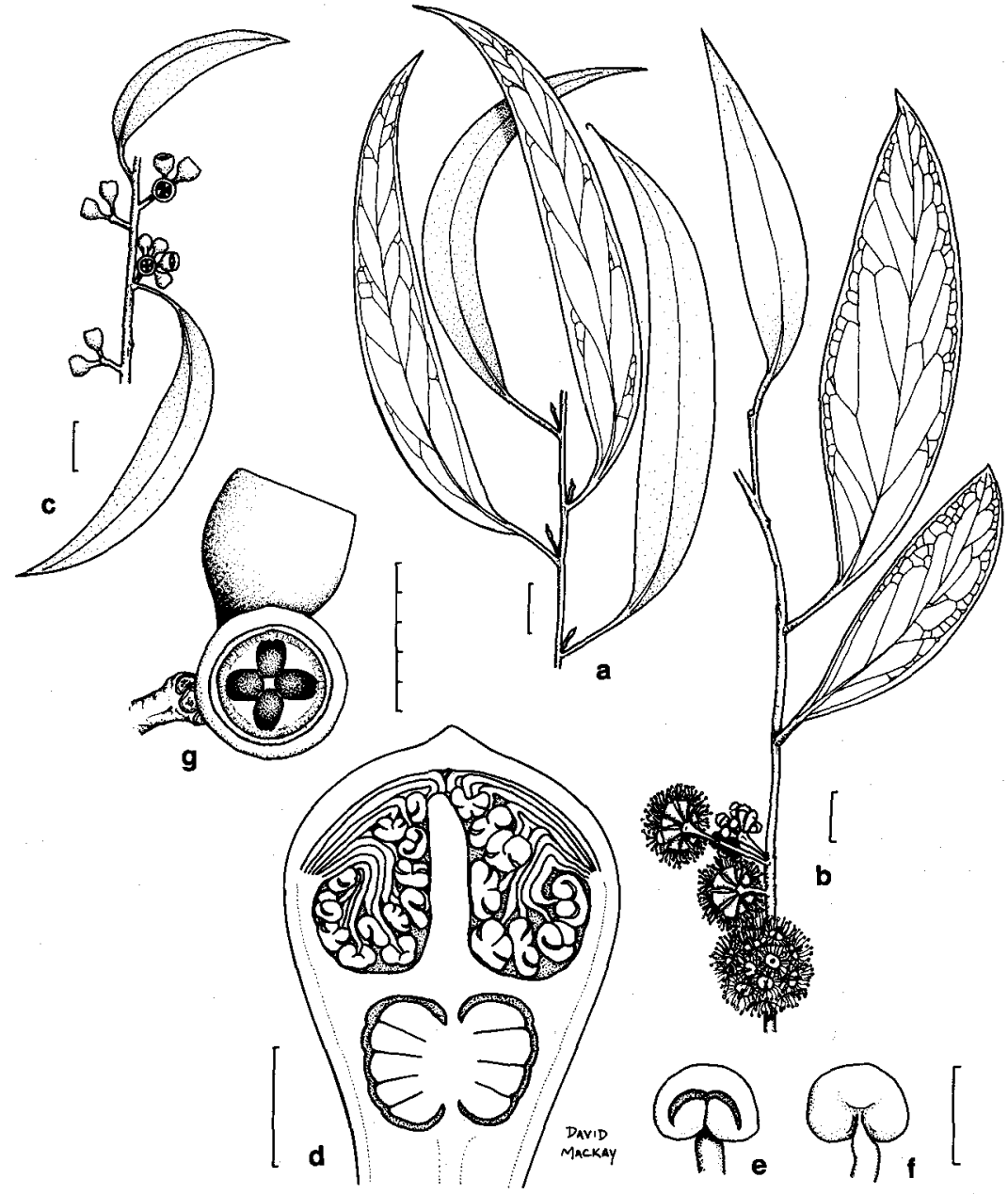

Figure 35. E. croajingolensis. a. adult leaves. b. reversionary adult leaves with buds and flowers. c. twig with fruit. d. median section of flower. e. f. anthers. g. fruit (a, c, g from C. Debenham, 3.1960 , b, d, e, f from M.I.H. Brooker 7789). Scale bar: a, b, c = $1 \mathrm{~cm} ; \mathrm{d}=1 \mathrm{~mm} ; \mathrm{e}, \mathrm{f}=0.5 \mathrm{~mm}$; $\mathrm{g}=5 \mathrm{~mm}$. 
island. Intramarginal vein distinct, \pm looped, 1-4 mm from margin, often with a distinct secondary intramarginal vein nearer the margin. Inflorescences simple, axillary; umbellasters 11- to more than 20-flowered; peduncles 4-15 mm long; pedicels 2-4 mm long. Buds glaucous, clavate, 3-5 mm long, 1.5-3 mm diam. Calyptra appearing single, hemispherical to patelliform, often finely apiculate, about half as long as hypanthium. Fruit 3-4-locular, globular-truncate, 4-6 mm long, 4-6 mm diam. Calyptra scar and stemonophore reduced to a fine line; disc level, c. $1 \mathrm{~mm}$ wide. Valves broadly triangular, enclosed or sometimes apically rim-level (Figure 34).

Distinguished from $E$. radiata by the broad-lanceolate, dull bluish adult and juvenile leaves, the glaucous buds and adult and juvenile foliage, and the somewhat broader, flatter disc in the fruit. Distinguished from E. robertsonii Blakely by the broadlanceolate adult and juvenile leaves. The frequent appearance of broad, pendulous reversion leaves in mature undamaged canopy is a feature of this species.

Intergradation with E. radiata occurs on the eastern Southern Tablelands of New South Wales, and with $E$. robertsonii in parts of the Victorian highlands. There is apparently a sharp transition to $E$. radiata east of Melbourne.

SELECTED SPECIMENS (from 39 examined): New SOUTH WALES: South Coast: Timbillica, 200 metres E of homestead, K. Hill 1364 \& L. Johnson, 17.2.1986 (CANB, NSW, PERTH, MEL); approach to Mt Imlay, M.I.H. Brooker 6796, 15.1.1980 (CANB, NSW). Southern Tablelands: The Gums, Bombala, L.D. Pryor, 30.3.1982 (NSW); Nalbaugh State Forest, L.D. Pryor, 30.3 .1982 (NSW). VICTORIA: Poddy [as Poddys] Creek, on Princes Highway, M.I.H. Brooker 7012,7013, 26.10.1981 (CANB, NSW); $23 \mathrm{~km} \mathrm{~W}$ of Delegate on road to Tubbut, L.D. Pryor \& J.D. Briggs 212, 8.2.1979 (CANB, NSW, MEL); Boggy Creek, Buchan road, J.H. Maiden, 7.1908 (NSW); c. $10 \mathrm{~km}$ along S Gippsland Highway towards Korumburra, M.I.H. Brooker 7789, 27.11.1982 (CANB, NSW); Between Sale and Longford, S Gippsland Highway, C. Debenham, 3.1960 (NSW); $4.4 \mathrm{~km}$ NNE of Yarram towards Traralgon, G.M. Chippendale 988 \& M.J. Beeston, 2.5.1974 (CANB, NSW); 10.0 $\mathrm{km} \mathrm{W}$ of Seaton, K. Hill 1406, L. Johnson \& D. Albrecht, 19.2.1986 (NSW).

Distribution: A species from the coastal side of the main divide, ranging from the far South Coast and Southern Tablelands of New South Wales (Bombala to Timbillica) through east Gippsland in Victoria, west to the vicinity of Mt Useful (Figure 34).

ECOLOGY: A species of sclerophyllous woodlands or forests on lighter soils in somewhat sheltered sloping sites on the coast and near-coastal ranges.

The epithet is from the district (and county) of Croajingolong, in East Gippsland. This name is deliberately clipped before adding the Latin suffix -ensis.

CONSERVATION STATUS: Not considered to be at risk.

42. Eucalyptus robertsonii Blakely, J. \& Proc. Roy. Soc. New South Wales 61: 167 (1927), as 'robertsoni'.

TYPE CITATION: 'Talbingo Mountain, Tumut district (A.W. Howitt, C.C. Robertson and W.A.W. de Beuzeville). The type.'

TYPE: New SOUTH WALES: Talbingo Mountain, near Tumut, C.C. Robertson \& W.A.W. de Beuzeville, 9.1924 (holo NSW 132542). Blakely erroneously cited A.W. Howitt (who died in 1908) as a co-collector of the type with Robertson and de Beuzeville.

$\equiv$ E. radiata Sieber ex DC. subsp. robertsonii (Blakely) L. Johnson \& Blaxell, Contrib. New South Wales Natl Herb. 4: 380 (1973).

The names E. amygdalina, E. australiana, E. numerosa and E. phellandra have all been applied to this taxon, although the types of all of these names belong to other taxa.

Distinguished within the $E$. radiata group by the combination of linear to narrowlanceolate adult and juvenile leaves, glaucous leaves and buds, and (in the type 
subspecies) the conical calyptra. This taxon has previously been included in E. radiata. We now regard it as sufficiently distinct to warrant recognition as one of several closely-related and rather narrowly-defined species composing the 'radiata group'.

The calyptra is shorter and rounded in northern populations of this species, which can on this basis be recognised as a subspecies.

\section{Key to subspecies}

1 Calyptra conical 42A. subsp. robertsonii

1 Calyptra hemispherical 42B. subsp. hemisphaerica

\section{A. Eucalyptus robertsonii Blakely subsp. robertsonii}

Hybrids are known with E. macrorhyncha F. Muell., E. pauciflora Sieber ex Sprengel and $E$. dives Schauer (hybrids $=E$. radiodives R.A. Black).

SELECTED SPECIMENS (from 77 examined): NEW SOUTH WAIES: Southern Tablelands: Batlow, $P$. Murphy, 3.1938 (NSW, several sheets); $9.5 \mathrm{~km}$ from Naas-Tharwa road on Honeysuckle Creek road (A.C.T.), R. Coveny 11559 \& P. Hind, 20.1.1983 (CANB, NSW, K); 12 miles [19.2 km] E of Tumut, M.I.H. Brooker 2968, 10.3.1971 (CANB, NSW); $8.1 \mathrm{~km}$ from Cabramurra-Kiandra road on Ravine road ( $\left.35^{\circ} 53^{\prime} \mathrm{S} 148^{\circ} 26^{\prime} \mathrm{E}\right)$, K. Hill 738, L. Johnson \& L. Pryor, 27.4.1984 (CANB, NSW); Ingebyra, A.B. Costin, 6.11.1948 (NSW). VICTORIA: Porepunkah, J.H. Leigh S 539, 6.1.1968 (NSW); $6.4 \mathrm{~km} \mathrm{~W}$ of Mt Beauty towards Bright, G.M. Chippendale 964 \& M.J. Beeston, 29.4.1974 (CANB, NSW); Glen Wills, and Glen Wills road, H. Hopkins, 1.8.1912 (NSW); 14 miles [22 km] from Corryong towards Omeo, C.R. Dunlop CBG039648, 4.1.1969 (CBG, NSW).

DISTRIBUTION: A taxon of somewhat sporadic occurrence but often quite abundant, mostly on the western fall of the Southern Tablelands of New South Wales south from around Batlow, and the inland side of the Great Dividing Range in Victoria between Mansfield and Omeo (Figure 34).

ECOLOGY: Usually in closed grassy woodlands in locally more sheltered sites.

CONSERVATION STATUS: Not considered to be at risk.

42B. Eucalyptus robertsonii Blakely subsp. hemisphaerica L . Johnson \& K. Hill, subsp. nov.

A subspecies robertsonii calyptra hemisphaerica distinguitur.

TYPE: NeW SOUTH WALES: Central Tablelands: $1 \mathrm{~km} \mathrm{~N}$ of Mullion Creek on $\mathrm{N}$ of railway, L.A.S. Johnson 8231 \& B.G. Briggs, 10.11 .1975 (holo NSW; iso K, CANB).

Distinguished by the hemispherical calyptra.

SElECTED SPECIMENS (from 12 examined): NeW SOUTH WALES: Central Tablelands: Glengowan, Upper Meroo, J.L. Boorman \& A. Murphy 9966, 1.1913 (NSW); 1.1 miles [1.8 km] NE of Mullion Creek, R. Coveny 4170, 15.4.1974 (NSW); W of Bocoble Mtn, L.A.S. Johnson NSW 17737, 9.11.1951 (NSW); Burraga, F.W. Wakefield, 3.7.1918 (NSW).

Distribution: Central Tablelands of New South Wales, to the east and south-east of Orange (Figure 34).

ECOLOGY: Usually in closed grassy woodlands in locally sheltered sites.

The epithet is from the Latinised Greek hemisphaericus, 'hemispherical', referring to the calyptra.

CONSERVATION STATUS: $2 \mathrm{~V}$. Populations are localised and under some threat from pastoral activity. 
43. Eucalyptus latiuscula (Blakely) L. Johnson \& K. Hill, comb. et stat. nov.

BASIONYM: E. moorei Maiden \& Cambage var. latiuscula Blakely, Key Eucalypts: 207 (1934).

TYPE Citation: 'N.S.W. - On the eastern side of the forest Dividing Range, head of Tuross River, about 16 miles [ $25.6 \mathrm{~km}$ ] easterly from Nimitybelle [Nimmitabel], N.S.W. (R.H. Cambage, No. 1981).'

TYPE: holo NSW; iso CANB.

E. latiuscula is intermediate between E. stellulata Sieber ex DC. and E. moorei Maiden \& Cambage. It differs from $E$. stellulata in the smaller, lanceolate adult leaves and the mallee habit; and from $E$. moore $i$ in the ovate juvenile leaves and lanceolate adult leaves (both juvenile and adult leaves are linear to narrow-lanceolate in E. moorei), the nearsessile umbellasters and the stouter, fewer-stemmed habit. No intergrading forms are known (Figure 36).

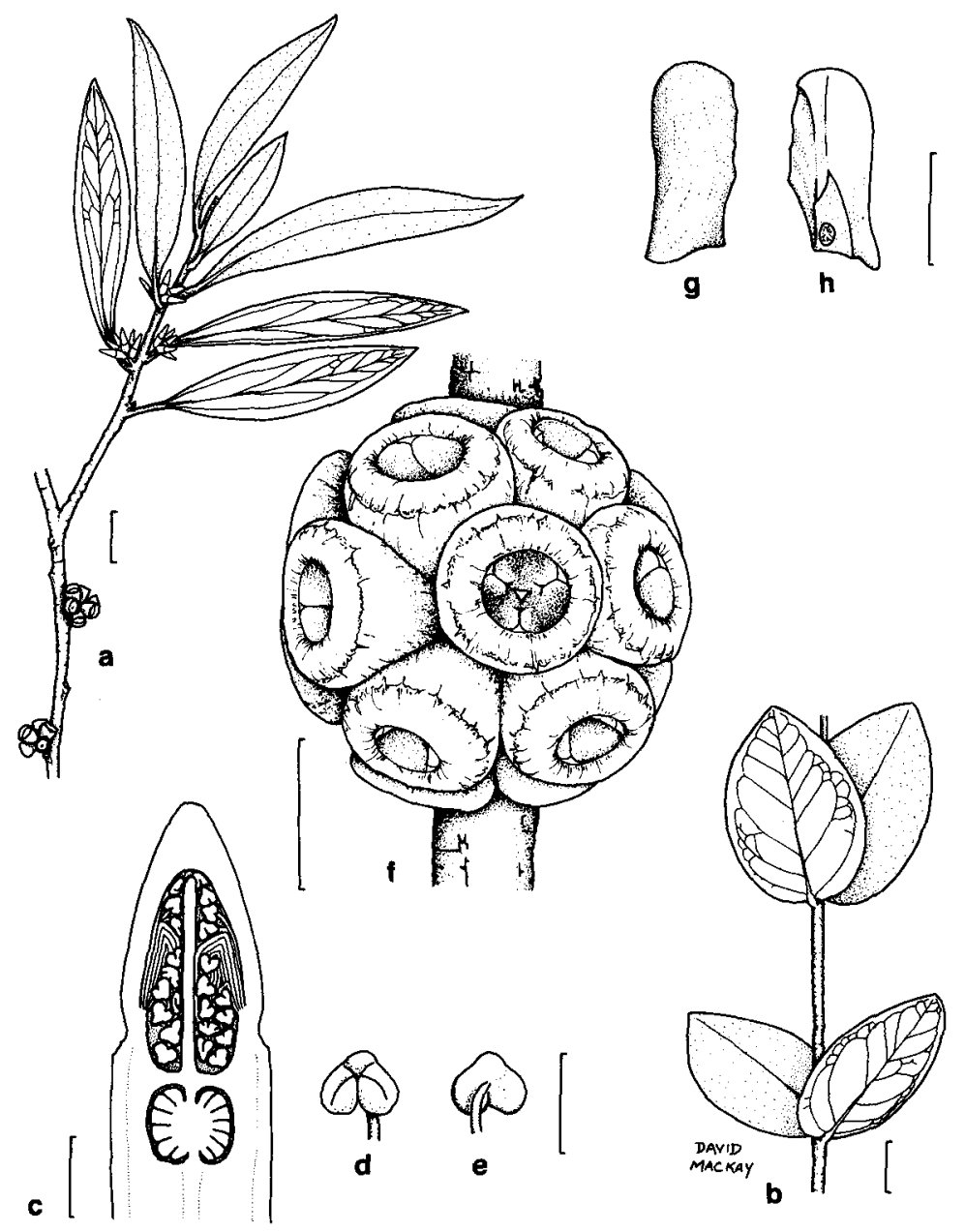

Figure 36. E. latiuscula. a. adult leaves, buds and fruit. b. juvenile leaves. c. median section of bud. d., e. anthers. f. fruit. g., h. seeds (all from J.D. Briggs 206). Scale bar: $a, b=1 \mathrm{~cm} ; \mathrm{c}, \mathrm{g}, \mathrm{h}=$ $1 \mathrm{~mm} ; \mathrm{d}, \mathrm{e}=0.5 ; \mathrm{mm} \mathrm{f}=5 \mathrm{~mm}$. 
Confusion has surrounded the name latiuscula due to the inclusion of broad-leaved individuals and hybrids of $E$. moore $i$ in the original circumscription of $E$. moore $i$ var. latiuscula. As recognised here, the two are distinctly geographically separated, and are defined also on distinct differences in juvenile leaf characters that do not overlap.

SELECTED SPECIMENS (from 20 examined): NEW SOUTH WALES: Southern Tablelands: Tinderry Range, c. $1.5 \mathrm{~km} \mathrm{~N}$ of road, K. Hill 1349 \& L. Johnson, 16.2.1986 (CANB, MEL, NSW, PERTH); c. 500 metres $S$ of southernmost peak on the main Tinderry Range, J.D. Briggs 206, 207, 208, 1.8.1978 (CANB, NSW); $13.9 \mathrm{~km}$ from Countegany-Kybean road on Wadbilliga trig. road, K. Hill 1355 \& L. Johnson, 16.2.1986 (CANB, MEL, NSW, PERTH); Nalbaugh National Park, White Rock Plateau, between Mt Wog Wog and White Rock, D.E. Albrecht 1637, 26.3.1985 (NSW, MEL).

DistribUTION: Southern Tablelands of New South Wales, small populations on the Tinderry Range, Wadbilliga Mountain and White Rock Mountain (Figure 37).

ECOLOGY: An uncommon species, occurring in small populations on shallow soil with impeded drainage, in sclerophyllous scrub or sclerophyll woodland communities. Associated species include E. pauciflora Sieber ex Sprengel, E. kybeanensis Maiden \& Cambage, E. nitens (Deane \& Maiden) Maiden, E. fraxinoides Deane \& Maiden, E. paliformis L. Johnson \& Blaxell and E. glaucescens Maiden \& Blakely.

CONSERVATION STATUS: 3RC. Almost all populations are in remote areas within national parks.

\section{Eucalyptus olida L. Johnson \& K. Hill, sp. nov.}

$\mathrm{Ab}$ E. campanulata characteribus sequentibus differt: folia juvenilia minora, rotundiora; fructus majores, cupuliformes; cortex crassior et mollior.

TYPE: New SOUTH WALES: Northern Tablelands: $4.2 \mathrm{~km}$ from the Gwydir Highway on the north-west fire trail, Gibraltar Range Natl Park (29 $\left.31^{\prime} \mathrm{S} 152^{\circ} 15^{\prime} \mathrm{E}\right)$, K. Hill $1276 \mathcal{E}$ L. Johnson, 10.9.1985 (holo NSW; iso CANB, MEL).

Tree to $30 \mathrm{~m}$ tall. Bark persistent, thick, flaky-stringy, orange-brown; smaller branches smooth, grey. Juvenile leaves disjunct, petiolate, ovate or elliptical, falcate, twisted vertically, apically rounded and often finely apiculate, to $7 \mathrm{~cm}$ long, $5 \mathrm{~cm}$ wide. Adult leaves disjunct, lanceolate to broad-lanceolate, falcate, grey-green, dull to semiglossy,

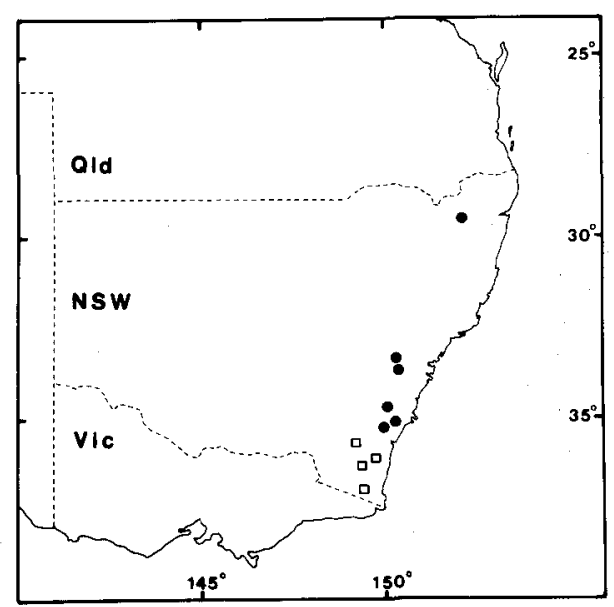

Figure 37. Distribution of E. moorei (circle) and E. latiuscula (open square). 
$8-17 \mathrm{~cm}$ long, $1.2-2.6 \mathrm{~cm}$ wide; lateral veins moderately spaced, at $30-50^{\circ}$ to midrib; intramarginal vein distinct, 1-2 $\mathrm{mm}$ from margin. Inflorescences simple, axillary; umbellasters 7-11-flowered; peduncles 8-18 mm long; pedicels 2-6 mm long. Buds clavate, 3-5 $\mathrm{mm}$ long, 2-3 mm diam. Calyptra appearing single, persistent to anthesis, shorter than hypanthium, hemispherical, often finely apiculate. Filaments irregularly flexed, of equal length; anthers all fertile, reniform, dehiscing by confluent slits. Style long (touching calyptra in bud). Fruit campanulate to cup-shaped, 4-locular, 5-8 mm long, 5-7 mm diam.; calyptra and stamen scars flat, to $0.5 \mathrm{~mm}$ wide, continuous with disc; disc flat to slightly depressed, 1-1.5 mm wide, often glossy reddish-brown; valves enclosed. Seeds black, reniform or D-shaped; chaff similar in shape, brown, smaller (Figure 38).

Distinguished from E. campanulata R. Baker \& H.G. Smith by the smaller, ovate and apically rounded juvenile leaves, the larger, more cup-shaped fruit (to $6 \mathrm{~mm}$ long, 5 $\mathrm{mm}$ diam. in E. campanulata), and the thicker, softer persistent bark. The distinctive odour (see below) is lacking in the former species. The leaves of $E$. olida also have

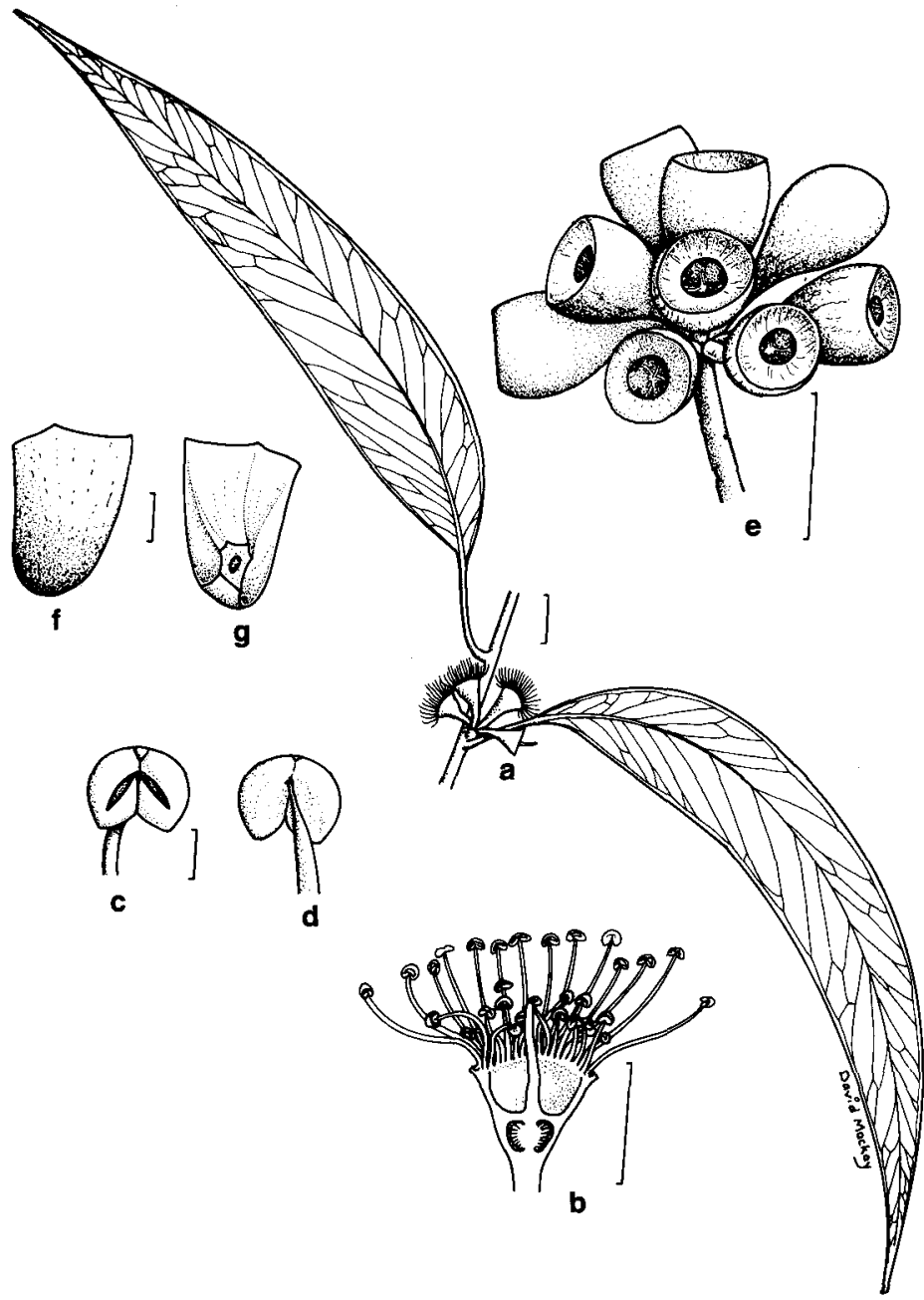

Figure 38. E. olida. a. adult leaves with flowers. b. median section of flower. c., d. anthers. e. fruit. f., g. seeds (all from A.G. Floyd 833). Scale bar: $a, e=1 \mathrm{~cm} ; b=5 \mathrm{~mm} ; \mathrm{c}, \mathrm{d}=0.5 \mathrm{~mm} ; \mathrm{f}, \mathrm{g}=1 \mathrm{~mm}$. 
smaller and more numerous stomata, and less acute venation than those of $E$. campanulata.

This taxon has been known for some time by forestry workers in the Tenterfield district, who recognised two sympatric taxa from the Timbarra Plateau as 'blackbutt' ( $E$. campanulata) and 'swamp mahogany' ( $E$. olida). It was also independently discovered by Ian Southwell of the New South Wales Department of Agriculture, who recognised two very different essential oil types in specimens collected as E. campanulata from the Gibraltar Range (pers. comm., Curtis, Southwell \& Stiff 1990). E. olida has since been shown to carry a substantial quantity of methyl cinnamate in the leaves, a compound otherwise very restricted in the eucalypts. This is responsible for the distinctive pungent odour to which the specific epithet alludes. The species is probably not particularly closely related to E. campanulata or E. andrewsii Maiden, but its closest affinities are as yet uncertain.

Selected SPECIMENS (from 19 examined): New SOUth Wales: Northern Tablelands: $3 \mathrm{~km} \mathrm{~N}$ of Poverty Point, A.G. Floyd 833, 18.1.1978 (NSW); $16.2 \mathrm{~km}$ from Bruxner Highway on Poverty Point road $\left(29^{\circ} 02^{\prime} \mathrm{S} 152^{\circ} 15^{\prime} \mathrm{E}\right), K$. Hill $1281 \&$ L. Johnson, 10.9 .1985 (NSW); $6.5 \mathrm{~km}$ NNW of Surface Hill $\left(29^{\circ} 04^{\prime}\right.$ ' $\left.152^{\circ} 15^{\prime} \mathrm{E}\right)$, D.j. Wood 11, 3.10.1984 (NSW); Mulligans Hut region, Gibraltar Range National Park, 1. Southwell H85-026, 17.9.1985 (NSW).

DistRIBUtION: Known from two disjunct populations, on the Gibraltar Range and on the Timbarra Plateau ('Poverty Point'), in the eastern Northern Tablelands of N.S.W. (Figure 39).

ECOLOGY: A component of sclerophyllous forests on infertile, moderately deep, coarsely sandy soils on siliceous 'acid' granites, often but not always in lower sites or near (but not in) swamps. Associated with E. ligustrina DC., and in both areas occurring in a mosaic with E. campanulata - E. cameronii Blakely \& McKie forests on slightly more fertile soils.

The epithet is from the Latin olidus, 'smelling' or 'rank', in reference to the distinctive, pungent and unpleasant odour of the leaf oils.

CONSERVATION STATUS: 3RC. Extensive populations occur in Gibraltar Range National Park.

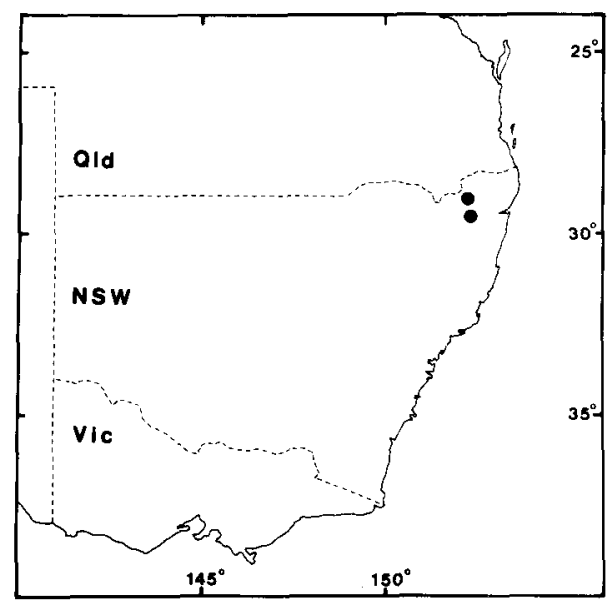

Figure 39. Distribution of E. olida. 


\section{Acknowledgements}

Thanks are due to Leonie Stanberg, who has provided invaluable assistance through the project and drafted the distribution maps. David Mackay prepared the excellent illustrations. Our colleague in the overall project, Don Blaxell, has contributed helpful discussions on many points and has been involved in the recognition of several of the taxa. Lani Retter provided much assistance in earlier stages of the investigations. The work was in part supported by grants from the Australian Biological Resources Study, which are gratefully acknowledged, as are the facilities made available to the senior author by Professor Carrick Chambers, Director of the Royal Botanic Gardens.

\section{References}

Anderson, R.H. (1956) The Trees of New South Wales, 3rd ed. (Govt. Printer: Sydney).

Bentham, G. (1867) Flora Australiensis, vol. 3 (L. Reeve: London).

Blake, S.T. (1953) Botanical contributions of the northern Australia regional survey - I. Studies on northern Australian species of Eucalyptus. Austral. J. Bot. 1: 185-352.

Blakely, W.F. (1934) A Key to the Eucalypts. (The Worker Trustees: Sydney).

Briggs, J.D. \& Leigh, J.H. (1988). Rare or Threatened Australian Plants. Australian National Parks and Wildlife Service: Special Publication 14.

Brooker, M.I.H. (1988) Eucalyptus foecunda revisited, and six related new species (Myrtaceae). Nuytsia 6(3): 325-334.

Brooker, M.I.H. \& Hopper, S.D. (in press) A taxonomic revision of Eucalyptus wandoo Blakely, E. redunca Schauer, and allied species (E. series Levispermae Maiden - Myrtaceae) in Western Australia. Nuytsia.

Brooker, M.I.H \& Kleinig, D.A. (1983) A field guide to Eucalyptus Volume 1 (Inkata Press: Melbourne).

Chappill, J.A. (1988) A systematic study of Eucalyptus L'Hérit. informal subgenus Symphyomyrtus section Maidenaria (Myrtaceae). (University of Melbourne: unpublished PhD thesis).

Chippendale, G.M. (1988) Flora of Australia Volume 19, Eucalyptus, Angophora (Myrtaceae) (Australian Government Publishing Service: Canberra).

Curtis, A, Southwell, I.A. \& Stiff, I.A. (1990) Eucalyptus, a new source of methyl cinnamate. J. Essential Oil Research 2: 105-110.

Johnson, L.A.S. (1962) Studies in the taxonomy of Eucalyptus. Contrib. New South Wales Natl Herb. 3: 103-126.

Johnson, L.A.S. \& Briggs, B.G. (1984) Myrtales and Myrtaceae - a phylogenetic analysis. Ann. Missouri Bot. Gard. 71: 700-756.

Maiden, J.H. (1903-33) A Critical Revision of the Genus Eucalyptus. (Govt. Printer: Sydney).

McVaugh, R. (1968) The genera of American Myrtaceae - an interim report. Taxon 17: 354-418.

Pryor, L.D. \& Johnson, L.A.S. (1971) A Classification of the Eucalypts. (ANU Press: Canberra).

\section{Index}

New names and combinations are printed in boldface; synonyms are printed in italics.

Species

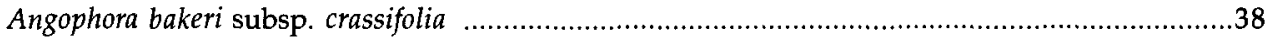

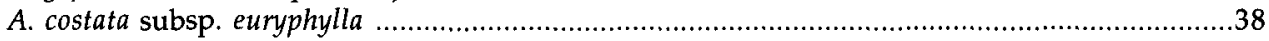

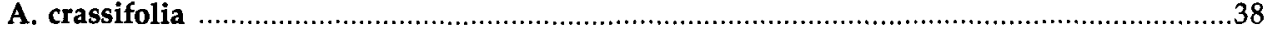

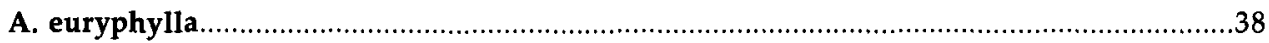

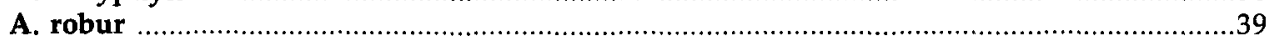

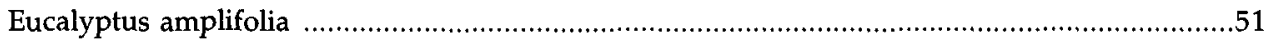




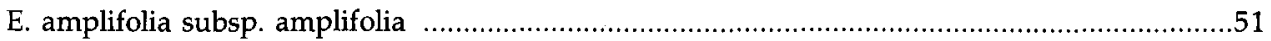

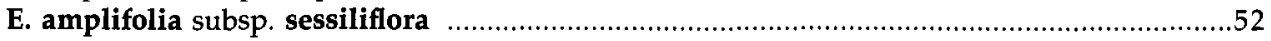

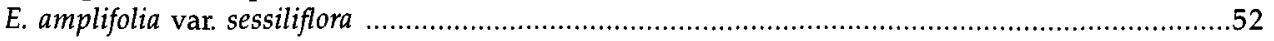

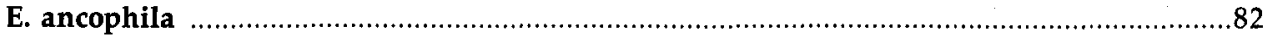

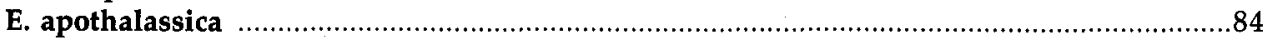

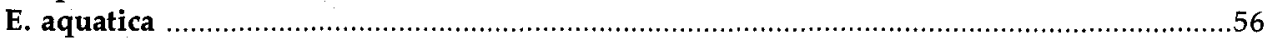

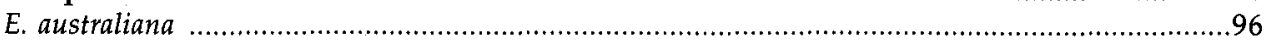

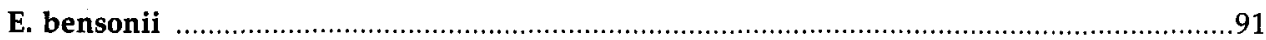

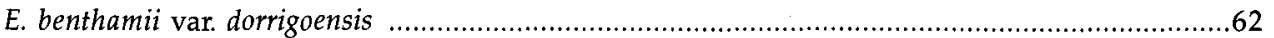

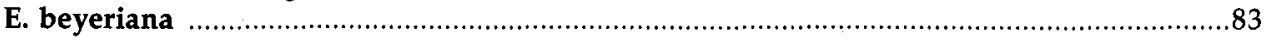

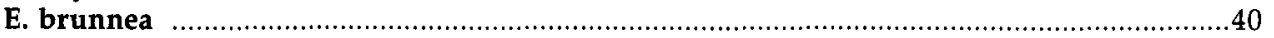

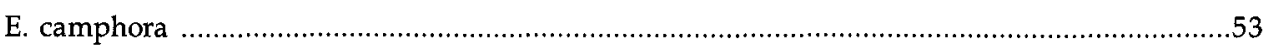

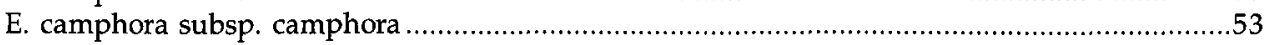

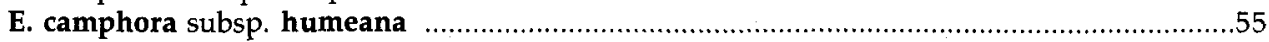

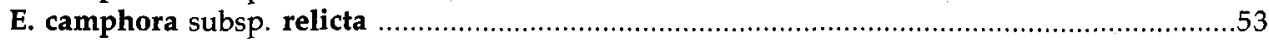

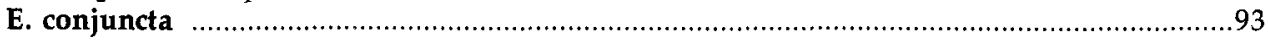

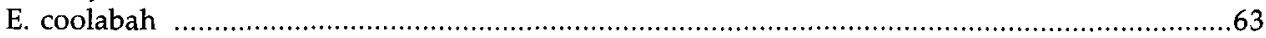

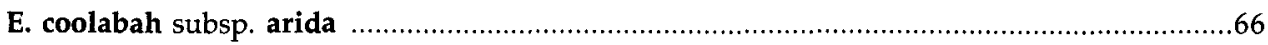

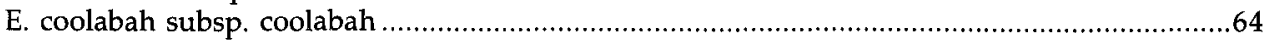

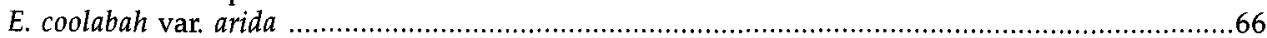

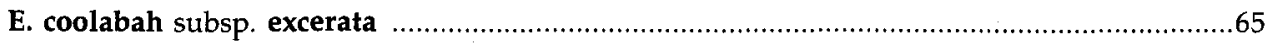

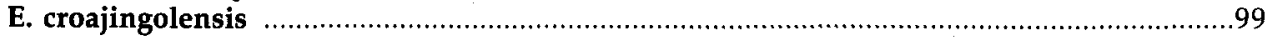

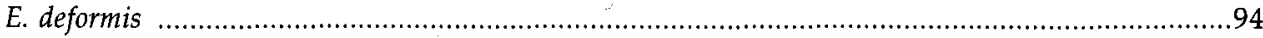

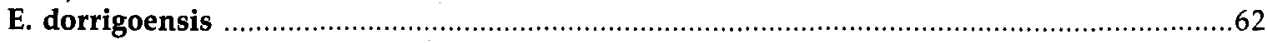

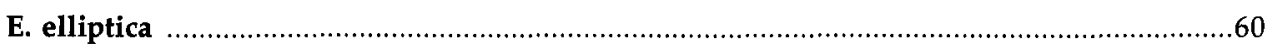

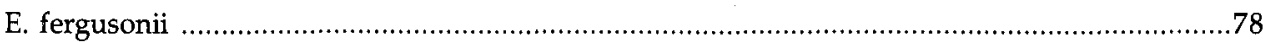

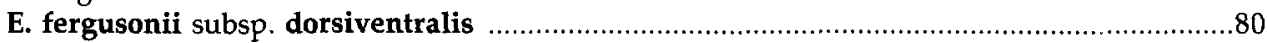

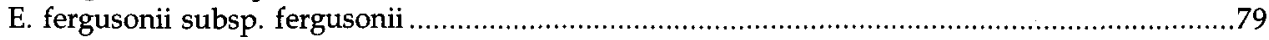

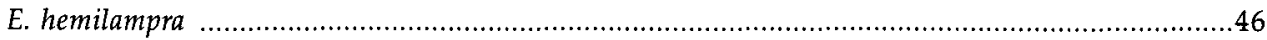

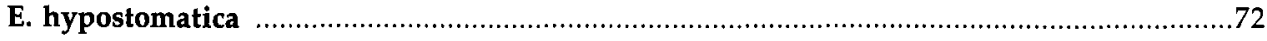

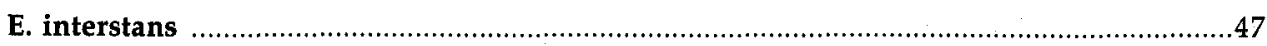

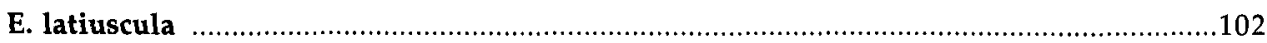

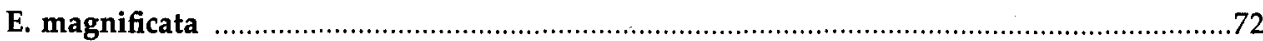

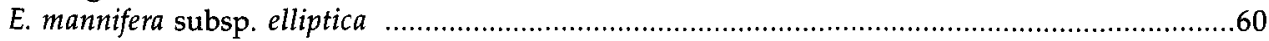

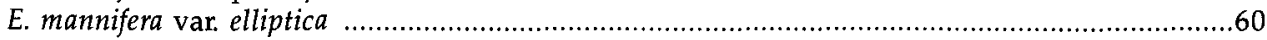

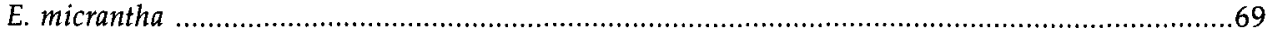

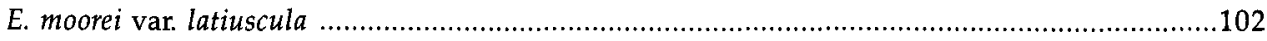

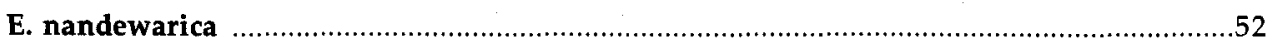

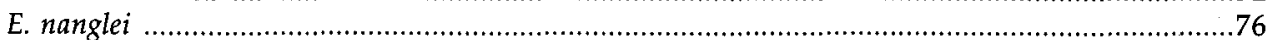

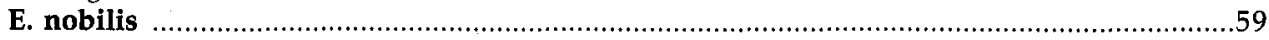

E. oblonga

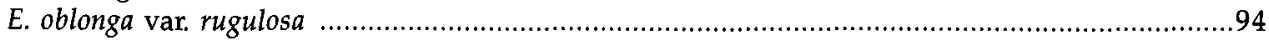

E. olida

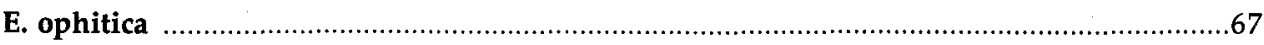

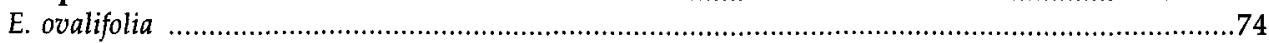

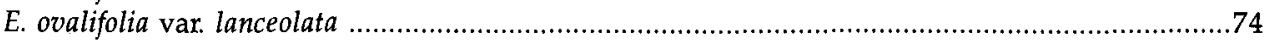




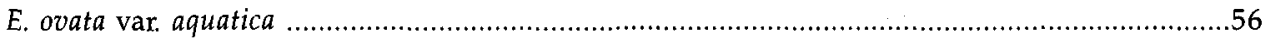

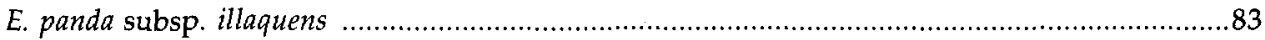

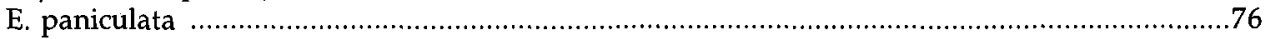

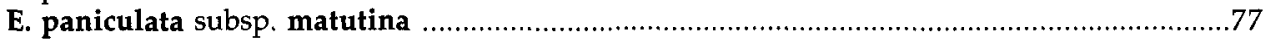

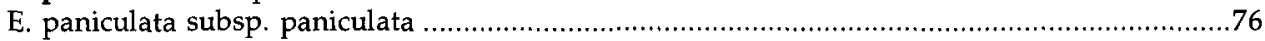

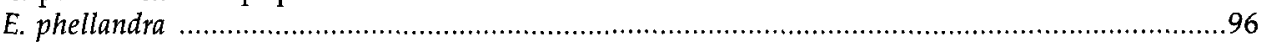

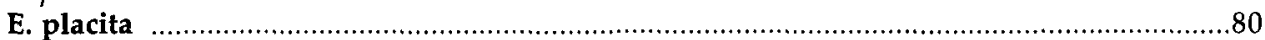

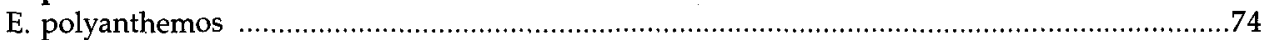

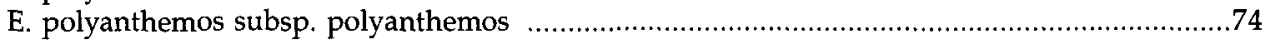

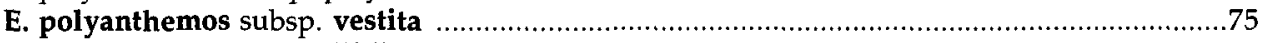

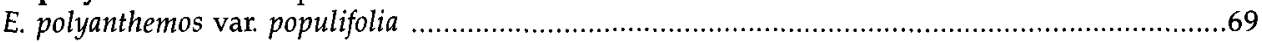

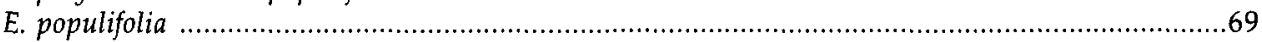

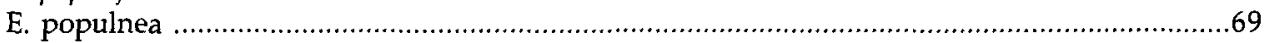

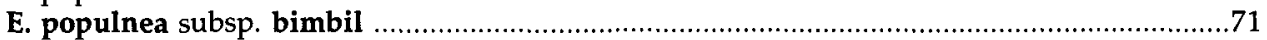

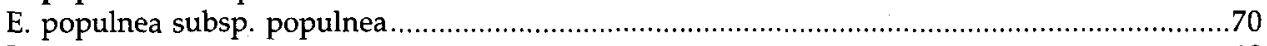

E. prava

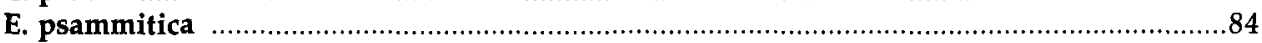

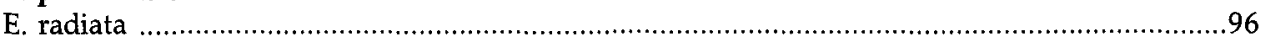

E. radiata subsp. radiata

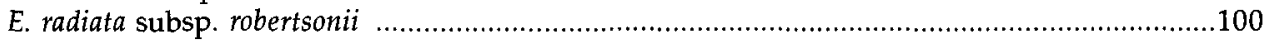

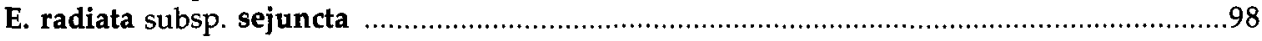

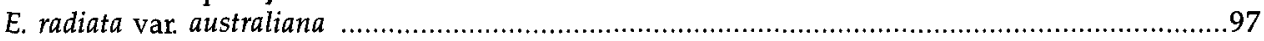

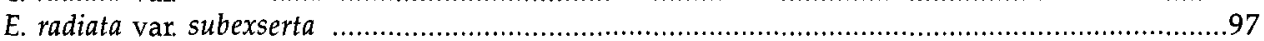

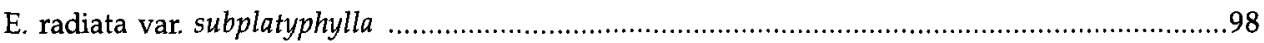

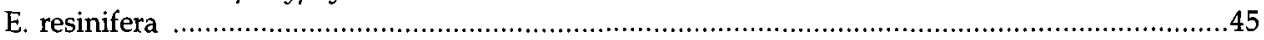

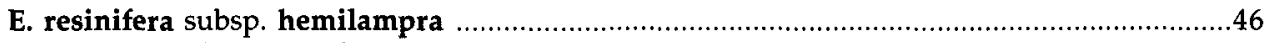

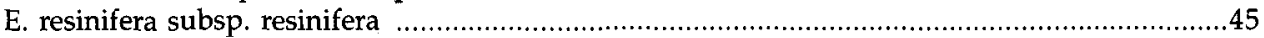

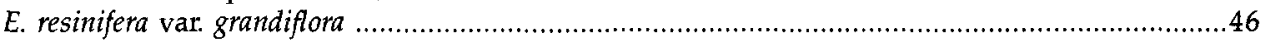

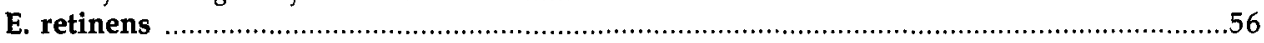

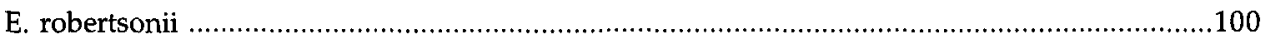

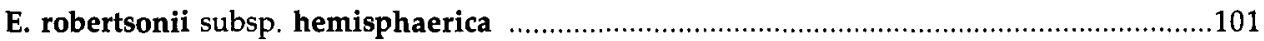

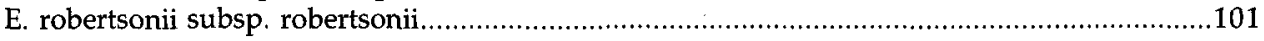

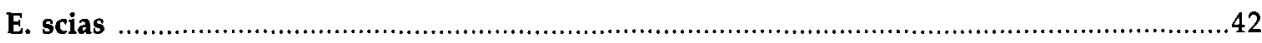

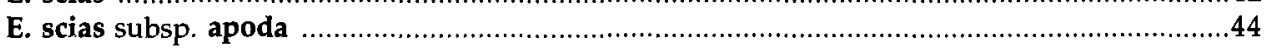

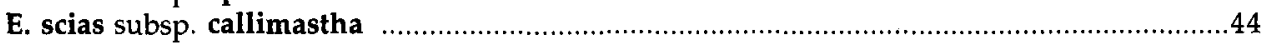

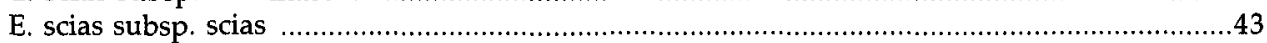

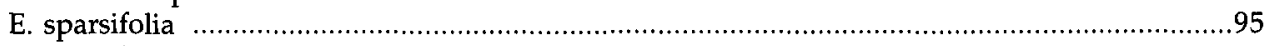

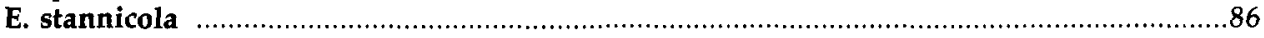

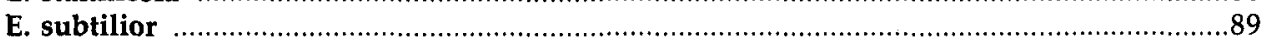

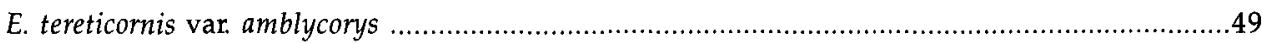

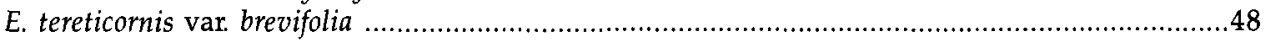

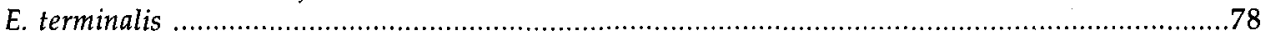

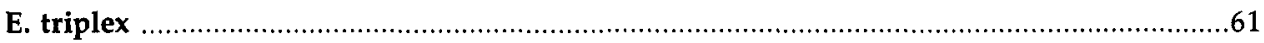

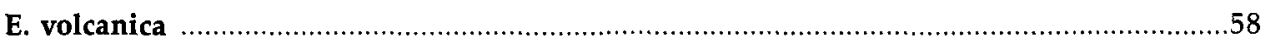

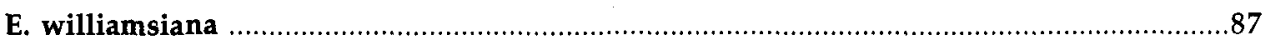

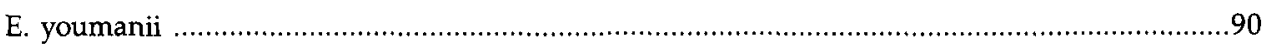

